
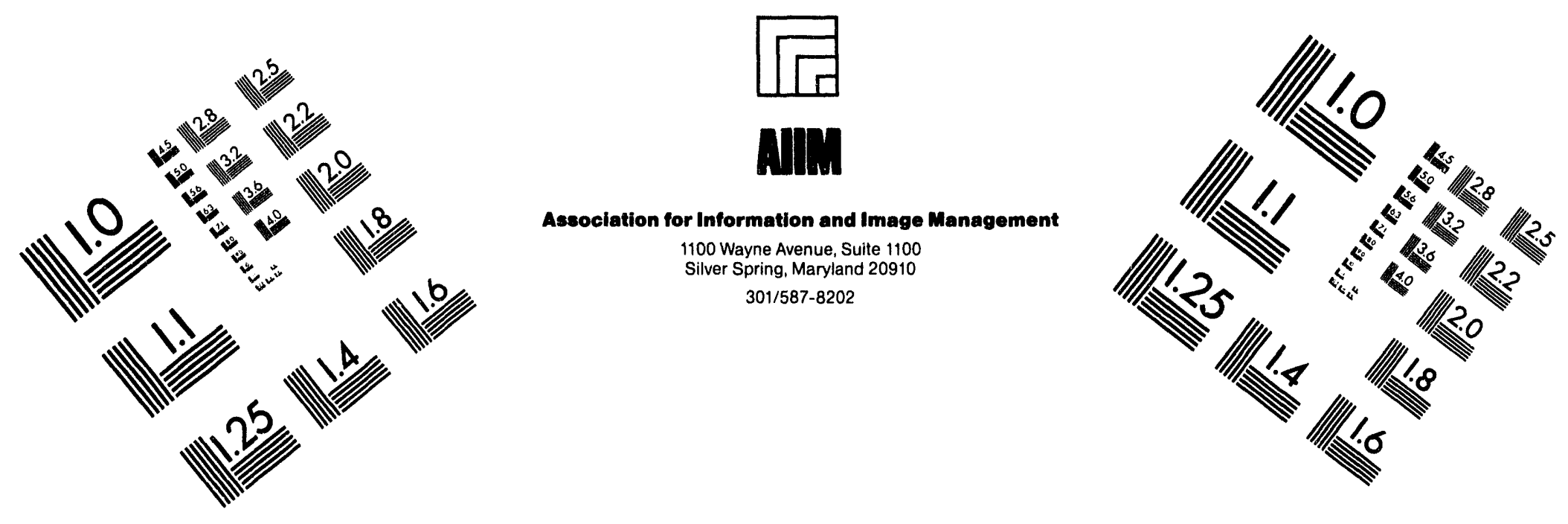

Centimeter

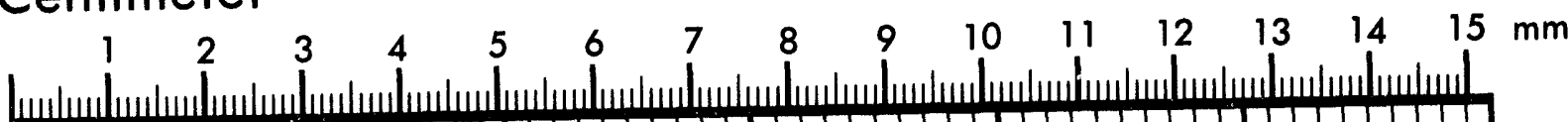

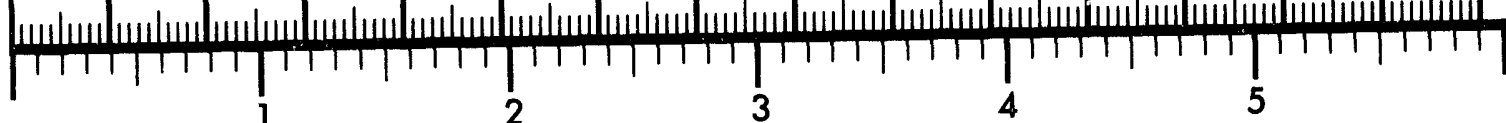
Inches
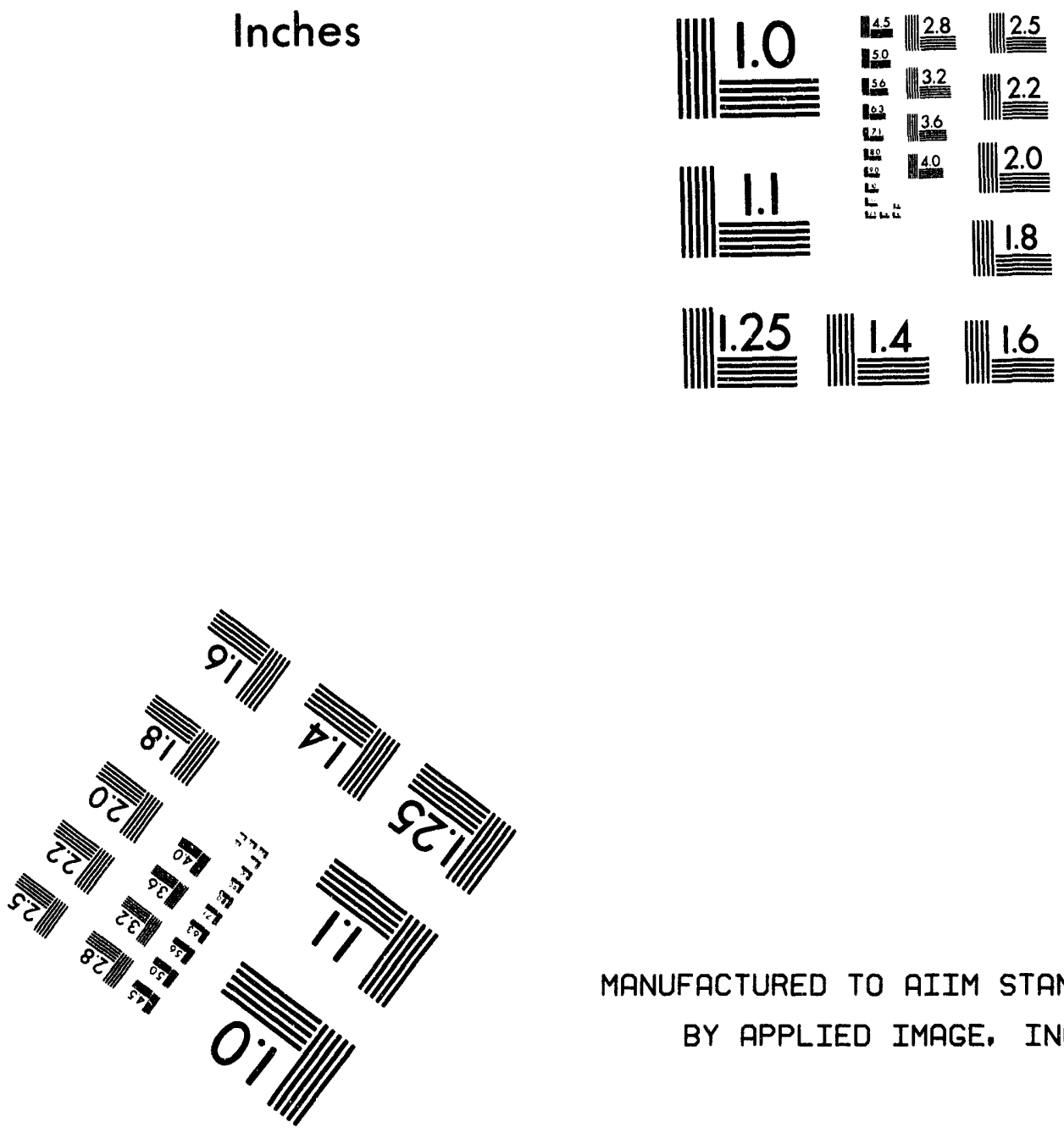

MANUFACTURED TO AIIM STANDARDS

BY APPLIED IMAGE, INC.

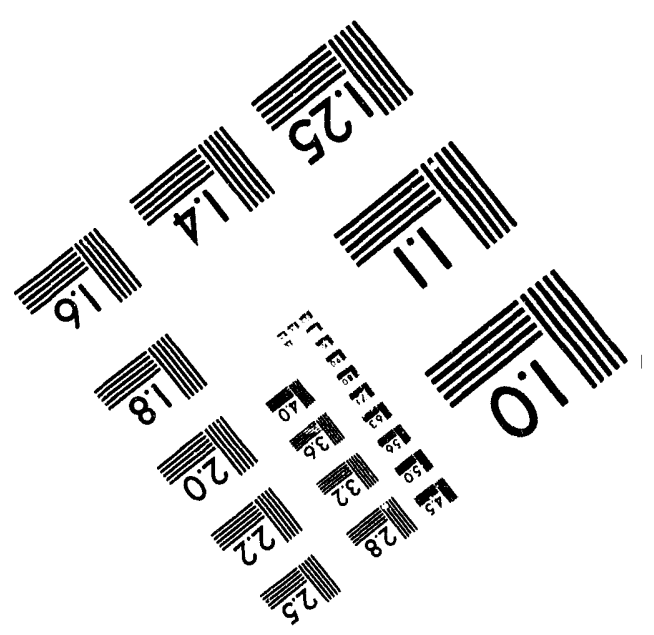



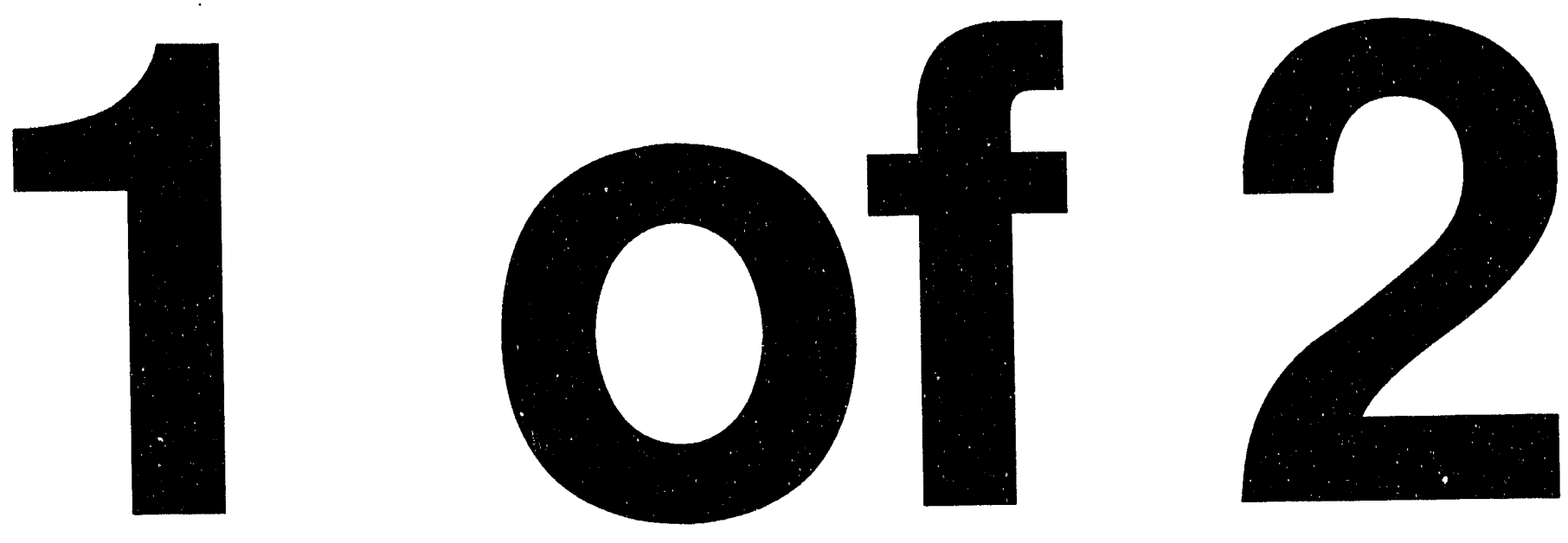


\section{Environmental Management}

\section{Pinellas Plant \\ Annual Site Environmental Report for Calendar Year 1993}
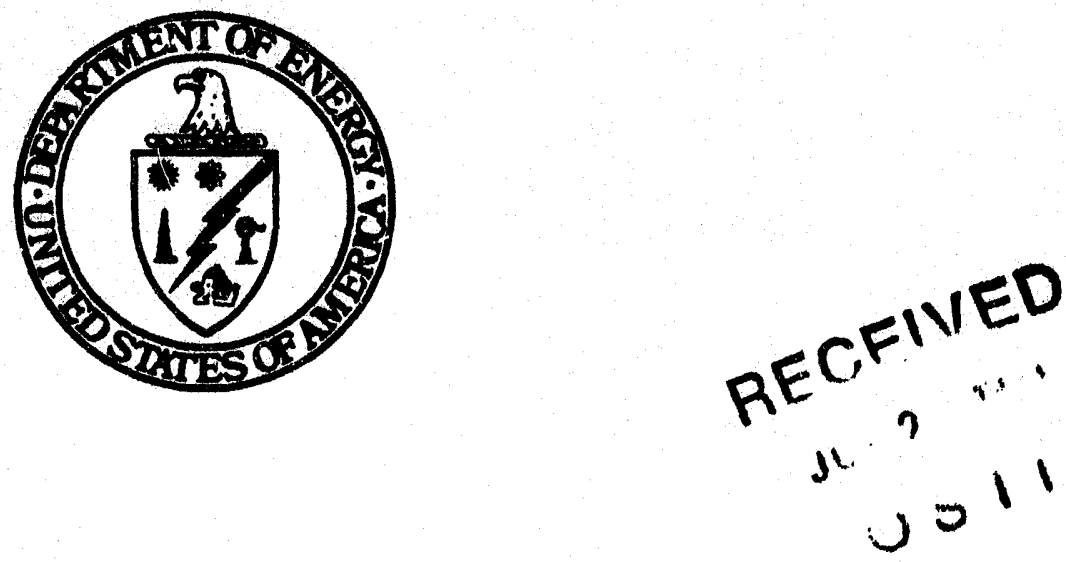

June 10, 1994

Martin Marietta Specialty Components, Inc., is the Management and Operating Contractor for the Pinellas Plant Under

U. S. Department of Energy Contract No. DE-AC04-92AL73000. 
Title: $\quad$ Pinellas Plant Annual Site Environmental Report for Calendar Year 1993

Number: $\quad$ MMSC-EM-94146

lasue Date: June 10, 1994

\section{DOCUMENT CONTROL}

This document will be maintained by Technical Support in accordance with the sitewide document control procedures. Document control elements include unique issue numbers, document identification, numbered pages, document distribution records, tracking of revisions, a document MASTER filing and retrieval system, and a document achieving system.

Martin Marietta Specialty Components, Inc.

P. O. Box 2908 Largo, FL 34649-2908

Management and Operating Contractor for the

Pinellas Plant under U. S. Department of Energy

Contract No. DE-ACO4-92AL73000 
This page left blank intentionally. 
DOCUMENT APPROVALS

Martin Marietta Specialty Components, Inc. Approval:

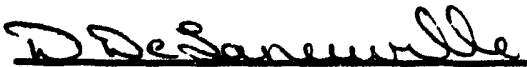

D. Delaneuville, Manager

Waste Management/Minimization

carly aresedemon

C. A. Biedermann, Manager

Environmental Restoration and Permitting

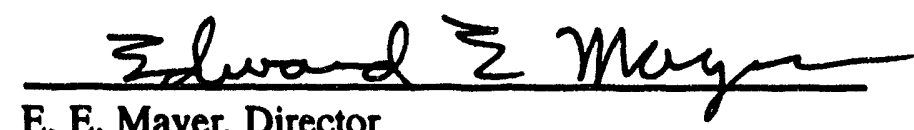

E. E. Mayer, Director Environmental Management

Department of Energy/Pinellas Area Once Approval:

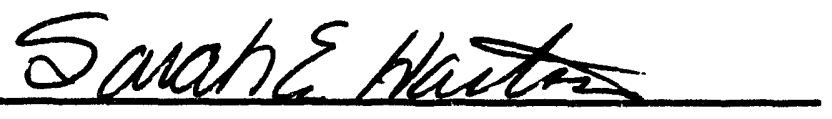

Sarah Hartson

Environmental Compliance Engineer

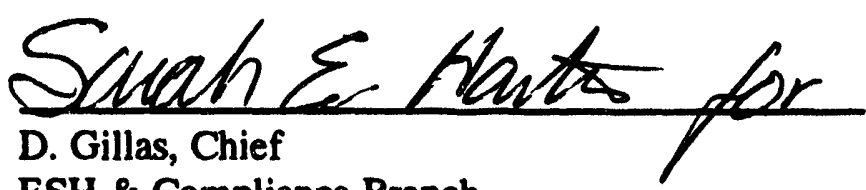

ESH \& Compliance Branch

REVIEWED FOR CLASSIFIED:

Tenrec

Classification Officen/Analyst/Derivative Classifier

UNCCSSSIALED

Classification Level
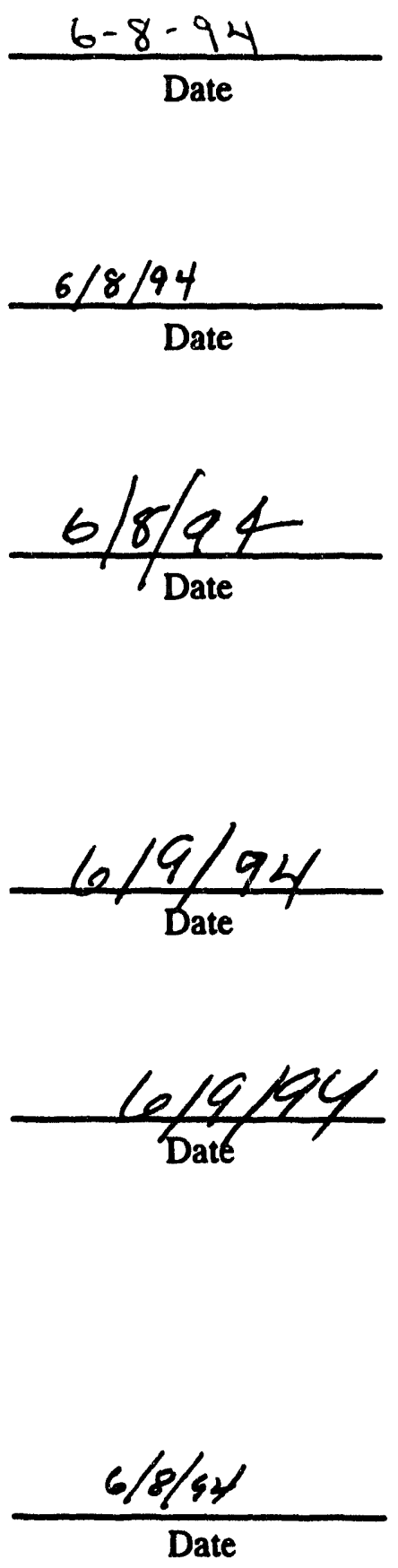

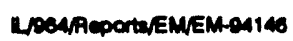

iii 
This page left blank intentionally. 


\section{ACRONYMS}

AAC ........... Acceptable Ambient Concentration

ADM ........... Action Description Memorandum

AHERA ......... Asbestos Hazard Emergency Response Action

AL $\ldots \ldots \ldots \ldots$....... Albuquerque Operations Office

ALARA .......... As Low As Reasonably Achievable

ASTM .......... American Society for Testing and Materials

BDL ........... Below Detection Limit

BOD ........... Biochemical Oxygen Demand

Bq ............. Becquerel

BTU ............ British Thermal Unit

CAA ........... Clean Air Act

CAR ........... Contamination Assessment Report

CEARP ......... Comprehensive Environmental Assessment and Response Program

CERCLA ......... Comprehensive Env. Response Compensation \& Liability Act

CFC ............ Chlorofluorocarbon

CFR ............ Code of Federal Regulations

Ci $\ldots \ldots \ldots \ldots \ldots$ Curie

CMTS .......... Chemical Material Tracking System

CMS ........... Corrective Measure Studies

COD ........... Chemical Oxygen Demand

CWA ........... Clean Water Act

CY $\ldots \ldots \ldots \ldots$ Calendar Year

CX ............. Categorical Exclusion

DCG ........... Derived Concentration Guides

DOE ........... Department of Energy

DOT ........... Department of Transportation

EA $\ldots \ldots \ldots \ldots \ldots$ Environmental Assessment

EML .......... Environmental Measurements Laboratory

EPA $\ldots \ldots \ldots \ldots$ Environmental Protection Agency

EPCRA .......... Emergency Planning and Community Right to Know Act

ESA $\ldots \ldots \ldots \ldots$ Endangered Species Act

ES\&H ......... Environmental Safety \& Health

ER $\ldots \ldots \ldots \ldots$. Environmental Restoration

FAC ........... Florida Administrative Code

FDEP .......... Florida Department of Environmental Protection

FIFRA ......... Federal Insecticide, Fungicide, and Rodenticide Act

FONSI ......... Finding of No Significant Impact

FY ............. Fiscal Year

GPMP .......... Groundwater Protection Management Program

GOP $\ldots \ldots \ldots \ldots$ General Operating Policy

HAPs .......... Hazardous Air Pollutants

HAZMAT ........ Hazardous Material Response Team

HRS .......... State of Florida Dept. of Health and Rehabilitative Services 


\section{ACRONYMS (CONTINUED)}

HSWA $\ldots \ldots \ldots$ Hazardous and Solid Waste Amendments

ICM $\ldots \ldots \ldots \ldots$.... Interim Corrective Measure

IRA ........... Interim Remedial Action

ITRD .......... Innovative Treatment Remediation Demonstration

IWNF .......... Industrial Wastewater Neutralization Facility

LDR ........... Land Disposal Restriction

LLMW ......... Low Level Mixed Waste

LLW ........... Low Level Waste

MAC ........... Maximum Ambient Concentrations

MCL ............ Maximum Contaminant Level

MDL ........... Method Detection Limit

ml ............. Mililiter

MSL ............ Mean Sea Level

NDL .......... New Directions in Learning Child Development and Partnership School

NEPA .......... National Environmental Policy Act

NESHAP ........ National Emission Standards for Hazardous Air Pollutants

NHPA ......... National Historic Preservation Act

NOD ........... Notice of Deficiency

NOTI .......... Notice of Technical Inadequacy

NPDES ......... National Pollutant Discharge Elimination System

NTL .......... No-Threat-Level

NTS ............ Nevada Test Site

O\&M ........... Operations and Maintenance

OC ............ Organic Compound

OSHA .......... Occupational Safety and Health Administration

PAH $\ldots \ldots \ldots \ldots$. Polyaromatic Hydrocarbons

PAO ............ Pinellas Area Office

PCAQD .......... Pinellas County Air Quality Division

PCB ............ Polychlorinated Biphenyl

PCSS ........... Pinellas County Sewer System

PCWS .......... Pinellas County Water System

P.E.T. ........... Proficiency Testing Program

PMT ........... Performance Management Team

ppb ........... Parts Per Billion

ppm ........... Parts Per Million

POTW .......... Publicly Owned Treatment Works

PRP ............ Potentially Responsible Party

QA ............ Quality Assurance

QAPP .......... Quality Assurance Program Plan

QC ............ Quality Control

QPP .......... Quality Program Plan

RCRA .......... Resource Conservation and Recovery Act

RFA $\ldots \ldots \ldots \ldots$ RCRA Facility Assessment

RFI ........... RCRA Facility Investigation

RQ $\ldots \ldots \ldots \ldots$ Reportable Quantity 


\section{ACRONYMS (CONTINUED)}

RMMA ......... Radioactive Materials Management Area

RTG ........... Radioisotopically Powered Thermoelectric Generator

SARA ........... Superfund Amendment and Reauthorization Act

SDWA .......... Safe Drinking Water Act

SI ............ International System of Units

SPCC ........... Spill Prevention, Control and Countermeasures Plan

Sv ............. Sievert

SWMU .......... Solid Waste Management Unit

TCLP .......... Toxicity Characteristic Leaching Procedure

TOC ............ Total Organic Carbon

TSCA .......... Toxic Substances Control Act

TRS ........... Tritium Recovery System

TSA $\ldots \ldots \ldots \ldots$ Technical Safety Appraisal

TSS ........... Total Suspended Solids

TTO ............ Total Toxic Organic

USGS ........... United States Geological Survey

UST $\ldots \ldots \ldots \ldots$ Underground Storage Tank

$\mu \mathrm{Ci} \ldots \ldots \ldots \ldots \ldots$ Microcuries

VOC ........... Volatile Organic Compound

WM $\ldots \ldots \ldots \ldots$ Waste Management 
This page left blank intentionally. 


\section{TABLE OF CONTENTS}

Section

Page

EXECUTIVE SUMMARY 1

1.0 INTRODUCTION $1-1$

1.1 Site and Installation Description $1-1$

1.2 Climatology $1-3$

1.3 Weather and Air Pollution $1-4$

1.4 Seismology $1-12$

1.5 Land Use $1-14$

1.6 Population $1-16$

$\begin{array}{lll}1.7 \text { Water } & 1-17\end{array}$

2.0 COMPLIANCE SUMMARY $2-1$

2.1 Compliance Status $2-1$

2.1.1 Clean Air Act 2-1

2.1.2 Clean Water Act 2-2

2.1.3 Safe Drinking Water Act 2-4

2.1.4 Resource Conservation and Recovery Act $2-4$

2.1.5 Comprehensive Environmental Response, Compensation, 2-6 and Liability Act

2.1.6 Nationel Environmental Policy Act 2-6

2.1.7 Toxic Substances Control Act 2-7

2.1.8 Federal Insecticide, Fungicide and Rodenticide Act $2-7$

2.1.9 Endangered Species Act 2-7

2.1.10 National Historic Preservation Act $\quad 2.7$

2.1.11 Executive Order 11988, "Floodplain Management" 2-7

2.1.12 Executive Order 11990, "Protection of Wetlands"

2.1.13 Emergency Planning and Community Right to Know 2-8 Action of 1986

2.2 Other Major Environmental Issues and Actions $2-8$

2.2.1 Tiger Team Assessment of the Pinellas Plant, January 1990

2.2.2 Technical Safety Appraisal of the Pinellas Plant, February $1992 \quad 2-11$

2.2.3 Technical Safety Appraisal of the Pinellas Plant, March $1993 \quad 2-11$ 


\section{TABLE OF CONTENTS (CONTINUED)}

Section

2.3 Summary of Permits

$\begin{array}{ll}\text { 2.3.1 RCRA Permit } & 2-11\end{array}$

2.3.2 Industrial Wastewater Dischargo Permit $\quad 2-12$

$\begin{array}{ll}\text { 2.3.3 Stormwater Discharge Permit } & 2-12\end{array}$

$\begin{array}{lr}\text { 2.3.4 Air Emissions Pormit } & 2-12\end{array}$

3.0 ENVIRONMENTAL PROGRAM INFORMATION 3-1

3.1 Environmental Monitoring Summary 3-1

3.1.1 Nonradiological Monitoring 3-1

3.1.2 Radiological Monitoring 3-3

3.1.3 Groundwater Quality $3-6$

3.2 Compliance with the NEPA 3-7

3.3 Significant Environmental Activities 3-11

3.3.1 Pollution Abatement $3-11$

3.3.2 Special Studies 3-13

3.4 Assessments 3-13

3.5 Pollution Prevention and Waste Minimization 3-14

$\begin{array}{ll}3.6 & \text { Reports and Certifications } \\ 3.7-15\end{array}$

3.7 Training

4.0 ENVIRONMENTAL RADIOLOGICAL PROGRAM INFORMATION 4-1

4.1 Radiation Dose Terminology and Dose Standards 4-1

4.2 Radioactive Effluent Data 4-2

$\begin{array}{lll}\text { 4.2.1 Air } & 42\end{array}$

$\begin{array}{ll}4.2 .2 \text { Water } & 45\end{array}$

4.3 Environmental Sampling for Radioactivity 4-6

$\begin{array}{lll}\text { 4.3.1 Air } & 46\end{array}$

$\begin{array}{ll}\text { 4.3.2 Water } & 49\end{array}$

$\begin{array}{ll}4.3 .3 \text { Soil } & 4-12\end{array}$

4.4 Evaluation of Potential Dose to the Public 4-15

$\begin{array}{ll}\text { 4.4.1 Dose Standards } & \text { 4-15 }\end{array}$

4.4.2 Dose th the Public Due to Naturally Occurring Radiation 4-15

4.4.3 Potentia I Dose to the Population Within 50 Miles of the Plant Site 4-16

4.4.4 Potenti: I Dose to the Most Exposed Member of the Public 416

$\begin{array}{ll}\text { 4.4.5 Potential Dose Due to Plutonium } & \text { 4-17 }\end{array}$

$\begin{array}{lr}\text { 4.4.6 Minor Source Compliance } & \text { 4-17 }\end{array}$ 


\section{TABLE OF CONTENTS (CONTINUED)}

Section

4.5 Unplanned Releases and Environmental Occurrences 4-18

$\begin{array}{ll}\text { 4.6 ALARA Program } & \text { 4-18 }\end{array}$

5.0 ENVIRONMENTAL NONRADIOLOGICAL PROGRAM INFORMATION 5-1

5.1 Atmospheric Nonradiological Emissions 5-1

5.2 Water $5-2$

5.2.1 Wastewater 5-2

5.2.2 Surface Water $\quad 5-6$

$\begin{array}{ll}5.2 .3 \text { Stormwater } & 5-6\end{array}$

5.3 Environmental Occurrences $5-6$

5.4 SARA Title III Reporting 5-6

5.5 Continuous Release Reporting 5-7

6.0 GROUNDWATER PROTECTION PROGRAM 6-1

6.1 Introduction 6-1

6.2 Description of the Groundwater Monitoring Program 6-2

6.3 Hydrogeology 6-3

6.4 Description and Groundwater Results of Areas of Potential 6-5

Environmental Concern

6.4.1 Procedures and Results $6-12$

6.4.2 Floridan Aquifer $\quad 6-15$

6.4.3 Perimeter Survellance Network 6-16

6.4.4 4.5 Acre Site 6-16

6.4.5 Solid Waste Management Units $\quad 6-22$

7.0 QUALITY ASSURANCE

$\begin{array}{ll}7.1 & \text { Nonradioactive Effluent } \\ 7.2 & \text { 7-2 }\end{array}$

7.2 Radioactive Effluent and Monitoring 7-3

7.3 Data Management $7-4$

7.4 Proficiency Testing Programs $7-4$

$\begin{array}{ll}\text { 7.5 QA Program for Meteorology Station } & \mathbf{7 - 8}\end{array}$

$\begin{array}{lll}7.6 & \text { Audit Program } & \mathbf{7 - 8}\end{array}$

8.0 REFERENCES $\quad$ 8-1

$\begin{array}{lll}9.0 & \text { DISTRIBUTION } & \text { 9-1 }\end{array}$ 


\section{TABLE OF CONTENTS (CONTINUED)}

\section{ILLUSTRATIONS}

Number

1-1 State of Florida Map

1-2 Pinellas County Map

1-3 January 1993 Pinellas Plant Wind Rose

1-4 July 1993 Pinellas Plant Wind Rose

1-5 Pinellas Plant 1993 Annual Wind Rose

1-5 Seismic Risk Map of the United States

1-7 Pinellas Plant Site Layout

3-1 Regulated Liquid Effluent Releases Above Detectable Limit, 1993

4-1 On-Site Exhaust Stack and Ambient Air Sampling Station Locations

4-2 Tritium Stack Emissions, 1993

4-3 Off-Site Air Sampling Station Locations

4-4 Off-Site Surface Water Sampling Locations

4-5 On-Site Soil Sampling Locations

4-6 Off-Site Soil Sampling Locations

5-1 Pinellas Plant Actual 1993 VOC/OC Emissions

5-2 Nonradiological Liquid Effluent Sampling Locations

6-1 Generalized Geologic Cross Section in the Vicinity of the Pinellas Plant

6-2 Water Table Map - January 1993

6-3 Water Table Map - April 1993

6-4 Water Table Map - July 1993

6-5 Water Table Map - October 1993

6-6 Potentiometric Surface of the Upper Floridan Aquifer, September 1992

6-7 Location of Perimeter Groundwater Monitoring Wells

6-8 Location of Groundwater Monitoring Wells, Piezocone and Hydrocone Sampling 6-19

6-9 Chemical Time Series Graph - Monitoring Well 4.5 MW-18

6-10 Chemical Time Series Graph - Monitoring Well 4.5 MW-20

6-11 Chemical Time Series Graph - Monitoring Well 4.5 MW-27 


\section{ILLUSTRATIONS (CONTINUED)}

Number

6-13 Regulatory Steps of Remediation

6-14 Chemical Time Series Graph - Monitoring Well NE MW-2D

6-15 Chemical Time Series Graph - Monitoring Well NE MW-21

6-16 Chemical Time Series Graph-Monitoring Well NE MW-2S

6-17 Chemical Time Series Graph-Monitoring Well NE MW-3

6-18 Chemical Time Series Graph - Monitoring Well NE MW-4

6-19 Recovery of VOCs in Pinellas Plant Groundwater Treatment System Since May 1990

\section{TABLES}

Number

1-1 Pinellas Plant Meteorological Station Wind Frequency Distribution, 1993, by Wind Speed, Stability Class, and Origin

1-2 1993 Monthly Statistical Summaries of Pinellas Plant Meteorological Monitoring Station

1-3 Pinellas County Population Statistics

1-4 1990 Population by Sector-Segment

3-1 Summary of Air Environmental Monitoring at the Pinellas Plant in 1993

3-2 Summary of Total Radiological Stack Emission (Tritium and Krypton) for 1993

3-3 Tritium Discharged to PCSS, 1993

3-4 Groundwater Monitoring Summary

3-5 NEPA Documentation as of December 31, 1993

4-1 1993 Stack Releases to the Atmosphere

4-2 Tritium Released in the Combined Wastestream to the PCSS in 1993

4-3 1993 On-Site Ambient Air Sampling Results

4-4 1993 Off-Site Ambient Air Sampling Results

4-5 On-Site Surface Water Tritium Concentrations

4-6 Soil Sample Location Schedule

4-7 1993 Dose to the Most Exposed Individual 


\section{TABLES (CONTINUED)}

Number

Page

5-1 1993 Actual Emissions

5-1

5-2 Combined Nonradiological Liquid Effluent Analysis Results

$5-4$

5-3 PCSS and Pinellas Plant Wastewater Split Sample Comparison

5-5

5-4 Report of Pinellas Plant's Compounds for Calendar Year 1993

6-1 Pinellas Plant Groundwater Monitoring Program

6-3

6-2 Tritium Groundwater Sample Concentrations

6-3 Metal Groundwater Sample Concentrations

6-4 VOC Groundwater Sample Concentrations

6-12

6-5 Pinellas Plant Groundwater Elevation Data

6-6 4.5 Acre Site Historic High Versus Current High

6-7 Pinellas Plant SWMUs

7-1 Wastewater Sampling Schedule

7-2 QA Sample Frequency Requirements

7-3 Third-Party Quality Assurance Program Summary

7-4 1993 Results of Analysis of Spiked Samples Provided by Government Third-Party Quality Assurance Programs

7-5 1993 Results, Commercial Third-Party Quality Assurance Program 


\section{EXECUTIVE SUMMARY}

Martin Marietta Specialty Components, Inc., and the U.S. Department of Energy are committed to successfully administering a high quality Environmental Management Program at the Pinellas Plant in Pinellas County, Florida. Part of this commitment includes accurately documenting and communicating to the Pinellas Plant stakeholder the results of their environmental compliance and monitoring activities. The Annual Site Environmental Report presents a comprehensive summary of the results of the environmental monitoring, waste management, and environmental restoration programs at the Pinellas Plant for 1993. This report also includes the plant's performance in the areas of compliance with applicable regulatory requirements and standards and identifies major environmental management program initiatives and accomplishments for 1993. This report satisfies the requirements specified in DOE 5400.1, General Environmental Protection Program and DOE 5484.1, Environmental Protection, Safety, and Health Protection Information Reporting Requirements. The major sections of the Annual Site Environmental Report are summarized below:

\section{COMPLIANCE SUMMARY}

In 1993, the Pinellas Plant operated within applicable regulatory limits for both radiological and nonradiological discharges to the air and water. Periodic confirmatory measurements by oversight regulatory agencies verified the compliance status.

Florida Department of Environmental Protection inspectors found three "minor violations" during a site inspection, two open containers in a satellite accumulation area and one for an improper label. All three violations were corrected immediately. During a second inspection, the plant was cited for two "potential violations" involving storage of liquid waste and lack of a contingent post-closure plan. All issues are actively being addressed.

The plant submitted a hazardous waste operating permit renewal application to the Florida Department of Environmental Protection in April 1993, and responded to all comments in a Notice of Deficiency that was received in July 1993. A renewed hazardous waste operating permit is anticipated in 1994.

The plant received final approval of the Resource Conservation Recovery Act Facility Investigation Report from the Environmental Protection Agency in February 1993. The report recommended corrective measures for four Solid Waste Management Units and no further action on 12 others. Innovative cleanup technologies investigated for feasibility in 1994 may accelerate cleanup at these Solid Waste Mrnagement Units.

An inspection by Pinellas County Sewer System personnel resulted in no non-compliances. The Pinellas Plant initiated discussions with Pinellas County Sewer System personnel on potential impacts to the existing wastewater discharge permit due to the end of defense related production in September 1994 and the subsequent economic development at the plant. Initially, new business wastewater discharges will be regulated under existing Department of Energy permits. The Pinellas County Sewer System, working closely with the Pinellas Plant environmental compliance personnel, will evaluate the need for permit modifications on a case-by-case basis. 
On January 7,1993 , the plant received an air pollution source construction permit from the Florida Department of Environmental Protection, regulating plantwide nonradiological air emissions. The plant completed operations plans, data collections and certifications and pending a regulatory review, anticipates issuance of a 5-year Operating Permit in early 1994.

Significant National Environmental Policy Act activities in 1993 included two Environmental Assessments; one for consolidation of plant defense related production and one for commercialization of plant facilities and buildings. The U.S. Department of Energy Headquarters, Washington, D.C., granted the plant a categorical exclusion from further National Environmental Policy Act review for the consolidation environmental assessment. A decision on the commercialization environmental assessment is expected in 1994.

The Department of Energy conducted a Technical Safety Appraisal at the Pinellas Plant in March 1993. The appraisal included environmental monitoring, emergency response, spill prevention, National Environmental Policy Act, and waste minimization. The plant received a "superior" rating which is the best possible rating.

\section{ENVIRONMENTAL PROGRAM}

The basis for the Environmental Monitoring Program is identified in the Pinellas Plant Environmental Monitoring Plan. The plan establishes a monitoring program specifically designed to detect radiological and nonradiological releases to the air, soil, surface waters, and groundwater and to determine the potential impacts to the public and environment. Trends in environmental data are monitored to verify progress of contaminated site cleanup and early warning so that corrective actions can be implemented prior to exceeding regulatory standards. All monitoring is in accordance with approved procedures. These procedures are reviewed regularly and updated to incorporate the latest technical and regulatory developments.

\section{Environmental Radiological Monitoring Program}

Radiological releases at the plant occur through the air and industrial wastewater discharge pathways. The Environmental Radiological Monitoring Program includes wastewater, exhaust stack, on- and off-site air, surface water and soil sampling.

In 1993, the air monitoring program included continuous sampling of six exhaust stacks and seven on-site and six off-site sampling stations. Between 1975 and 1991, the Radioisotopicallypowered Thermoelectric Generator product was manufactured at the Pinellas Plant which utilized a small triply-sealed plutonium heat source. All plutonium heat sources were carefully controlled and removed from the site by February 1991. The plutonium material was never processed at the Pinellas Plant, but was merely inserted in its as-received triply-sealed form into the product. The Environmental Radiological Monitoring Program analyzes air and soil samples to confirm there was never a release of plutonium. No plutonium was detected from past manufacture. Tritium and krypton- 85 releases continue to be well below standards set by the Department of Energy and the Environmental Protection Agency. During 1993, the plant released a total of 11.6 curies of tritium and 18.7 curies of krypton-85 into the atmosphere. The 1993 releases were well below the previous year's releases. Effective process control and a diminished workload contributed to the reduction. The estimated dose to the population within a 
50-mile radius of the plant in 1993 was estimated by the CAP88-PC computer code to be 4.3E-02 (0.043) person-rem/yr. The calculated dose to the most exposed individual was also estimated by CAP88-PC to be 2.3E-03 (0.0023) $\mathrm{mrem} / \mathrm{yr}$, which is well below the Environmental Protection Agency and the Department of Energy standards of $10 \mathrm{mrem} / \mathrm{yr}$.

The Environmental Monitoring Program includes sampling of the industrial wastewater discharges and on- and off-site surface water. Pinellas Plant monitoring personnel collected surface water samples from three on-site ponds and twenty-six off-site ponds, ditches, and lakes and analyzed them for tritium. Ninety-three percent of the on-site pond samples and all of the off-site samples were below the analytical detection limits for tritium. Where tritium was detected, the concentrations were below drinking water standards. All water and wastewater samples were well below regulatory standards and health-based limits for radionuclides. All soil samples collected showed no traces of plutonium from previous plant operations.

\section{Environmental Nonradiological Monitorine Propram}

Nonradiological releases at the plant occur through the industrial wastewater discharge and air pathways. The Nonradiological Monitoring Program includes routine sampling of industrial wastewater and periodic confirmatory sampling of fenceline ambient air concentrations.

Specialty Components Environmental Management personnel sampled the industrial wasteivater discharge and analyzed it for pollutants identified in the plant wastewater discharge permit. Analyses are performed for metals (e.g., lead, mercury and cadmium), total suspended solids, biochemical oxygen demand, and total toxic organics. The pH is monitored continuously. Releases of regulated pollutants in 1993 were at consistently low levels and well below regulatory limits.

The Pinellas Plant compliance with fenceline ambient air concentrations in 1993 was below regulatory limits using air dispersion computer models. Specialty Components Environmental Management personnel sampled ambient air concentrations in November 1993, to confirm the computer modeling results. This sampling verified that fenceline concentrations were below regulatory limits for volatile organic compounds and chloroflorocarbon compounds and confirmed accuracy of modeling that was conducted during the permitting effort.

\section{Groundwater Protection}

Specialty Components Environmental Management personnel administer the Groundwater Protection Management Program at the Pinellas Plant. This program's objectives include the following: to monitor groundwater to demonstrate compliance with applicable regulations, to provide data to permit early detection of contamination, and to determine effectiveness of groundwater cleanup actions.

During 1993, approximately 1500 groundwater samples were collected from 150 monitoring wells. The results indicate groundwater contamination is limited to isolated areas of the on-site shallow surficial aquifer and no contamination occurred in the deep drinking water aquifer. The primary contaminants of concern are common industrial solvents, such as trichloroethene and methylene chloride. Groundwater recovery and subsequent treatment continue to successfully reduce contaminant concentrations. 


\section{QUALITY ASSURANCE}

The Quality Assurance Program for environmental monitoring is documented in the Quality Program Plan for Environmental Monitoring, MMSC-QPP-0028. This plan is written to meet the requirements of DOE 5700.6, Quality Assurance, and identifies specific requirements for the management, performance, assessment and continuous improvement of environmental monitoring. This plan provides a systematic approach to environmental monitoring and establishes a program to ensure regulatory requirements are n-et. This plan is also consistent with and supplemented by the Quality Program Plan for Environmental, Safety, and Health programs, MMSC-QPP-0033. 


\subsection{INTRODUCTION}

The 1993 Pinellas Plant Annual Site Environmental Report presents, in summary form environmental data that characterizes the performance of site environmental management efforts, confirms compliance with environmental standards and requirements, and highlights significant programs and efforts. It presents summary data for the Environmental Monitoring Program which is conducted in accordance with the Pinellas Plant Environmental Monitoring Plan [Ref. 1].

Specialty Components Environmental Management used the following documents in preparing this report:

- DOE 5400.1, General Environmental Protection, June 1990 [Ref. 2]

- DOE 5400.5, Radiation Protection of the Public and the Environment, February 1990 [Ref. 3].

- DOE 5484.1, Environmental Protection, Safety and Health Protection Information Reporting Requirements, October 1990 [Ref. 4].

- Final Guidance for the Preparation of Annual Site Environmental Reports for Calendar Year 1993, EH-22, February 10, 1994.

\subsection{Site and Installation Description}

The Pinellas Plant is owned by the United States Department of Energy (DOE) and operated by Martin Marietta Specialty Components, Inc. (Specialty Components). The contract is administered by the DOE Albuquerque Operations Office (AL) through the DOE Pinellas Area Office (PAO). The plant has been an essential part of the nation's Nuclear Weapon Complex, but is scheduled to stop production of weapons-related components late in 1994.

The plant's mission is small-volume production of selected high-technology nuclear weapon components that require strict control of materials and processes in an ultra-clean environment. These conditions were imposed by the plant's first assignment, the development of neutron generators, used as external initiators of nuclear weapons. The plant's product line has expanded to include lightning arrestor connectors, capacitors, magnetics, optoelectronic devices, and other similar components. Some of these product lines are now being investigated for conversion to commercial and nonmilitary applications.

The plant employs approximately 1150 employees, about 500 employees less than previous years, as a result of the reduction in force that occurred between October and December 1992. The PAO has approximately 30 employees. The plant area has expanded to over 700,000 square feet from its 1957 beginnings at about 160,000 square feet. Its structures and paved areas occupy about $35 \%$ of the 99-acre site, the rest of which is open space. The site is bordered on the north by light industrial and vacant land, on the east by Belcher Road (County Road 135), on the west by CSX railroad tracks, and on the south by Bryan Dairy Road. 
The Pinellas Plant is located in Pinellas County, Florida (Figures 1-1, 1-2), between the cities of Clearwater and St. Petersburg. Originally constructed in an isolated area, the plant site today is surrounded by light industrial and residential areas. The closest residential area is approximately 0.5 kilometer, or 0.3 miles, from the plant. The open space of the site includes two stormwater retention ponds, East Pond and South Pond, and one stormwater detention pond, the West Pond. The total area of these surface waters is approximately five acres.

Manufacturing operations fall into the metal finishing category, as defined by the Environmental Protection Agency (EPA). Manufacturing processes include electroplating, electroless plating, encapsulation, etching and chemical cleaning, machining, grinding, burnishing, impact deformation, shearing, thermal cutting, welding, brazing, soldering, flame spraying, sand blasting, degreasing, painting, calibration, and testing. This work involves handling small quantities of tritium and krypton-85. During 1990, the Radioisotopically-powered Thermoelectric Generator (RTG) product line was discontinued. All RTG plutonium heat sources were carefully controlled and removed from the site by February 1991. As by-products of production, a variety of waste materials are generated and are carefully controlled by the plant and regulated by Federal, State, and local agencies.

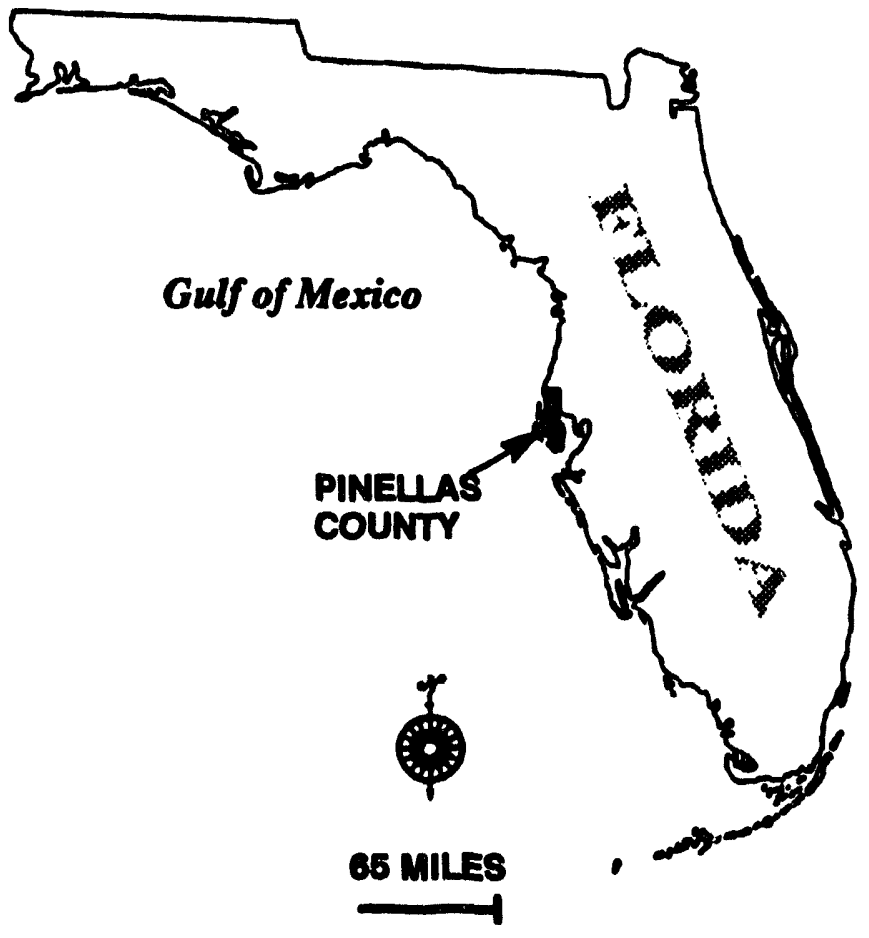

Figure 1-1. State of Florida Map 


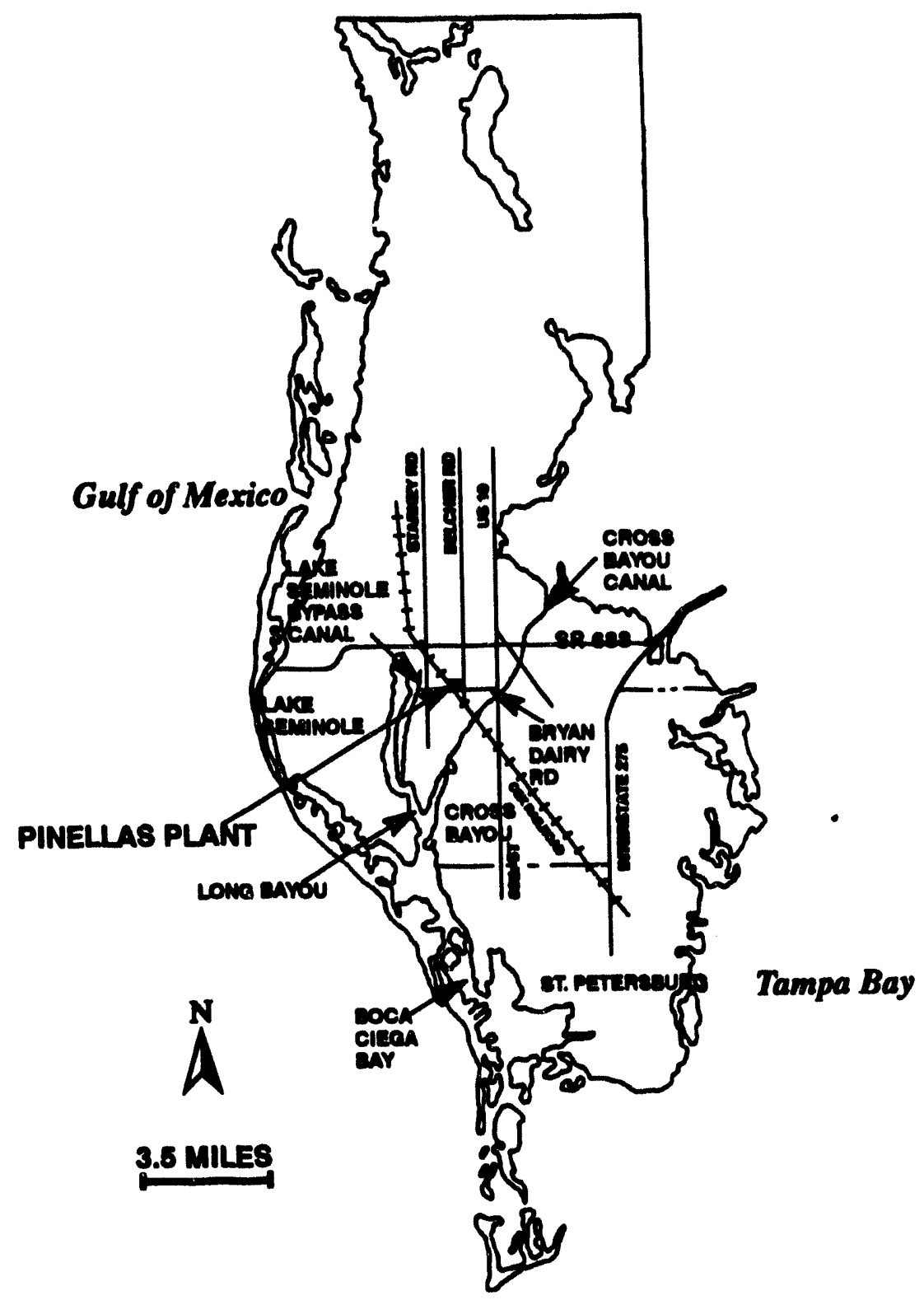

Figure 1-2. Pinellas County Map

\subsection{Climgtology}

The climate of the Tampa Bay area is characterized as subtropical, with the primary wet season during the summer and a secondary wet season during winter. Winters are generally mild, with summers being rather long, warm, and humid. Low temperatures average 50 degrees Fahrenheit in the winter and 70 degrees Fahrenheit in the summer. Afternoon highs range from the low 70 s in winter to around 95 degrees Fahrenheit from June through September. Invasions of cold northern air can produce an occasional cold winter morning. Freezing 
temperatures may occur several mornings a year during December, January, and February. In some years, no freezing temperatures are recorded. Snowfall is very rare.

One prominent feature of the Tampa Bay area's climate is the summer thunderstorm activity. The majority of these occur in the late afternoon hours from June through September. Sudden temperature drops of 15 to 20 degrees Fahrenheit are often associated with these events. The heaviest rains in a 24-hour period average 12 inches, and are associated with hurricanes. Hurricane season is from June 1 to November 30.

The Tampa Bay area is characterized by two distinct predominant wind patterns. During two-thirds of the year, regional wind patterns dictate meteorological conditions. These winds are generally from the north to northeast with a wind speed of five to seven miles per hour. This regional wind regime, with its predominant wind origin from the northeast, dominates the winter season. Coastal recirculation wind patterns also play a significant role in Tampa Bay's meteorology, and are characterized by the striking feature of a widely distributed wind direction across nearly all compass directions. The coastal recirculation wind patterns are more predominant during summer, and are closely associated with the summer thunderstorm activity experienced in the region. These two wind regimes are clearly demonstrated by a comparison of o1 -site wind data depicted in the wind roses for January and July 1993 (Figures 1-3 and 1-4). The composite wind rose for the entire year of 1993 is shown in Figure 1-5.

\subsection{Weather and Air Pollution}

Ambient air pollutant levels are dictated by the prevailing atmospheric conditions. The primary mechanisms which dictate pollutant dispersion and pollutant concentration levels are wind speed, direction, and atmospheric stability.

Atmospheric stability is defined as the relative ability of a parcel of air to move freely through the effects of mechanical and thermal turbulence, providing greater dilution and dispersion of pollutants. Combined with the various atmospheric stability characteristics of the local area, both the synoptic wind patterns and the coastal recirculation wind patterns play a significant role in determining pollutant levels in the region.

In August 1992, the Pinellas Plant began collecting meteorological data from its new meteorological monitoring station. The station monitors twenty parameters from 12.5- and 30-meter towers, monitors real-time local meteorological conditions, and enhances the Specialty Components Environmental Management Division pollutant modeling. With the on-site station, the plant can provide a detailed characterization of local weather conditions throughout the year. 


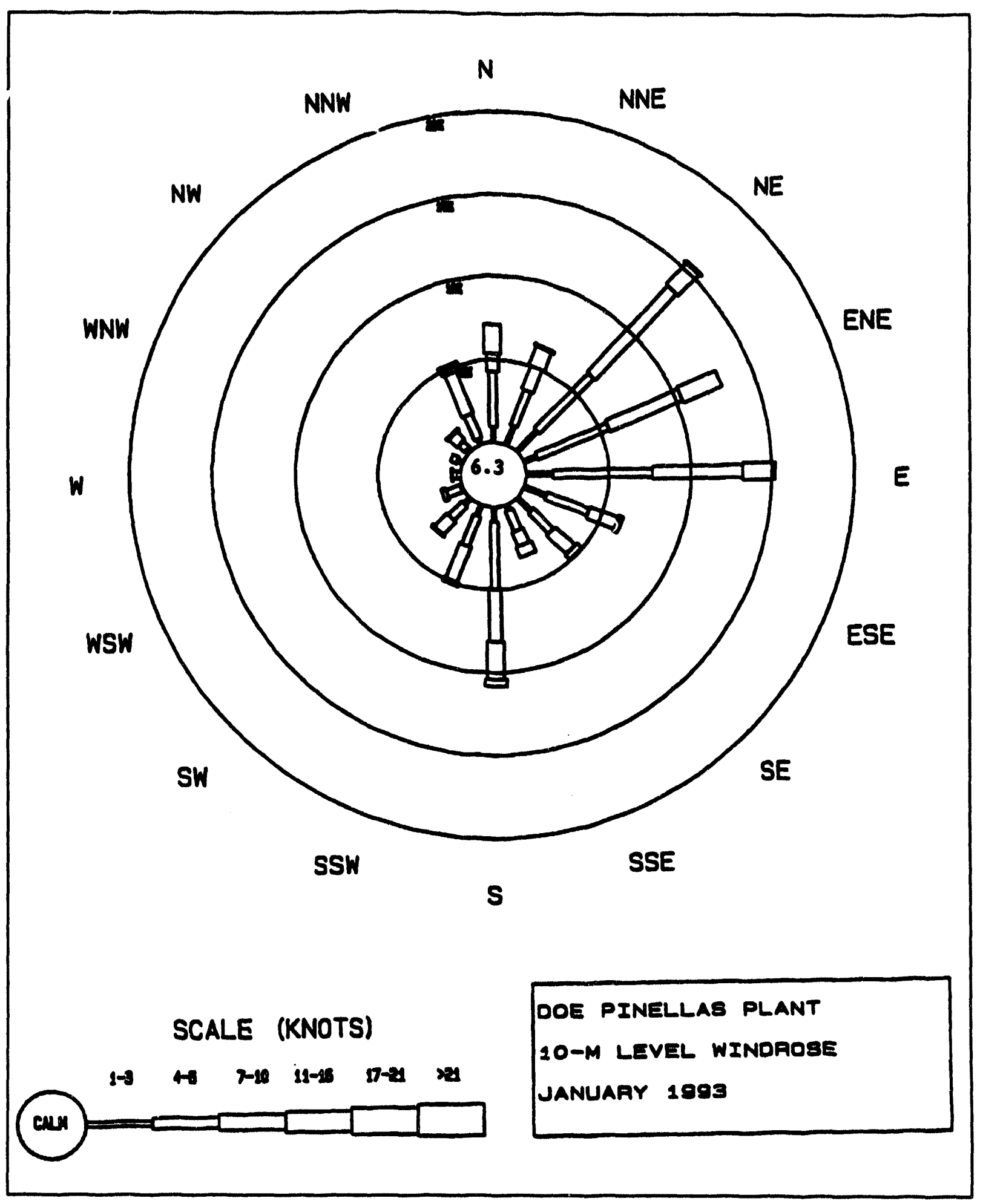

Figure 1-3. January 1993 Pinellas Plant Wind Rose 


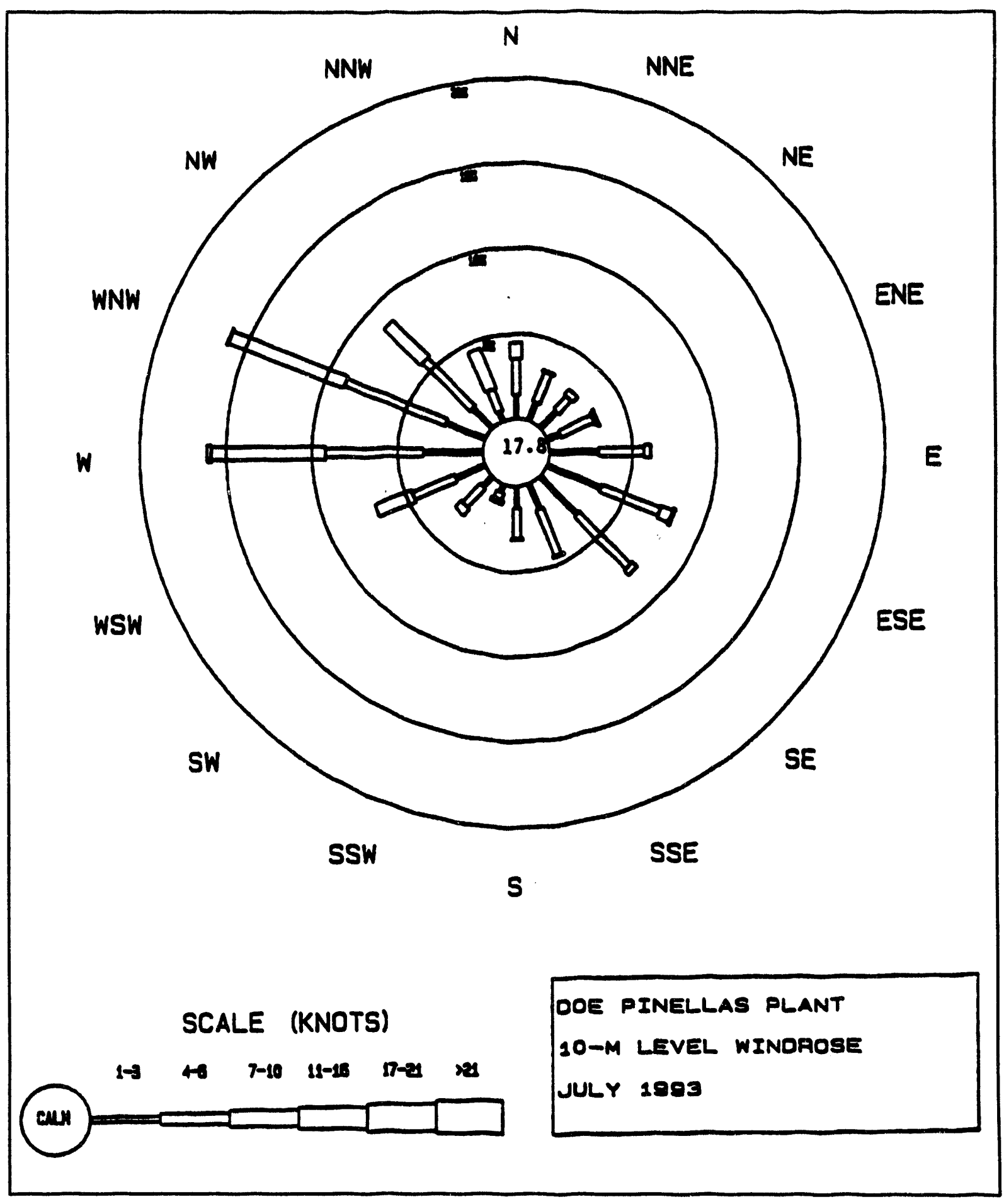

Figure 1-4. July 1993 Pinellas Plant Wind Rose 


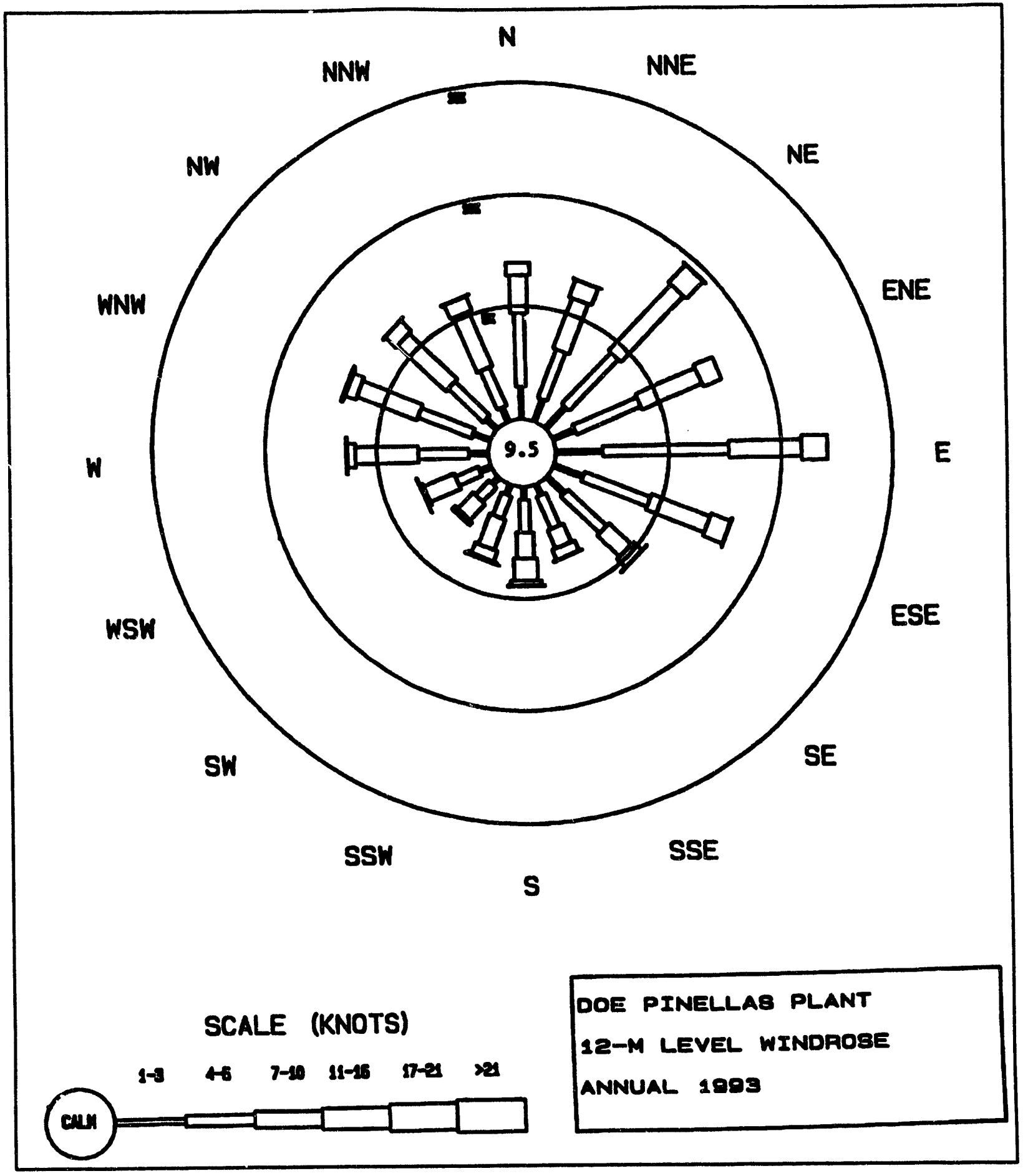

Figure 1-5. Pinellas Plant 1993 Annual Wind Rose 
A relative frequency distribution table for the various wind speed classifications and stability class arrays measured at the Pinellas Plant Meteorological Station during 1993 is shown in Table 1-1. The data presented is a good characterization of the plant's annual wind regime. Wind speeds are reported in knots. The stability classifications were determined from the Pasquill-Gifford scheme, which uses temperature differential gradients and solar radiation intensities to determine atmospheric stability. Table 1-2 is a summary of some of the parameters monitored at the plant. This meteorological data is used in combination with other environmental data in computer models to characterize the local impacts of the plant's activities. Some computer model applications such as radiological dose modeling are discussed in Section 4. 
Table 1-1. Pinellas Plant Meteorological Station Wind Frequency Distribution, 1993, by Wind Speed, Stability Class, and Origin

\section{MNO FREQUENCY DISTAIBUTION AT THE 12.5 METER TOWER PINELLAS PLANT. CALENDAR YEAR 1903}

\begin{tabular}{|c|c|c|c|c|c|c|c|}
\hline & $\begin{array}{l}\text { graverm } \\
\text { auss }\end{array}$ & 12 & 4 & 7.10 & $11 \cdot 10$ & 17.81 & $>21$ \\
\hline N & $A$ & 0.0007 & 0.00100 & 0,00000 & 0.00000 & 0.00000 & 0.00000 \\
\hline WWI & $\bar{A}$ & 0.0000 & Q.000. & 0.00000 & 0.00000 & 0.00000 & 0.00000 \\
\hline$\overline{N E}$ & $\bar{A}$ & 0.00067 & 0.00140 & 0.00000 & 0.00000 & 0.00000 & 0.00000 \\
\hline GNE & $\bar{A}$ & 0.0000 & 0.00114 & 0.00000 & 0.00000 & 0.00000 & 0.00000 \\
\hline E & $A$ & 0.0000 & 0.000 & 0.000000 & 0.00000 & 0.00000 & 0.00000 \\
\hline EE & $A$ & 0.00003 & 0.0010 & 0.000000 & 0.000000 & 0.00000 & 0.00000 \\
\hline$E$ & $\bar{A}$ & 0.00063 & 0.00003 & 0.00000 & 0.00000 & 0.00000 & 0.00000 \\
\hline 85 & $A$ & 0.00003 & 0.0000 & 0.00000 & 0.00000 & 0.00000 & 0.00000 \\
\hline 8 & $A$ & 0.000034 & 0.0010 & 0.00000 & 0.00000 & 0.00000 & 0.000000 \\
\hline Dw & $A$ & 0.00003 & 0.00016 & 0.00000 & 0.00000 & 0.00000 & 0.00000 \\
\hline sw & $A$ & 000003 & 0.00067 & 0.00000 & 0.00000 & 0.00000 & 0.00000 \\
\hline Wow & $\bar{A}$ & 0.0000 & 0.0000 & 0.00000 & 0.000000 & 0.00000 & 0.000000 \\
\hline$w$ & $A$ & 0.0000 & 0.00067 & 0.00000 & 0.00000 & 0.00000 & 0.00000 \\
\hline$\overline{W w}$ & $A$ & 0.00003 & 0.00011 & 0.00000 & 0.00000 & 0.00000 & 0.00000 \\
\hline $\mathrm{NW}$ & $A$ & 0.00011 & 0.0007 & 0.00000 & 0,00000 & 0.00000 & 0.00000 \\
\hline Now & $A$ & 0.00010 & 0.0003 & 0.00000 & 0.000000 & 0.00000 & 0.00000 \\
\hline$N$ & 8 & 0.00004 & 0.00000 & 0.00000 & 0.00000 & 0.00000 & 0.00000 \\
\hline$\overline{\mathrm{NW}}$ & $\bar{B}$ & 0.00003 & 0.00000 & 0,00000 & 0.000000 & 0.00000 & 0.000000 \\
\hline $\bar{N}$ & B & 0.00011 & 0.00100 & 0.000000 & 0.00000 & 0.00000 & 0.000000 \\
\hline ENe & $\bar{B}$ & 0.00000 & 0.0010 & 0.00011 & 0.000000 & 0.00000 & 0.000000 \\
\hline$E$ & $\bar{B}$ & 0.00000 & 0.0017 & 0.00011 & 0.000000 & 0.00000 & 0.00000 \\
\hline EES & D & 0.00011 & 0,0000 & 0.00000 & 0.00000 & 0.00000 & 0.000000 \\
\hline E & 0 & 0.00000 & 0.00000 & 0.00000 & 0.000000 & 0.00000 & 0.00000 \\
\hline ges: & D & 0.00000 & 0.00007 & 0.00000 & 0.00000 & 0.00000 & 0.00000 \\
\hline 8 & 8 & $0.000 x$ & 0.0000 & 0.00000 & 0.00000 & 0.00000 & 0.00000 \\
\hline $80 w$ & $\bar{B}$ & 0.000000 & 0.00157 & 0.0000 & 0.000000 & 0.00000 & 0.00000 \\
\hline$\overline{w w}$ & 8 & 0.00011 & 0.00000 & 0.00000 & 0.00000 & 0.00000 & 0.00000 \\
\hline WEW & 8 & 0.000011 & 0.00003 & 0.00000 & 0.00000 & 0.00000 & 0.00000 \\
\hline$w$ & 8 & 0.000000 & 0.0000 & 0.00000 & 0.00000 & 0.00000 & 0.000000 \\
\hline$\overline{\text { WWW }}$ & 3 & 0.00011 & 0.0002 & 0.00000 & 0.00000 & 0.00000 & 0,00000 \\
\hline$M w$ & 8 & 0.00011 & 0.0010 & 0.00000 & 0.00000 & 0.00000 & 0.00000 \\
\hline Nhw & 8 & 00000 & 0.00002 & 0.00000 & 0.00000 & 0.00000 & 0.00000 \\
\hline$N$ & C & 0.00004 & 0.0000 & 0.00000 & 0.00000 & 0.00000 & 0.00000 \\
\hline $\mathrm{NN}$ & c & 0.00011 & 0.00100 & 0.00002 & 0.00000 & 0.00000 & 0.00000 \\
\hline$N$ & C & 0.00003 & 0,0000 & 0.00062 & 0.00000 & 0.00000 & 0.00000 \\
\hline Ex: & c & 0.00000 & $0.002 \pi$ & 0.00172 & 0.00000 & 0.00000 & 0.00000 \\
\hline$E$ & $\bar{c}$ & 0.00000 & 0.0040 & 0.00020 & 0.00000 & 0.00000 & 0.00000 \\
\hline$E S E$ & C & 0.00040 & 0.0000 & 0.00103 & 0.00000 & 0.000000 & 0.00000 \\
\hline 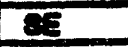 & c & 0.00000 & 0.00114 & 0.00000 & 0.00000 & 0.00000 & 0.00000 \\
\hline 88 & c & 0.00000 & 0.00000 & 0.00003 & 0.00000 & 0.00000 & 0,000000 \\
\hline 8 & C & 0.00007 & 0.00140 & 0.00100 & 0.00000 & 0.000000 & 0.00000 \\
\hline ESW & C & 0.0000 & 0.0010 & 0.0002 & 0.00011 & 0,00000 & 0.00000 \\
\hline $8 w$ & C & 0.00000 & 0.00172 & 0.00017 & 0.00000 & 0.00000 & 0.00000 \\
\hline$\overline{W \sigma W}$ & C & 0.0000 & 0.00000 & 0.00114 & 0.00000 & 0.00000 & 0.00000 \\
\hline$w$ & c & 0.00000 & 0.0017 & 0.00140 & 0.00000 & 0.000000 & 0.00000 \\
\hline Ww & C & 0.00003 & 0.00000 & 0.00000 & 0.00000 & 0.00000 & 0.00000 \\
\hline$N W$ & C & 0.00000 & 0.00112 & 0.01201 & 0.0000 & 0.00000 & 0.00000 \\
\hline NWW & $\bar{c}$ & 0.000 & $0002 \pi$ & 0.00006 & 0.00114 & 0.00000 & 0.00000 \\
\hline
\end{tabular}


Table 1-1 (Continued). Pinellas Plant Meteorological Station Wind Frequency Distribution, 1993, by Wind Speed, Stability Class, and Origin

\begin{tabular}{|c|c|c|c|c|c|c|c|}
\hline & anes & 13 & 4 & $7 \cdot 10$ & $11-10$ & 1791 & $>21$ \\
\hline$N$ & D & 0.0010 & Demont & conore & acosen & 0.00000 & 0.00000 \\
\hline $\mathrm{Nm}$ & 0 & acores & $000 ?$ & o010 & 00004 & 0.00011 & 0.0000 \\
\hline$N / 3$ & 0 & 0.000 & encer & acons & cores & 0.0000 & 0.0000 \\
\hline $\mathrm{ENE}$ & D & 0.00140 & onces & acon & ocoes & 0.0000 & acoen \\
\hline E & D & 0.0019 & acies & acont & aortes & 0.0000 & 00000 \\
\hline ES & D & 00000 & acous & aco10 & 00012 & o.cores & 0.00000 \\
\hline 8 & 0 & 0.0003 & acies & oover & cocests & 0.00000 & 0.00011 \\
\hline 83 & D & 0.0017 & Dollo: & $000 x$ & 0.000 & 0.00011 & 0.00000 \\
\hline & 0 & 000140 & aceor & eotor & aceins & 0.0000 & 00001 \\
\hline $\sin$ & 0 & 0.00100 & acoses & ootich & o.cones & 0.00103 & acopt \\
\hline W & D & 0.0007 & ocones & acores & ocores & 0.00000 & 0.00000 \\
\hline Wu & D & 0.000 & 0002 & aoters & 0.00140 & 0.00000 & 0.00011 \\
\hline$w$ & $\bar{D}$ & 0.00180 & 00090 & opares & 0.0052 & 0.00000 & 0.000 \\
\hline WwN & D & 0.000 & aon212 & acran & 0.0015 & 0.0001 & acoise \\
\hline$N w$ & 0 & 0.00114 & ansts & 0.0101 & 0.0048 & 0.00011 & 0.00000 \\
\hline anw & 0 & 0000 & ooren & 0.01Ca & 0.0057 & 0.0003 & 0.0000 \\
\hline$N$ & $B$ & acoras & Doraler & 0.00010 & 0.00000 & 0.00000 & ac000 \\
\hline $\mathrm{NWS}$ & $E$ & aco12 & 00006 & 0.00t4e & 0.00000 & 0.00000 & 0.00000 \\
\hline NE & E & acoes & 0.01037 & 0.0001 & 0.00000 & 0.00000 & 0.00000 \\
\hline$E^{3}$ & $E$ & acore & aories & aceen & 0.00000 & 0.00000 & 0.00000 \\
\hline$E$ & E & acosis & acons & a.0018s & 0.00000 & 000000 & 0.00000 \\
\hline EE & $E$ & acose & corri & 000312 & 0.00000 & 0.00000 & 0.00000 \\
\hline 83 & $\mathrm{E}$ & a.coses & 00110 & acorre & 0.00000 & 0.00000 & 0.00000 \\
\hline 80 & $E$ & 0.00184 & acoras & 000011 & 0.00000 & 0.00000 & 0.00000 \\
\hline 8 & $E$ & 0.00040 & 0.0000 & 0.00011 & 0.00000 & 0.00000 & 0.00000 \\
\hline $85 \%$ & $E$ & acois & e.0010 & 0.01000 & 0.00000 & 0.00000 & 0.00000 \\
\hline $8 x$ & $E$ & ocotes & acoere & 0.00011 & 0.00000 & 0.00000 & 0.00000 \\
\hline Waw & $E$ & 0.0007 & 0.00628 & 0.0002 & 0.00000 & 0.00000 & 0.00000 \\
\hline$W$ & $E$ & acoos & .000034 & 0.0020 & 0.00000 & 0.00000 & 0.00000 \\
\hline wnw & $E$ & ocopes & 0.0001 & 0.00011 & 0.0000 & 0.0000 & 0.00000 \\
\hline$N W$ & $E$ & 000140 & 0.00340 & 0.0000 & 0.00000 & 0.00000 & 0.00000 \\
\hline NWW & $E$ & 0.0019 & 0.000 & 0.00000 & 0.00000 & 0.00000 & 0.00000 \\
\hline $\mathbf{N}$ & $F$ & 0.0000 & copess & 0.00000 & 0.00000 & 0.00000 & 0.00000 \\
\hline NNE & $F$ & 0.0002 & $0.001 c 3$ & 0.00000 & 0.00000 & 0.00000 & 0.00000 \\
\hline NE & $F$ & 0.000 & acois & 0.00000 & 0.00000 & 0.00000 & 0.00000 \\
\hline ENE & $F$ & 0.0000 & 0.0050 & 0.00000 & 0.00000 & 0.00000 & 0.00000 \\
\hline$E$ & $F$ & a.corre & 0.00217 & 0.0000 & 0.00000 & 0.00000 & 0.00000 \\
\hline ESE & $F$ & 0.00080 & 0.0004 & 0.00000 & 0.00000 & 0.00000 & 0.00000 \\
\hline 83 & $F$ & acoes & 0.00011 & 0.00000 & 0.00000 & 0.00000 & 0.00000 \\
\hline $8 s$ & $F$ & 0.00140 & 0.00000 & 0.00000 & 0.00000 & 0.00000 & 0.00000 \\
\hline 8 & $F$ & 0.0000 & 0.00011 & 0.00000 & 0.00000 & 0.00000 & 0.00000 \\
\hline Esw & $F$ & 0.0019 & 0.00011 & 0.00000 & 0.00000 & 0.00000 & 0.00000 \\
\hline $8 w$ & $F$ & 0.0000 & 0.00011 & 000000 & 0.00000 & 0.00000 & 0.00000 \\
\hline Wow & $F$ & 0.0000 & 0.00105 & 0.00000 & 0.00000 & 0.00000 & 0.00000 \\
\hline$w$ & $F$ & 0.0001 & 0.0004 & 0.00000 & 0.00000 & 0.00000 & 0,00000 \\
\hline WwW & $F$ & ocones & acones & 0.00000 & 0.00000 & 0.00000 & 0.00000 \\
\hline $\mathbf{N W}$ & $F$ & 0.0028 & $0.000 x$ & 0.00000 & 0.00000 & 0.00000 & 0.00000 \\
\hline NNW & $F$ & 0.00097 & acopos & 0.00000 & 0.00000 & 0.00000 & 0.00000 \\
\hline TOTA & & 0.1901 & osnas & 0.26313 & 0.103 & 0.0048 & 0.00000 \\
\hline
\end{tabular}


Table 1-2. 1993 Monthly Statistical Summaries for Pinellas Plant Meteorological Monitoring Station

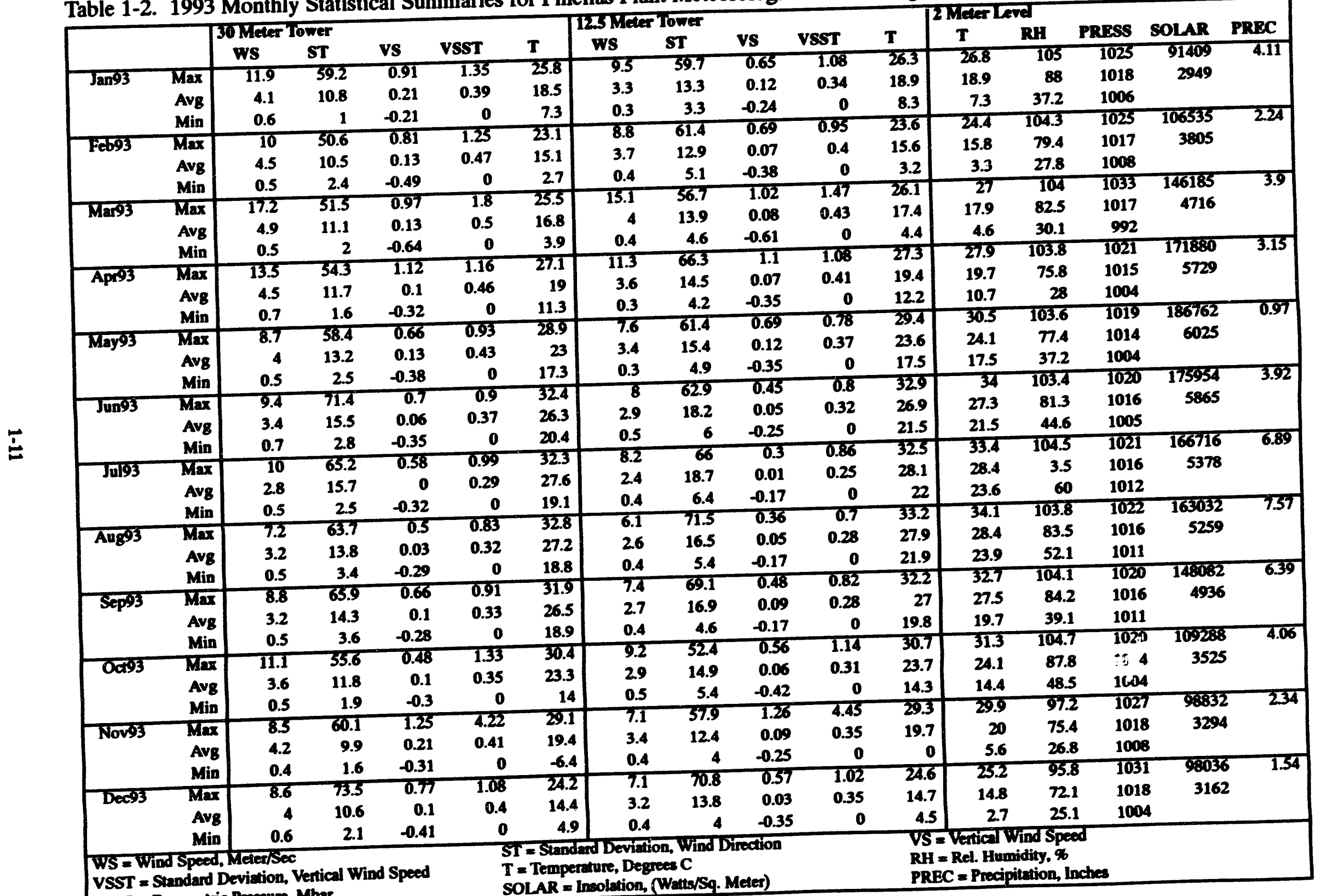

VSST $=$ Standard Deviation, Vertical
PRES = Barometric Presure, Mbar

T= Temperature, Degrees C

PREC = Precipitation, Inche 
The potential for hurricanes exists in the Tampa Bay area. Based on records from 1866 through 1981, the relative frequency of a hurricane passing within an 80 -kilometer (50-mile) radius of the plant site is one in every 8.6 years.

Hurricanes and tropical storms contribute 25 to 30 percent of the area's annual rainfall. The peak hurricane frequency occurs in September and October, with 3.4 storms per decade. The hurricane frequencies for June, July, and August are 0.4, 0.7, and 2.1 per decade, respectively. In general, tropical storm and hurricane frequency are the same. Hurricanes have winds over 74 miles per hour (mph), while tropical storms have peak winds from 39 to $73 \mathrm{mph}$. The hurricane frequency drops from 3.4 storms per decade in October to 0.3 storms per decade in November.

Tidal flooding from hurricanes causes the greatest amount of damage. The Army Corps of Engineers determined the maximum anticipated high tide at approximately 4.3 meters (14 feet) above mean sea level (MSL) based on a design hurricane. Since the plant is several miles inland and has a minimum floor height of 5.6 meters (18.5 feet) above sea level, no damage is expected from tidal flooding. Flood plann maps depicting flooding expected from a "100-year storm" show that the plant is not in a flood-prone zone.

The probability of a tornado striking any point in the Pinellas Plant site is 4.3E-04 per year [Ref. 5]. On October 3, 1992, a series of tornados swept through Pinellas County causing damage and fatalities. The nearest tornado struck about two miles east of the plant. Damage was limited to off-site monitoring stations and was repaired quickly. There were no other environmental damages or impacts to the plant. Waterspouts moving ashore typically dissipate within a few blocks after reaching land, and the potential for damage to the plant is small.

\subsection{Seismology}

The earliest recorded and the most severe earthquake occurred on January 12, 1879 near St. Augustine, Florida [Ref. 6]. The tremors lasted 10 minutes and covered an area of 65,000 square kilometers, or 25,000 square miles, from

Savannah, Georgia in the north to Daytona Beach, Florida in the south. The only damage reported was in St. Augustine, where some residents were showered with ceiling plaster. Several events of less intensity have been reported since then. Smaller events probably occurred and escaped detection because of the distance to the nearest seismic station, and the tendency of the residents to identify these with the space shuttle, rockets, or airplanes. There is no reasonable expectancy for damaging earthquakes at the plant. The seismic risk map of the United States shows Central and Southern Florida in Zone 0 (Figure 1-6), a "no damage" zone. 


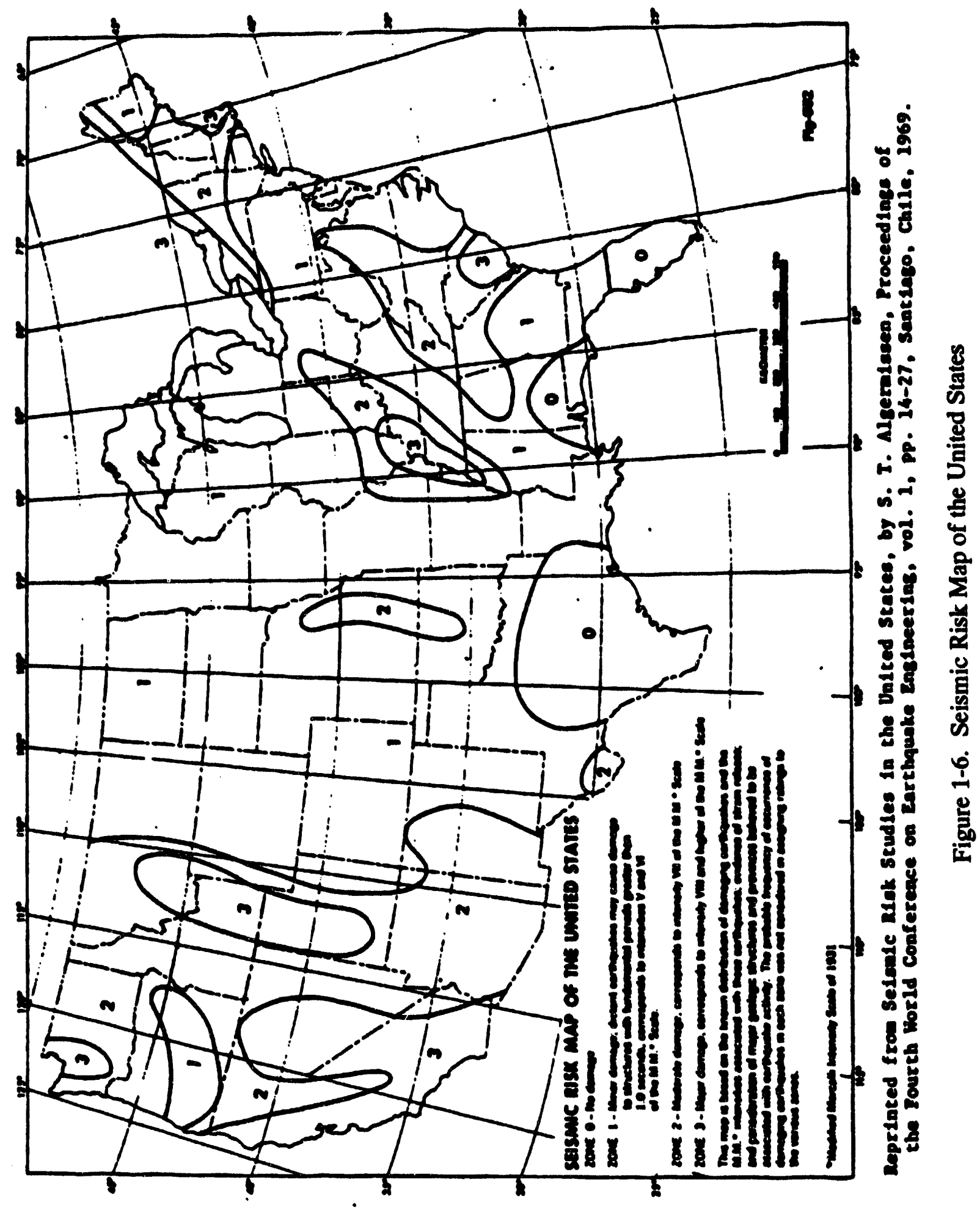




\subsection{Land Use}

The Pinellas Plant site and the adjacent properties to the east and west are zoned for heavy and light industrial use, respectively. Within a 1-kilometer radius to the north, northeast, and southwest are residential areas zoned at a maximum of 10 units per acre. A golf course to the south of the plant site provides a 1-kilometer-wide buffer to the nearest residential area. The East and West Ponds (Figure 1-7) are designated as wetlands by the U.S. Department of the Interior, Fish and Wildlife Service's National Wetlands Inventory [Ref. 7]. No historic or archaeological sites are located on the plant site. 
North Boundary frence)

$\overrightarrow{\dot{a}}$

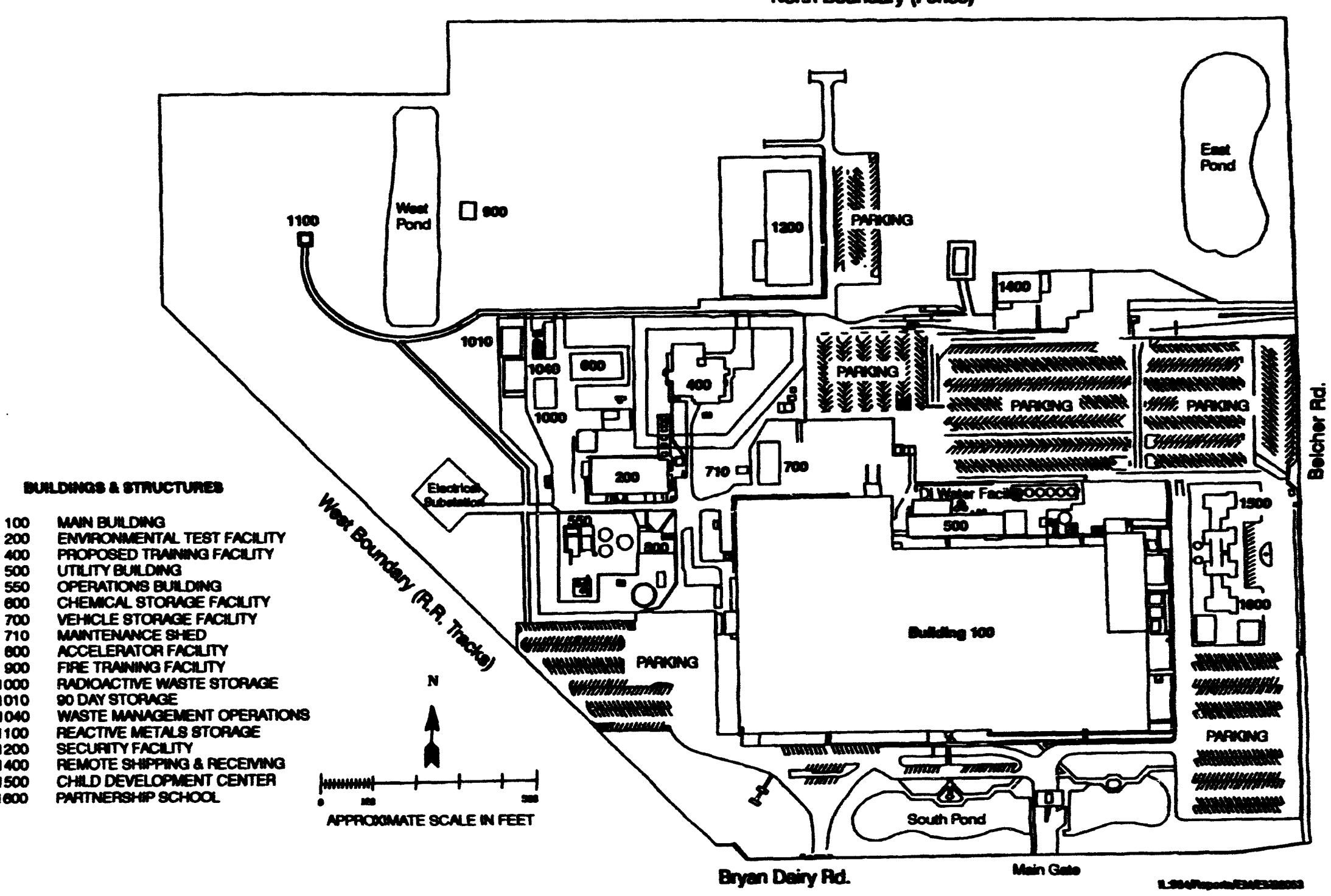

Figure 1-7. Pinellas Plant Site Layout 


\subsection{Population}

Pinellas County remains the most densely populated county in the state, with over 75\% of the total land area dedicated to urbanized use. The estimated 1992 resident population was 908,000 . Of this total, 864,000 are permanent residents, and 44,000 , or $5 \%$, ar 2 considered seasonal residents. The seasonal variations in population generally peak during March, with a corresponding trough occurring in late June. This cyclic pattern has been repeatedly demonstrated through the years. Table 1-3 is a brief table of statistics on Pinellas County's population based on the decennial U. S. census tables for the years the Pinellas Plant has operated. The estimated 1992 population density is 3.6 times greater than it was when the plant started operations in 1957.

Table 1-3. Pinellas County Population Statistics

\begin{tabular}{|c|c|c|}
\hline Year & Population & $\begin{array}{l}\text { Average Population } \\
\text { Denalts, Persona/Acre }\end{array}$ \\
\hline $1950^{1}$ & 159,249 & 0.89 \\
\hline $1956^{*}$ & 250,000 & 1.4 \\
\hline $1960^{1}$ & 374,665 & 2.1 \\
\hline $1970^{1}$ & 522,329 & 2.9 \\
\hline $1980^{1}$ & 728,531 & 4.1 \\
\hline $1990^{1}$ & 851,659 & 4.8 \\
\hline $1992^{2}$ & 908,000 & 5.1 \\
\hline \multicolumn{3}{|c|}{ 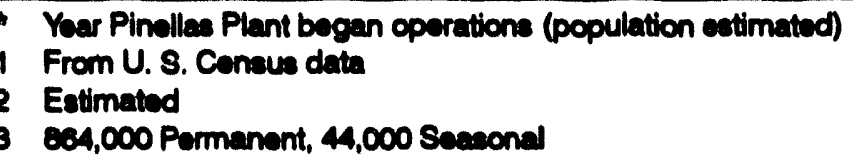 } \\
\hline
\end{tabular}

In 1992, the Pinellas Plant conducted a study to determine the distribution of the population within $\mathbf{5 0}$ miles of the plant site. Based on the study, the greatest population densities are in the northwest and southeast quadrants, and at a distance greater than 10 kilometers. Over 2.5 million people reside within this 50-mile radius. This data was obtained from the $1990 \mathrm{U}$. S. Census and is presented in Table 1-4. 
Table 1-4. 1990 Population by Sector-Segment

\begin{tabular}{|c|c|c|c|c|c|c|c|c|c|}
\hline \multicolumn{10}{|c|}{1990 Populations by Sectorsegment Cumulative Totals } \\
\hline \multirow[b]{2}{*}{ Directos } & \multicolumn{9}{|c|}{ Distance (Millea) } \\
\hline & $0-2$ & $\mathbf{0 - 3}$ & $0-4$ & $0-5$ & 0.10 & $0-20$ & $0-30$ & $0-40$ & 0.50 \\
\hline $\mathbf{N}$ & 2,421 & 8,250 & 13,814 & 20,577 & 77,079 & 184,807 & 295,815 & 342,718 & $\mathbf{3 4 8 . 0 4 2}$ \\
\hline NNE & 3,806 & 8,034 & 12,428 & 16,549 & 41,695 & 76,051 & 91,591 & 115,686 & 184,974 \\
\hline NE & 2,594 & 4,381 & 8,664 & 10,191 & 10,196 & 123,547 & 236,574 & 256,638 & 308,734 \\
\hline ENE & 1,790 & 2,389 & 3,285 & 4,505 & 5,922 & 146,372 & 331,993 & 382,782 & 452,597 \\
\hline$\overline{\mathbf{E}}$ & 2,558 & 3,703 & 4,534 & 5,025 & 17,582 & 70,487 & 153,901 & 189,240 & 239,819 \\
\hline ESE & 1,900 & 7,364 & 14,304 & 18,755 & 67,698 & 70,230 & 103,531 & 106,379 & 106,919 \\
\hline SE & 1,818 & 5,341 & 11,052 & 16,633 & 87,174 & 106,883 & 120,460 & 123,815 & 126,122 \\
\hline$\overline{\text { SSE }}$ & 1,597 & 6,054 & 12,646 & 21,593 & 86,904 & 119,934 & 219,238 & 357,192 & 482,892 \\
\hline $\mathbf{S}$ & 2,324 & 3,842 & 9,670 & 15,549 & 46,337 & 53,809 & 66,439 & 69,142 & 69,142 \\
\hline SSW & 4,317 & 7,487 & 9,964 & 14,678 & 21,208 & 21,208 & 21,208 & 21,208 & 21,208 \\
\hline SW & 2,288 & 3,879 & 9,630 & 14,867 & 19,559 & 19,559 & 19,559 & 19,559 & 19,559 \\
\hline WSW & 1,575 & 4,992 & 11,655 & 18,316 & 24,490 & 24,490 & 24,490 & 24,490 & 24,490 \\
\hline $\bar{W}$ & 2,371 & 7,525 & 10,562 & 17,551 & 26,603 & 26,603 & 26,603 & 26,603 & 26,603 \\
\hline WNW & 2,140 & 7,137 & 12,514 & 21,260 & 28,300 & 28,300 & 28,300 & 28,300 & 28,300 \\
\hline NW & 1,553 & 5,068 & 10,760 & 19,026 & 27,477 & 27,477 & 27,477 & 27,477 & 27,477 \\
\hline NNW & 1,013 & 4,459 & 10,404 & 18,298 & 60,032 & 62,991 & 62,991 & 62,991 & 62,991 \\
\hline
\end{tabular}

\subsection{Water}

Pinellas County is one of 16 Florida counties in the Southwest Florida Water Management District. Over $95 \%$ of the water used in this district was withdrawn from groundwater in the Floridan Aquifer. Water use in Pinellas County in 1993 averaged 53.98 million gallons per day. During 1993, the Pinellas Plant discharged approximately 78 million gallons of water to the Pinellas County Sewer System (PCSS). 
This page left blank intentionally. 


\subsection{COMPLIANCE SUMMARY}

\subsection{Complinnce Status}

In 1993, the Pinellas Plant operated within the allowable discharge limits for both radioactive and nonradioactive materials to the ambient air and water. In the Hazardous Waste Management Program, the Florida Department of Environmental Protection (FDEP) inspectors found three "minor violations," two in a satellite accumulation area and one for an improper label. All deficiencies were corrected immediately. Also in the Hazardous Waste Management Program, the FDEP conducted an unannounced inspection in November 1993, and cited the plant for two "potential violations," one for storage of liquid waste and the other for lack of preparation of a contingent post-closure plan for bulk waste storage. All issues were resolved. The remaining sections of this Compliance Summary include compliance activities under specific regulations.

\subsubsection{Clean Alr Act}

\section{Radiological Emissions}

The 1993 Radionuclide Air Emissions Annual Report is submitted to the EPA in June 1994. The report concluded that the effective dose equivalent to the most exposed member of the public was 2.3E-3 mrem/yr. This is well below the $10 \mathrm{mrem} / \mathrm{yr}$, EPA standard [Ref. 8]. However, there is no full-time resident at this location. The highest estimated dose to an actual resident was less than the dose to the theoretical most exposed individual and was calculated to be $1.9 \mathrm{E}-03(0.0019)$ mrem. This was at a location 620 meters west southwest of the main radiological exhaust stack. CAP88-PC, an EPA approved computer code, was used to estimate the effective dose equivalent.

The Pinellas Plant annually tests stack flowrates to verify the continuous monitoring data for flowrate. The flowrate of all four radiological exhaust stacks were measured in December 1993, and verified to be comparable to December 1991 and October 1992 measurements.

The 1993 Annual Radionuclide Emissions Minor Source Compliance modeling run was conducted in April 1993. It utilized the EPA-approved COMPLY computer model using a worst-case emission scenario of 1700 curies of tritium and 100 curies of krypton-85 released from the main radiological exhaust stack. This worst-case scenario assumed the Tritium Recovery System, an emission control device, was not operational resulting in the uncontrolled release of all the tritium processed in 1993. The Tritium Recovery System normally removes $\mathbf{9 9 . 9 \%}$ of all tritium prior to discharge through the Building 100 main stack. The report documented that even under this "worst-case" simulation, the dose would 
be $9.6 \mathrm{E}-02(0.096) \mathrm{mrem} / \mathrm{yr}$ which is below the $0.1 \mathrm{mrem} / \mathrm{yr}$ standard [Ref. 9] for the effective dose equivalent to the most exposed individual. This confirms EPA's designation of the plant as a minor source for radionuclide emissions. The Pinellas Plant is therefore not required to continuously monitor the radiological exhaust stacks. As a best management practice and to provide assurances to the community, however, continuous monitoring and sampling are performed on all four radiological exhaust stacks and around the perimeter of the plant and at locations in Pinellas and Manatee Counties.

\section{Nonradiological Air Emissions Permitting}

The 1992 Annual Site Environmental Report [Ref. 9] detailed the background of the Plant's initiatives to comply with the requirements of the Clean Air Act (CAA). As reported, this effort resulted in the January 7, 1993 receipt of an air pollution source construction permit, AC52-206678 [Ref. 10], covering plantwide nonradiological emissions. The Florida Department of Environmental Regulation, now the FDEP, issued the permit which expires on December 31, 1994.

The Pinellas Plant provided routine updates through correspondence to the Pinellas County Air Quality Division (PCAQD) and the FDEP to reflect changes in plant operations pursuant to air permitting requirements. The Pinellas Plant also held negotiations with the PCAQD and the FDEP on the current Pinellas Plant defense mission, the plant consolidation initiative and the commercialization of plant operations.

The Pinellas Plant conducts emissions testing in association with maintaining permit conditions. To comply with the permitting requirements, the Pinellas Plant developed an Operations and Maintenance Plan which detailed the activities associated with operating and maintaining the pollution control equipment.

The Pinellas Plant uses a chemical budgeting and log keeping system to track selected chemicals (1000 lbs or more used per year) on the production floor. All production personnel have subsequently been trained in log keeping requirements.

Implementation of log keeping and chemical usage budget requirements assures that the Pinellas Plant remains in compliance with permitted air emissions constraints. Certification of Completion of Construction package was submitted to the FDEP and PCAQD in June 1993. Pending regulatory review and acceptance of the package, issuance of a 5-year Operating Permit is anticipated in 1994. 
The Pinellas Plant routinely obtains and reviews proposed and final regulations from the Federal Register. Reviews are formalized and impacts are disseminated to affected Pinellas Plant departments and operations.

The Pinellas Plant identified three titles of the CAA Amendments of 1990 which will significantly impact operations at the plant. These are Titles III, V, and VI. The Pinellas Plant will implement changes to its operations and/or permits as required by forthcoming regulations upon promulgated.

\section{Title III - Hazardous Air Pollc ants (HAPs)}

This title of the CAA Amendments incorporates emissions standards and guidelines which will regulate the emissions of EPA's list of 189 HAPs. EPA will be promulgating a series of proposed rules which are anticipated to have impacts on future plant operations. There impacts will include: stricter operations control on degreasing operations, enhanced record keeping requirements, and the replacement of volatile solvents with non-volatile substiwutes.

\section{Title V - State and Federal Applicability}

This title of the CAA Amendments incorporates Federal policy and requirements which will streamline permitting requirements for air pollution sources. The Pinellas Plant is evaluating its air emissions to determine the applicability of Title V. Although the Title V Program will not mandate any specific emissions limiting standards on its own, the plant may be required to modify its existing air permit in accordance with Title $\mathbf{V}$ requirements. This modification would result in the requirement for a new emissions permit which is consistent with EPA's Federal Title V permitting strategy. The Pinellas Plant will determine in 1994 the applicability of Title $\mathrm{V}$.

\section{Title VI-Stratospheric Orone Protection}

This title of the CAA Amendments incorporates a comprehensive body of regulations designed to regulate and systematically phase out the use of chlorofluorocarbons as part of EPA's effort to address the issue of stratospheric ozone depletion. Examples at there impacts include the replacement of comfort cooling CFC refrigerants with non-CFC replacements and the substitutions of Freon cleaning solvents with aqueous cleaning agents. The Pinellas Plant is identifying the impacts of the numerous proposed rules under Title VI. 


\subsubsection{Clean Water Act (CWA)}

The Pinellas Plant discharges industrial wastewater and untreated sanitary sewage to the Pinellas County Sewer System Publicly Owned Treatment Works (POTW) in accordance with the plant's Industrial Wastewater Discharge Permit, 018-IE. Discharges during 1993 did not violate the permit limits, Federal Metal Finishing Pretreatment Standards, or Pinellas County Ordinance 91-26 [Ref. 11,12,13].

\section{National Pollutant Discharge Dllmination System (NPDES)}

The Pinellas Plant does not currently have an NPDES permit for stormwater discharge associated with industrial activities. The Pinellas Plant sampled two stormwater outfalls and submitted a permit application to the EPA in September 1992. In 1993, an additional stormwater outfall was discovered and the discharge was subsequently sampled during two representative storm events. The Pinellas Plant prepared a revised stormwater discharge permit application for submittal to the EPA.

\subsubsection{Safe Drinling Water Act (SDWA)}

The Pinellas Plant is in compliance with drinking water quality standards. Potable water is purchased from the Pinellas County Water System (PCWS). The plant does not perform any potable water treatment activities.

\subsubsection{Resource Conservation and Recovery Act (RCRA)}

The Pinellas Plant's Hazardous Waste operations are committed to achieving compliance with the Code of Federal Regulations (CFR) 40, Parts 260-264, 266, 268, and 270, Chapter 17-730 of the Florida Administration Code (FAC), and the plant's Hazardous Waste Facility Permit, HO52-159339, issued by the FDEP on January 22, 1990.

The Pinellas Plant's Waste Management (WM) Program submitted a Hazardous Waste Facility Permit renewal application to the FDEP in April 1993. Comments were received from the FDEP in a "Notice of Deficiency" (NOD), dated July 14,1993 . The plant responded to all comments on October 12, 1993, except those pertaining to treatment operations. The treatment operations comments were deferred until April 1994. Upon review of the plant's NOD response, the FDEP sought clarification on four minor items and approved the remainder of the submittal on November 19, 1993.

The Pinellas Plant stores and/or treats hazardous wastes, but no hazardous wastes are disposed of on the plant site (i.e., landfills, lagoons, etc.).

During 1993, 319 drums of RCRA hazardous and nonhazardous wastes 
were shipped from the Pinellas Plant for disposal. All hazardous waste is shipped off the plant site for disposal at an RCRA-approved disposal site. Hazardous waste storage at the Pinellas Plant falls under two categories, 90-day storage for "unpermitted" hazardous waste, or permitted storage not to exceed one year. Permitted storage for hazardous waste is identified in the Hazardous Waste Facility Permit. Treatment operations include thermal treatment of small charge explosives and chemical treatment of water reactive compounds, such as calcium metal, calcium bimetals, and solid wastes contaminated with lithium metal. The Pinellas Plant conducts all treatment operations in accordance with methodologies detailed or referenced in the plant's Hazardous Waste Facility Permit.

The FDEP and/or the EPA inspect the plant's hazardous waste operations at least annually to assure compliance with governing regulations. On April 30, 1993, FDEP inspected the plant. The FDEP inspectors found three minor violations, two for open containers in a satellite accumulation area, and one for an improper label. All deficiencies were corrected immediately. The plant also had an "unannounced" FDEP inspection on November 9, 1993. The plant was cited for two "potential violations," one citation was for storage of liquid waste in one of the plant's hazardous waste storage bays and the other for not preparing and submitting a contingent post-closure plan for bulk waste storage (i.e., hazardous waste tank storage). All issues are actively being addressed.

There are no Underground Storage Tanks (UST) at the Pinellas Plant. The last UST was removed from the plant in September 1991 in accordance with Pinellas County Public Health Unit regulations.

\section{Hazardous and Solid Waste Amendments (HSWA)}

The plant's HSWA Permit issued by EPA Region IV requires the permittee to investigate any releases or potential releases of hazardous waste or hazardous constituents from any Solid Waste Management Units (SWMUs) at the plant regardless of the time the waste was placed in the unit. It also requires appropriate corrective actions for any releases.

The Pinellas Plant completed an investigation of 15 SWMUs in accordance with the HSWA portion of the plant's RCRA Part B Permit, issued February 9, 1990. The Plant received final approval of the RCRA Facility Investigation (RFI) Report from the EPA in February 1993. This report recommended corrective measures for only four SWMUs. Corrective Measure Studies (CMSs) were completed for three of these SWMUs. During January and February 1993, the Pinellas Plant conducted an Interim Corrective Measure at the Former Pistol Range SWMU. As part of this action, the plant submitted a final interim report to EPA in April 1993. This interim measure also served as the final corrective measure. 
In 1992, a new SWMU was discovered, the West Fenceline area. This site was assessed in 1993 and the RCRA Facility Assessment (RFA) and the RFI requirements were satisfied. An Interim Measures Plan was submitted for the West Fenceline Area. This Interim Measure proposed a technology for cleanup that is both innovative and is expected to have application at other Pinellas Plant SWMUs.

The Pinellas Plant conducted a RFA in 1993 at the Building 200 Area and the Wastewater Neutralization Area. The RFA report included a recommendation to the EPA that they be added as SWMUs to the facility's HSWA permit and an RFI be performed.

\subsubsection{Comprehensive Environmental Response, Compensation, and Llability Act (CERCLA)}

Under CERCLA Section 120, each department, agency, and instrumentality of the United States is subject to, and must comply with, CERCLA as any nongovernmental entity. This includes reporting spills and environmental releases to the EPA that exceed the regulatory quantity threshold. There were no reportable quantity $(R Q)$ releases at the Pinellas Plant during 1993. An RQ release has never occurred at the plant.

The plant is currently involved in the assessment of one CERCLA site, Peak Oil. Peak Oil was a used oil reclamation facility and has been placed on the National Priorities List by EPA. EPA identified the Pinellas Plant as one of many Potentially Responsible Parties (PRPs). The plant participates in cleanup through the PRP steering committee.

\subsubsection{National Environmental Policy Act (NEPA)}

The National Environmental Policy Act of 1969, as amended, requires "all agencies of the Federal Government" to prepare a detailed statement on the environmental effects of proposed "major Federal actions significantly affecting the quality of the human environment." The Pinellas Plant administers an in-house NEPA program to assess planned changes in plant facilities and operations. Table 3-5 of the 1993 Site Environmental Report identifies NEPA activities that occurred in 1993.

Significant 1993 NEPA activities included two Environmental Assessments (EA), the Pinellas Plant Consolidation Initiative, and the Commercialization of Pinellas Plant Buildings and Facilities Environmental Assessment. The "Consolidation" EA was developed to address NEPA considerations from activities associated with the consolidation of laboratory and manufacturing functions to meet the change in the overall plant mission that resulted from the DOE complex-wide consolidation effort. After extensive review and consideration, this project was granted a Categorical Exclusion (CX) from further NEPA review. 
The "Commercialization" EA describes conditions that would occur as the result of leasing the plant to commercial entities for the purpose of conducting commercial manufacturing and research activities. This EA was submitted to the DOE Albuquerque Operations Office for review.

\subsubsection{Toxic Substances Control Act (TSCA)}

Matrrials regulated under TSCA include Polychlorinated Biphenyls (PCBs) and asbestos. The Pinellas Plant has no known PCBs on site. The last $\mathrm{PCBs}$ and $\mathrm{PCB}$-contaminated equipment were removed from the site in 1988.

The plant complies with all Occupational Safety and Health Administration (OSHA), EPA, State, and local regulations regarding the management and control of asbestos materials within the facility. The Pinellas Plant developed and implemented an Operations and Maintenance (O\&M) Plan that meets the regulatory requirements of EPA's Asbestos Hazard Emergency Response Action (AHERA). All subject asbestos projects are coordinated to ensure proper project notification to the State and local agencies, as required by EPA through 40 CFR Part 51, National Emission Standard for Asbestos, FDEP, and Pinellas County Ordinance.

\subsubsection{Federal Insecticide, Fungiclde and Rodenticide Act (FIFRA)}

The Pinellas Plant uses pesticides in accordance with applicable regulations. If required, "Restricted Use" pesticides are only applied by contractors licensed by the State of Florida.

\subsubsection{Endangered Species Act (ESA)}

In response to a letter written by the United States Department of Interior, dated July 1991, listing potential endangered species, a subcontractor performed a site survey and found no listed endangered species, as defined in the ESA, at or near the plant. There was no action involving the ESA during 1993.

\subsubsection{National Historic Preservation Act (NHPA)}

Pinellas County has sites of historic and archeological significance. None of these sites are on or in close proximity to the plant. In a letter dated September 1991, the Florida Department of State, Division of Historic Resources, agreed that a survey of the site is unnecessary because it is unlikely that plant operations could impact sites listed or proposed for listing in the National Register.

\subsubsection{Executive Order 11988, "Floodplain Management"}

The Pinellas Plant site is not located in the 100-year flood plain of Pinellas County. The plant is not associated with adverse impacts to the floodplain, as defined in the Floodplain Protection Executive Order. 


\subsubsection{Executive Order 11990, "Protection of Wetlands"}

The U. S. Department of the Interior Fish and Wildlife Service identified the East and West Ponds as designated wetlands on the National Wetlands Inventory. The Pinellas Plant will conduct its activities such that ensures that destruction, loss, or degradation of these wetlands is minimized, as required by the Wetlands Protection Executive Order.

\subsubsection{Emergency Planning and Community Ripht to Know Action of 1986 (EPCRA)}

The Pinellas Plant annually reports the toxic chemical inventory quantities and release quantities required by EPCRA. This act, also known as Title III of the Superfund Amendments and Reauthorization Act (SARA) of 1986, requires the disclosure under Section 312 of Toxic Chemical Inventory data by March 1, and Toxic Chemical Release Reporting by July 1 under Section 313, of each year. The plant is in compliance with the reporting requirements of EPCRA. Six of the sixteen materials reported under Section $\mathbf{3 1 2}$ are extremely hazardous substances. They are ammonia, hydrofluoric acid, nitric acid, phosphorus, sulfuric acid, and toluene 2,4 diisocyanate. MSDSs have been submitted to the local Emergency Planning Committee, State Emergency Response Commission, and the local fire department in accordance with Section 311 for all Section 312 reportable materials.

\subsection{Other Major Envimonmental Ussues and Actions}

\section{Waste Management}

The Pinellas Plant anticipates a "Notice of Intent to Issue" the Hazardous Waste Facility Permit from the FDEP during the second quarter of 1994. This renewed permit will contain hazardous waste storage pre visions; however, no treatment operation provisions will be included. In agreement with the FDEP, the facility plans to submit a permit modification request in the second quarter of 1994 to include treatment provisions.

DOE 5820.2 regulates Low Level Wastes (LLW). The Pinellas Plant's LLW consists of small quantities of classified weapons components and compactable solid wastes such as lab coats, finger cots, shoe covers, tools, and construction debris. These wastes are contaminated with tritium. LLW is stored on the plant site prior to shipments for disposal. The Pinellas Plant uses approved 17C 55-gallon drums and B-25-90-4 steel boxes for shipping LLW. These wastes are disposed of at DOE's Savannah River Site. With the advent of the DOE reconfiguration process, the Pinellas Plant will handle and ship an increased amount of radioactive waste over the next two years. 
Current issues affecting the plant are the possibility of generating and disposing of "mixed" (hazardous and radioactive) wastes, as regulations regarding these wastes become more stringent. Two commercial sources that accept LLW containing RCRA-prohibited material, resulting in Low Level Mixed Waste (LLMW), were identified and the process of obtaining disposal privileges (acceptance) was initiated. Also, the Nevada Test Site (NTS) may be able to accept LLMW in the near future. Internal controls and additional training were provided in all Radioactive Materials Management Areas (RMMAs) to prevent creation of LLMW.

The Pinellas Plant is awaiting NTS approval for shipment of solidified LLW oils. To expedite the approval process, a subcontractor was requested to assist in preparing an improved Sampling and Analysis Plan to meet NTS NVO-325, Revision 1 criteria. Also, the "Pinellas Plant Moratorium Document" describes procedures to minimize the quantities and types of chemicals permitted in tritium process areas, thus effectively minimizing the potential for the generation of mixed radioactive hazardous wastes. Frequent audits of tritium process areas help to ensure strict compliance with these procedures. The Pine!las Plant WM Program submitted the moratorium document to DOE Headquarters and partial approval has been obtained. Once full approval is received, the moratorium document will be the Pinellas Plant's formal policy.

\section{Environmental Restoration and Permitting}

On October 7, 1993, the Pinellas County Public Health Unit of Health and Rehabilitative Services (HRS) conducted a hazardous substance and petroleum storage tank inspection. The inspection resulted in several minor deficiencies such as cracks in secondary containment systems and inadequate signs. These are actively being adddressed.

On December 21, 1993, the PCSS performed a site inspection that included the production plating area, the photographic silver recovery units, the Industrial Wastewater Neutralization Facility, and the nonhazardous waste treatment process. No violations or noncompliances were identified during the inspection.

The Pinellas Plant compiled a five volume set of radiological release data from the beginning of operations at the Pinellas Plant in 1957 to present and submitted it to HRS in support of the DOE sponsored HRS Epidemiology Feasibility Study. This information was a comprehensive compilation of air and wastewater radiological emission data spanning the 37 years of plant operations.

DOE/PAO and Specialty Components initiated discussions with the PCSS on wastewater disposal from potential commercial businesses which may utilize the Pinellas Plant facility after completion of defense related production in September 1994. The PCSS concurs with the concept of regulating new business wastewater discharges under the existing permit. The PCSS identified the need to develop a specific protocol for either amending the existing permit or issuing auxiliary 
permits. In the interim, the proposed new businesses must comply with the existing permit requirements and a wastewater discharge information form must be submitted to the PCSS for each new business venture that will be located at the plant.

The Pinellas Plant wrote an accidental discharge protection/slug control plan and submitted it to the PCSS for review as a requirement of the wastewater discharge permit. The plan identifies the methods the plant uses to prevent accidental discharges of concentrated pollutants, or slugs, to the PCSS. These methods include routine preventive maintenance and inspections of storage tanks and process equipment, secondary containment, an on-site Hazardous Material Response Team (HAZMAT), and spill response and cleanup equipment. The plant received PCSS comments on the plan and will revise and publish it.

Accelerated cleanup actions of the solvent-contaminated groundwater at the 4.5 Acre Site and the Northeast Site continued through 1993. The remediation technique employed draws the industrial solvent contaminants back onto the site, and reduces the overall concentration of these contaminants in the groundwater. The discharge from the treatment system is routed to the plant's IWNF where it is neutralized, monitored, and discharged to the PCSS. The 4.5 acre site is a voluntary cleanup action. The Northeast Site cleanup is regulated by the plant HSWA permit. There are no milestones associated with the HSWA permit.

Pursuant to EPA approval, the plant began implementing recovery well reconfiguration at the Northeast Site as part of Interim Corrective Measures. The well reconfiguration will optimize recovery of common industrial solvent contaminants from shallow and deep zones of the Surficial Aquifer.

The DOE Innovative Treatment Remediation Demonstration (ITRD) Program selected the Pinellas Plant Northeast Site for its first field demonstration. The mission of this program is to identify appropriate innovative cleanup technologies and collect cost and performance data on these technologies so they will be more widely accepted within the regulatory and commercial arenas. In 1993, technologies were reviewed and three were chosen for further evaluations for use at the Northeast site: enhanced bioremediation, reductive dehalogenation, and dynamic steam stripping. Further evaluations of these technologies will be performed in 1994 in parametric models, treatability studies, and pilot studies. Based on study results, one or more of these technologies may be selected and implemented at the Northeast site. A detailed report on groundwater monitoring is prevented in Section 6.

\subsubsection{Tiger Team Assessment of the Pinellas Plant, January 1990}

Sixty-one findings were identified during the environmental assessment portion of the Tiger Team Assessment of the Pinellas Plant, January 1990. Of these 61 findings, 14 concerned air emissions, one pertained to soil sampling, 12 were solid waste issues, five were groundwater findings, 
four concerned waste management, four pertained to TSCA, three were Quality Assurance (QA) issues, three were radiological emissions findings, six concerned industrial wastewater, six pertained to NEPA, and three were environmental monitoring issues. As stated in the DOE's assessment document [Ref. 14], the problems identified do not present an imminent risk to the public health or the environment from continued operation of the plant. The efforts to resolve and close Tiger Team findings are identified in detail in the Pinellas Plant Final Action Plan, Supplement 1 [Ref. 15]. Of the 61 original environmental findings, 52 are certified complete by DOE. The remaining nine are on track with the approved final action plan.

\subsubsection{Technical Safety Appraisal of the Pinellas Plant, February 1992}

A Technical Safety Appraisal was conducted at the Pinellas Plant in February 1992. The environmental portion of the appraisal included environmental surveillance and monitoring, NEPA activities, compliance issues, waste management, and emergency response. The performance in environmental protection was "good" and given a rating of two, where one is superior, two is good, and three is acceptable. There were 18 environmental recommendations generated as a result of the appraisal. An action plan was developed to address the recommendations [Ref. 16]. During 1993, all of the recommendations were implemented.

\subsubsection{Technical Safety Appraisal of the Pinellas Plant, March 1993}

A TSA was conducted at the Pinellas Plant in March 1993. The environmental portion of the appraisal included environmental monitoring, emergency response and spill prevention, NEPA, and waste minimization. The results of the TSA were the best ever at the Pinellas Plant. Environmental was given a rating of one, "superior." The plant is one of only three in the DOE complex to receive an environmental protection rating of "superior" in this program area. The TSA generated two environmental recommendations, as reported in the action plan for 1993 [Ref. 17]. The DOE in conjunction with Specialty Components agreed that neither of these recommendations was a needed or a "value-added" component for Environmental Programs; consequently, no implementation actions were required.

\subsection{Summary of Permits}

\subsubsection{RCRA Permit}

The Pinellas Plant currently possesses a dual RCRA Part B Permit, with the FDEP administering the hazardous waste treatment and storage requirements, and the EPA administering the assessment and remediation 
of solid waste management units. A dual permit was issued because the FDEP does not have EPA authorization to administer the HSWA provisions of RCRA.

Permitted storage for hazardous waste is identified in the Hazardous Waste Facility Permit. Treatment operations include thermal treatment of small charge explosives and chemical treatment of water reactive compounds, such as calcium metal, calcium bimetals, and solid wastes contaminated with lithium metal. The Pinellas Plant conducts all treatment operations in accordance with methodologies detailed or referenced in the plant's Hazardous Waste Facility Permit. Application for renewal of the permit was submitted.

The plant's HSWA Permit, FL6 890090 008, issued by EPA Region IV on February 9,1990, requires the permittee to investigate any releases or potential releases of hazardous waste or hazardous constituents from any SWMU at the plant regardless of the time the waste was placed in the unit. The permit also requires appropriate corrective actions for any releases. This permit requires the permittee to certify annually that hazardous waste generation is minimized to the extent practicable.

\subsubsection{Industrial Wastewater Discharge Permit}

The Pinellas Plant discharges pH-neutralized industrial wastewater and untreated sanitary sewage to the PCSS. The Pinellas County Industrial Wastewater Discharge Permit, 018-IE, was issued on August 28, 1989, and expires August 28, 1994. The plant will submit a wastewater discharge permit renewal application in 1994, according to established regulatory schedules before the current permit expires.

\subsubsection{Stormwater Discharge Permit}

Pinellas Plant personnel sampled two stormwater discharge outfalls and submitted an Individual Stormwater Discharge Permit application in September 1992. A third, previously unknown, outfall was sampled during two representative storm events in 1993, and a revised permit application was submitted to EPA Region IV. The plant has not yet received a stormwater discharge permit, or cornments from EPA on the permit application.

\subsubsection{Air Emissions Permit}

During 1993, the Pinellas Plant operated under Air Construction Permit, AC52-206678, issued on January 7, 1993 by the FDEP. A five-year Air Operating Permit is anticipated early in 1994. 


\subsection{ENVIRONMENTAL PROGRAM INFORMATION}

The Environmental Monitoring Program maintained by the Pinellas Plant is designed to meet the following objectives:

- Determine the effectiveness of treatment and control mechanisms for environmental releases.

- Provide measurements of discharge concentrations for comparison with applicable standards.

- Assess the concentrations of these discharges in the environment.

The environmental effects of plant radiological and nonradiological effluents are minimal, and the facility has implemented a proactive program to ensure compliance with the provisions of all new environmental laws and DOE regulations.

\subsection{Envionmental Monitoring Summary}

\subsubsection{Nonradiological Monitoring}

\section{Arr}

The Pinellas Plant received an Air Emissions Construction Permit, AC52-206678 [Ref. 10]. This permit regulates the quantities of various Volatile Organic Compounds (VOCs) and Organic Compounds (OCs) that the plant may release to the environment through air emissions. Actual VOC/OC emissions for 1993 are reported in Section 5.

The permanent on-site meteorological monitoring station was in service during 1993 and provided excellent data throughout the year. Examples are provided in Tables 1-1 and 1-2.

Water

The Pinellas Plant discharges liquid effluents consisting of sanitary sewage and pH-neutralized industrial process wastewaters to the PCSS. This discharge is regulated under Pinellas County Ordinance No. 91-26 [Ref. 18] and the DOE Pinellas Plant Industrial Wastewater Discharge Permit 018-IE [Ref. 11]. The Pinellas Plant is subject to the effluent limitation guidelines of the Metal Finishing Point Source Category identified in 40 CFR Part 433 developed by the EPA. Where both county standards and national standards apply to a pollutant, the plant complies with the more stringent of the two criteria. As specified in the Pinellas 
Plant Environmental Monitoring Plan [Ref. 1], the industrial, sanitary, and combined wastestreams are sampled to verify permit compliance using PCSS-approved automatic samplers on the following schedule:

- $\mathrm{pH}$ - continuously monitored

- metals - sampled weekly

- cyanide, Total Suspended Solids (TSS) and Biochemical Oxygen Demand (BOD) - sampled monthly

- Total Toxic Organics (TTO) - sampled semiannually

Sample collection and analysis is in accordance with approved methodologies as specified in the industrial wastewater discharge permit.. The plant forwards monthly reports of the monitoring data to the PCSS Industrial Program Manager. Additionally, Pinellas County maintains a sampling station on Pinellas Plant property for periodic, independent verification of compliance

A summary of the average 1993 wastewater discharge concentrations for regulated parameters is shown in Table 5-3 of Section 5. Most parameters are routinely Below Detection Limit (BDL).

Figure 3-1 shows the weekly fluctuation of the copper and zinc components, the only metals with concentrations that exceed the minimum detection limit. Compared with the 1992 data, the copper levels are slightly higher. Zinc has the same average as 1992 , but a lower maximum. The BOD has a wider range, but approximately the same average as 1992. The most significant change is the TTO, which is three times lower than 1992. There were no instances in which the permitted levels were exceeded in 1993. 


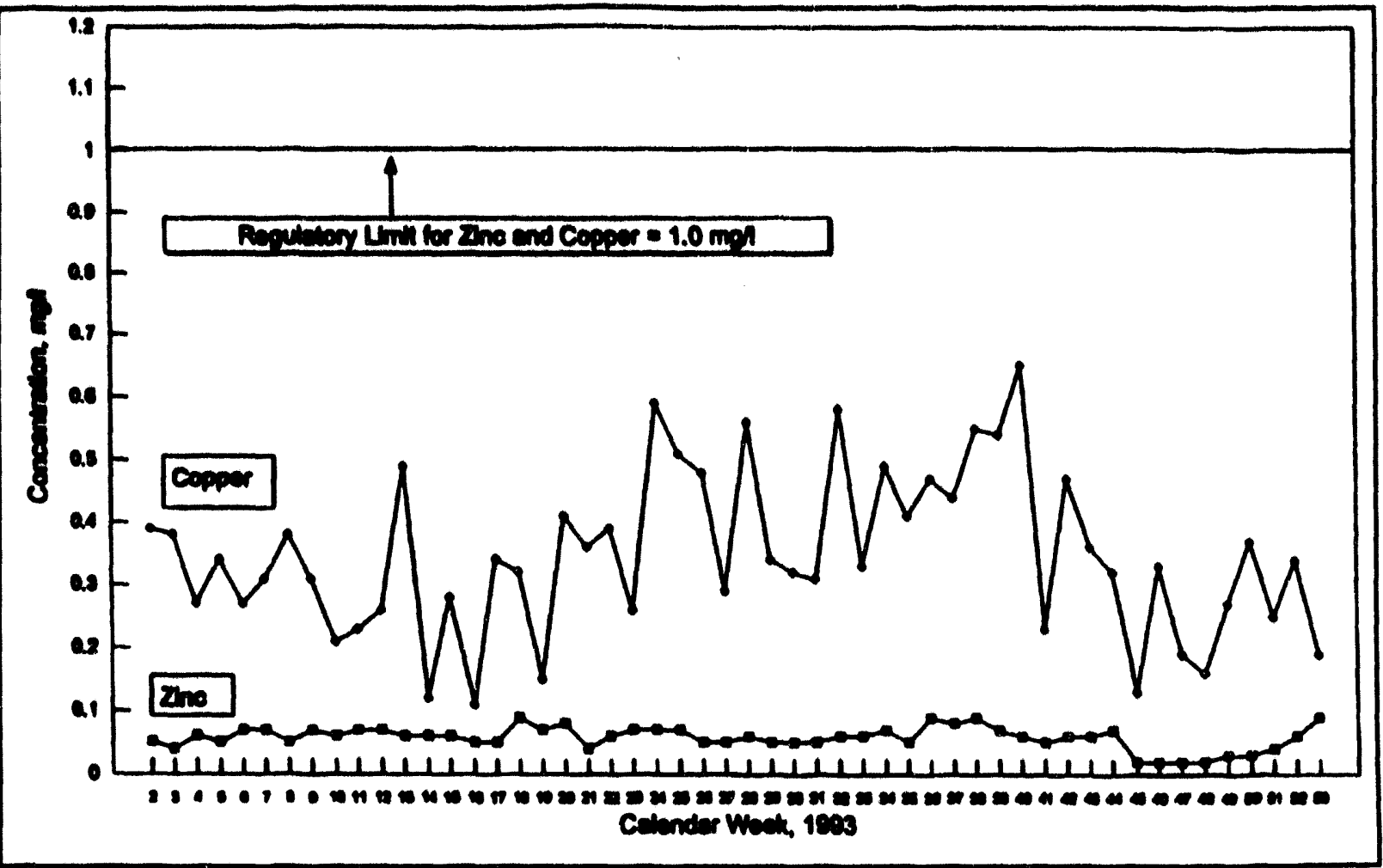

Figure 3-1. Regulated Liquid Effluent Releases Above Detection Limit, 1993

\subsubsection{Radiological Monitoring}

Ar

Small quantities of radioactive tritium and kypton-85 are discharged into the air from plant operations. Four point sources of radiological air emissions are the Building 100 Main Stack, the Building 100 Laboratory Stack, the Building 200 strec, and the Building 800 stack. Two roof openings emit very small amounts of tritium. As specified in the Pinellas Plant Environmental Monitoring Plan, these sources are sampled continuously for tritium to verify compliance with 40 CFR Part 61, Subpart H [Ref. 8] and DOE 5400.5, Radiation Protection of the Public and the Environment [Ref. 3]. Krypton-85 emissions are monitored continuously and are quantified using mass balance calculations. In addition to the stack samplers, there is a network of seven on-site and six off-site air sampling stations. There are no area sources of radiological emissions at the Pinellas Plant. 
Because the plant used a sealed plutonium heat source in the RTO product that was discontinued more than three years ago, the plant continues to sample the ambient air for plutonium. No plutonium was ever released inside the building or to the outside environment, and no plutonium has been measured in air.

Table 3-1. Summary of Air Environmental Monitoring at the Pinellas Plant in 1993

\begin{tabular}{|c|c|c|c|c|}
\hline Location & $\begin{array}{l}\text { Number of } \\
\text { Stattoes }\end{array}$ & $\begin{array}{l}\text { Somple } \\
\text { Colloction } \\
\text { Prequenes }\end{array}$ & $\begin{array}{l}\text { Analyals } \\
\text { Frequeecy }\end{array}$ & Nuellide \\
\hline $\begin{array}{l}\text { Radiological Exhaust } \\
\text { Stacks }\end{array}$ & $\begin{array}{l}2 \\
4\end{array}$ & $\begin{array}{l}\text { Continuous } \\
\text { Continuous }\end{array}$ & $\begin{array}{c}\text { Daily } \\
\text { Monthly }\end{array}$ & $\begin{array}{l}\text { Tritum } \\
\text { Trtitum }\end{array}$ \\
\hline $\begin{array}{l}\text { On-Site Sampling } \\
\text { Stations }\end{array}$ & $\begin{array}{l}7 \\
4\end{array}$ & $\begin{array}{l}\text { Continuous } \\
\text { Continuous }\end{array}$ & $\begin{array}{l}\text { Monthly } \\
\text { Quarterly }\end{array}$ & $\begin{array}{l}\text { Thtium } \\
\text { Plutonium }\end{array}$ \\
\hline $\begin{array}{l}\text { Off-Site Sampling } \\
\text { Stations }\end{array}$ & $\begin{array}{l}6 \\
5\end{array}$ & $\begin{array}{l}\text { Continuous } \\
\text { Continuous }\end{array}$ & $\begin{array}{l}\text { Monthly } \\
\text { Quarterly }\end{array}$ & $\begin{array}{l}\text { Tritum } \\
\text { Plutonium }\end{array}$ \\
\hline
\end{tabular}

A summary of the results of the stack sampling for 1993 is shown in Table 3-2. The results show that radiological emissions at the Pinellas Plant are continuing to decrease from year to year. Results of the on- and off-site sampling stations are presented in Section 4.

Table 3-2. Summary of Total Radiological Stack Emissions (Tritium and Krypton) for 1993

\begin{tabular}{|l|c|}
\hline Source & Anumal Eminsions (curiad) \\
\hline Building 100 Main Stack & 24.82 \\
\hline Building 100 Laboratory Stack & 5.47 \\
\hline Roof Opening 378 & $2.46 \mathrm{E}-3$ \\
\hline Roof Opening 413 & $6.40 \mathrm{E}-4$ \\
\hline Building 200 Stack & BDL (0.007 C) \\
\hline Building 800 Stack & 0.07 \\
\hline Total for 1993 & 30.36 \\
\hline Total for 1992 & 49.7 \\
\hline Total for 1991 & 115 \\
\hline
\end{tabular}




\section{Waste Water}

Small quantities of radioactive tritium are present in the plant's sanitary sewage and industrial wastestreams. Just prior to leaving the IWNF, the sanitary sewage and industrial wastestreams are combined and discharged to the PCSS. As specified in the Pinellas Plant Environmental Monitoring Plan [Ref. 1], a 24-hour composite sample is collected each day of the year from the sanitary, industrial, and combined wastestreams and analyzed for tritium. Table 3-3 presents a summary of the total amount of tritium discharged in the liquid effluent in 1393.

Table 3-3. Tritium Discharged to PCSS, 1993

\begin{tabular}{|c|c|c|}
\hline Parnmeter & $\begin{array}{c}\text { Hi:S Dlecharge } \\
\text { Standard* }\end{array}$ & 1993 Maximum \\
\hline $\begin{array}{c}\text { Average Daily } \\
\text { Concentration, pCi/ml }\end{array}$ & 100,000 & 5.14 (June 12) \\
\hline $\begin{array}{c}\text { Average Monthly } \\
\text { Concentration, pCi/ml }\end{array}$ & 100,000 & 2.86 (July) \\
\hline $\begin{array}{c}\text { Total Annual Quantity } \\
\text { Released, curies }\end{array}$ & 5 & 0.44 \\
\hline $\begin{array}{l}\text {-Florida Administrative Code 10D-91.418, Control of Radiation } \\
\text { Hazards }\end{array}$ \\
\hline
\end{tabular}

\section{Surface Water}

Environmental Management routinely samples the on-site stormwater retention/detention ponds 26 and off-site surface water locations and analyzes them for tritium. The results from 1993 are presented in Section 4.

Soll

All plutonium, with the exception of calorimeter sources and small instrumentation calibration check sources, was removed from the plant in February 1991. In accordance with an agreement with the HRS and as specified in the Pinellas Plant Environmental Monitoring Plan [Ref. 1], the plant continues to collect and analyze soil samples for plutonium annually from two on-site and four off-site locations. The results are presented in more detail in Section 4. There was no plutonium from plant operations detected in soil samples collected in 1993. 


\subsubsection{Groundwater Quality}

The Pinellas Plant monitors groundwater pursuant to requirements stated in DOE 5400.1, Chapter IV, [Ref. 2] and provides evaluations of implemented interim measures and surveillance of potential groundwater contamination sites. These sites include the 4.5 Acre Site and other sites identified in the plant's HSWA Permit. Of the 205 monitoring, recovery and test wells at the plant, approximately $\mathbf{1 5 0}$ are actively monitored either on a quarterly, biannual, or annual basis, dependent on the parameter of interest. Approximately one-half of the wells are sampled and analyzed for tritium quarterly.

Approximately 90 monitoring wells are sampled quarterly and analyzed for VOCs. Approximately $\mathbf{5 0}$ and $\mathbf{9 0}$ monitoring wells are sampled and analyzed for semivolatiles (phenol compounds) and trace metals respectively. Specialty Components Environmental Management submits all raw data in a groundwater quarterly report to DOE/PAO. In addition, Specialty Components Environmental Management summarizes monitoring data associated with sites undergoing interim measures and reports to DOE/PAO for transmittal to FDEP and EPA.

During 1993, groundwater sampling at the plant site included field measurements for $\mathrm{pH}$, conductivity, and temperature. Some split samples were sent to an on-site analytical laboratory for volatile organic analyses confirmation. Table 3-4 presents a summary of all groundwater data collected during 1993. Data associated with field measurements is presented in Section 6, Groundwater Protection Program. Table 3-4 identifies each chemical constituent with its corresponding standard, if any, the anasytical detection limit, the frequency of detection, and the maximum value detected. The primary constituents of concern at the plant include solvent compounds and their decomposition products such as vinyl chloride, trichloroethylene, dichloroethylene, benzene, and dichloromethane. 
Table 3-4. Summary of Groundwater Monitoring Results, $\mu \mathrm{g} /$

\begin{tabular}{|c|c|c|c|}
\hline Parnmeter & Standard" & Prequency & Maximum \\
\hline \multicolumn{4}{|l|}{ Trace Elements } \\
\hline Arsenic & 50 & $0 / 178$ & 31 \\
\hline Cadmium & 10 & $0 / 178$ & 9 \\
\hline Chromium & 50 & $1 / 178$ & 60 \\
\hline Iron & 300 & $164 / 178$ & 720,000 \\
\hline Lead & 50 & $1 / 178$ & 140 \\
\hline Manganese & 50 & $17 / 178$ & 2,600 \\
\hline \multicolumn{4}{|l|}{ Volatiles } \\
\hline 1,1-Dichloroethane & $\mathbf{N} / \mathbf{S}$ & 346 & 39 \\
\hline 1,2-Dichloroethylene & 70 & $32 / 346$ & 26,000 \\
\hline Benzene & 1.0 & $29 / 346$ & 100 \\
\hline Chloroethane & $\mathbf{N} / \mathbf{S}$ & 346 & 1,300 \\
\hline Dichloromethane & $5(\mathrm{P})$ & $25 / 346$ & $3,200,000$ \\
\hline Toluene & 1,000 & $5 / 346$ & 14,000 \\
\hline Trichloroethene & 3.0 & $6 / 346$ & 43,000 \\
\hline Vinyl Chloride & 1.0 & $68 / 346$ & 19,000 \\
\hline \multicolumn{4}{|c|}{$\begin{array}{l}\text { SDWA - Maximum Contaminant Level and/or FDEP Primary Drinking Water Standards in ug/ unless other- } \\
\text { wise denoted } \\
\text {-0 The number of samples exceeding the standard/the total number of samples analyzed } \\
\text { (P) = indicates a proposed standard } \\
\text { N/S = no standard }\end{array}$} \\
\hline
\end{tabular}

\subsection{Compliance with the NEPA}

The Pinellas Plant routinely completes draft NEPA documents for plant processes and project developments that require NEPA documentation and transmits them to DOE for review and final action. Martin Marietta Corporate audits, DOE Technical Safety Appraisals and internal audits, and self-assessments ensure that the plant complies fully with NEPA.

The NEPA documentation process is initiated early in the project planning process through meetings with facility personnel to discuss the nature, cost, scope, and proposed timing of project implementation. The plant performs NEPA documentation status tracking using a computerized data base. The plant completes a standardized two-page checklist describing the planned project, its potential impacts on the environment, and the applicable regulatory and permitting requirements. After internal review, the plant transmits the checklist to DOE and drafts additional DOE documentation, as needed, based on DOE determinations. Table 3-5 is a summary of existing NEPA documentation. 
Table 3-5. NEPA Documentation as of December 31, 1993

\begin{tabular}{|c|c|c|}
\hline (4) & $\begin{array}{l}\text { NEPA } \\
\text { Action }\end{array}$ & $\begin{array}{l}\text { Action } \\
\text { Date. }\end{array}$ \\
\hline Replace Area 192 Degreaser & $C X$ & $4 / 15 / 93$ \\
\hline Rerack SE 1076 Tester/provide pwr drops & $\mathrm{CX}$ & $4 / 15 / 93$ \\
\hline Installation of Vacuum Oven Area 1635 & $\mathbf{C X}$ & $5 / 1 / 93$ \\
\hline Increase Argon Gas Pressure for Robotic Blowoff & $\mathbf{C X}$ & $5 / 1 / 93$ \\
\hline Pemove interlock on "CM" Fumace Door & $\mathbf{C X}$ & $5 / 1 / 93$ \\
\hline Replumb acetylene gas pressure regulators & $\overline{C X}$ & $5 / 1 / 93$ \\
\hline Start development of Tritium Loader \#1 & $\mathbf{C X}$ & $5 / 1 / 93$ \\
\hline Relocate and install hood & $\overline{C X}$ & $5 / 1 / 93$ \\
\hline Install fire hose dryer, Bldg. 700 & $C X$ & $5 / 19 / 93$ \\
\hline Relocate chemical exhaust hood from 195 to 316 & $\mathbf{C X}$ & $5 / 24 / 93$ \\
\hline Develop contact assembly process for A111A & $\mathbf{C X}$ & $5 / 24 / 93$ \\
\hline Setup WR-Qualified rod fabrication line & $\overline{C X}$ & $5 / 24 / 93$ \\
\hline Restart of wet machining of PbOx Ceramics & $\mathbf{C X}$ & $5 / 24 / 93$ \\
\hline Add cltrate cleaning step & $C X$ & $5 / 24 / 93$ \\
\hline Restart PC board process in A103B, E, F & $c x$ & $5 / 24 / 93$ \\
\hline Water/akcohol to replace Fluorinert & $C X$ & $5 / 24 / 93$ \\
\hline Demilitarize/sanltize neutron generator & $\mathrm{CX}$ & $5 / 25 / 93$ \\
\hline Develop contact assembly process Area 111A & $\mathrm{CX}$ & $6 / 5 / 93$ \\
\hline Replace hydroform fittings & $C X$ & 6/6/93 \\
\hline Replace arbor press saw for support for project & $\mathbf{C X}$ & $6 / 7 / 93$ \\
\hline Room modifications to install aqueous degreaser & $\mathrm{CX}$ & $6 / 7 / 93$ \\
\hline Add sprinkler system & $c x$ & $6 / 15 / 93$ \\
\hline Remove and Excess Spray Dryer A192 & $c x$ & $6 / 17 / 93$ \\
\hline Remove alcohol bath from A139 & $\overline{C X}$ & $06 / 17 / 93$ \\
\hline Hydrogen flow control manifold installation & $C X$ & $6 / 17 / 93$ \\
\hline Lower hydrogen gas regulator valves & $\mathbf{C X}$ & $6 / 17 / 93$ \\
\hline Replace MEK with acetone for cleaning A111C, D & CX & $6 / 17 / 93$ \\
\hline Excess foam dispenser from A139 & $\mathbf{C X}$ & $6 / 17 / 93$ \\
\hline Scrap hysol dispenser A139 & $C x$ & $6 / 17 / 93$ \\
\hline Excess Batch mix dispenser A139 & $6 x$ & $6 / 17 / 93$ \\
\hline Thermocouple change in hydrogen furnace & $\mathrm{CX}$ & $6 / 17 / 93$ \\
\hline Install acetylene gas sensors A139E & $\overline{C X}$ & $6 / 17 / 93$ \\
\hline $\begin{array}{ll}\text { EA } & \text { Environmental Assessment } \\
\text { CX } & \text { Categorical Exclusion } \\
\text { TRS } & \text { Tritium Recovery System }\end{array}$ & & \\
\hline
\end{tabular}




\begin{tabular}{|c|c|c|}
\hline Project $\quad$ ( & \begin{tabular}{|l|} 
NEPA \\
Action
\end{tabular} & $\begin{array}{l}\text { Action } \\
\text { Date }\end{array}$ \\
\hline Install four additional on-site tritium monitors & $\mathrm{CX}$ & $6 / 17 / 93$ \\
\hline Emergency notfication PA system & $\overline{C X}$ & $6 / 17 / 93$ \\
\hline Relocate chemical exhaust hood from A195 to A316 & $\overline{C X}$ & 6/17/93 \\
\hline Addition of liquid nitrogen line in A350S & $\overline{C X}$ & $6 / 17 / 93$ \\
\hline Redesign wiring on hood scrubber assombly & $\overline{C x}$ & 6/17/93 \\
\hline Compressed air dryers & $\overline{C x}$ & $6 / 17 / 93$ \\
\hline Diesel pipe upgrade project & $\mathbf{C X}$ & $6 / 17 / 93$ \\
\hline Micromatic saw hookup & $\overline{C X}$ & $6 / 17 / 93$ \\
\hline Repair loak In LI/SOC12 Lamb Coll & $\overline{c x}$ & $6 / 17 / 93$ \\
\hline Relocate leak detector & $\overline{C X}$ & $\longdiv { 7 / 0 1 / 9 3 }$ \\
\hline Relocate mass spectrometer/Glove boxes and inlet system & $\overline{C X}$ & $7 / 01 / 93$ \\
\hline Move thermal desorption system & $\overline{C x}$ & $7 / 01 / 93$ \\
\hline Removal of film processor & $\overline{c x}$ & $7 / 01 / 93$ \\
\hline Temporary heat powder processing & $\overline{c x}$ & $7 / 06 / 93$ \\
\hline Move acetylene gas cylinders/plumbing to Flame Spray & $\overline{C X}$ & $7 / 07 / 93$ \\
\hline Start LAC subassembly process & $\overline{C X}$ & $7 / 07 / 93$ \\
\hline Flammable liquid storage tank & $\overline{c x}$ & $7 / 107 / 93$ \\
\hline Locate MC2993 target removal to Area 108 & $\overline{C X}$ & $7 / 08 / 93$ \\
\hline Premix of acid for passive components & $\overline{c x}$ & $7 / 12 / 93$ \\
\hline Installation/Restart of digital looper & $\overline{c x}$ & $7 / 12 / 93$ \\
\hline Ground water sampling & $\overline{C X}$ & $7 / 13 / 93$ \\
\hline Additional cooling coll to dry room & $\overline{c x}$ & $7 / 13 / 93$ \\
\hline Reroute TRS piping and cap roof penetration & $\overline{C X}$ & $7 / 21 / 93$ \\
\hline Replacing additional TRS piping sections & $\widehat{c x}$ & $7 / 22 / 93$ \\
\hline Northwest industrial liftstation upgrades & $\overline{C x}$ & $8 / 06 / 93$ \\
\hline Electrical discharge machine wiring & $\overline{C X}$ & $8 / 24 / 93$ \\
\hline Add additional main radiological stack monitor & $\overline{C X}$ & $8 / 24 / 93$ \\
\hline Disposal of oven door w/asbestos and oven removal & $\overline{C X}$ & $8 / 24 / 93$ \\
\hline Modify/repair elevated plattorms & $\overline{C X}$ & $8 / 24 / 93$ \\
\hline Change stack exhaust systems & $\overline{C X}$ & $8 / 24 / 93$ \\
\hline Add front end fire alarm systems & $\overline{C x}$ & $8 / 214 / 93$ \\
\hline Add sampling ports to Main and Lab stacks & $\overline{C x}$ & $8 / 24 / 93$ \\
\hline Relocate ultrasonic equipment & $\overline{C X}$ & $8 / 24 / 93$ \\
\hline $\begin{array}{l}\text { EA Environmental Assessment } \\
\text { CX Categorical Exclusion } \\
\text { TRS } \\
\text { Tritium Recovery System }\end{array}$ & & \\
\hline
\end{tabular}




\begin{tabular}{|c|c|c|}
\hline Project & $\begin{array}{l}\text { NEPA } \\
\text { Action } \\
\end{array}$ & \begin{tabular}{|l|} 
Action \\
Date \\
\end{tabular} \\
\hline LAC rearrangement acthilties & CX & $8 / 24 / 93$ \\
\hline Electrical bus duct relocation & $\mathbf{C X}$ & $8 / 24 / 93$ \\
\hline Routine Environmental Restoration/WM acthities 1994 & $\overline{C X}$ & $8 / 26 / 93$ \\
\hline Equipment water overflows & $\mathbf{C X}$ & $9 / 01 / 93$ \\
\hline Pinellas Plant Consolidation Initiative & $\mathbf{C X}$ & $9 / 01 / 93$ \\
\hline Install aqueous solvent cleaning bench & $\mathbf{C X}$ & 9/09/93 \\
\hline Optical emissions spec removal/aser plasma inst. & $\overline{C X}$ & $9 / 09 / 93$ \\
\hline Add backup pumping capabillty to NW Ifitt station & $\overline{c x}$ & $9 / 09 / 93$ \\
\hline Add pressure/vacuum vent & $\overline{C X}$ & $9 / 09 / 93$ \\
\hline Add pH neutralization of HP waste water & $C x$ & $9 / 09 / 93$ \\
\hline Area 176 alterations & $C x$ & $9 / 09 / 93$ \\
\hline Flow monitor installation & $\overline{C X}$ & $9 / 09 / 93$ \\
\hline Tracetek moisture monitor & $C x$ & $9 / 09 / 93$ \\
\hline Filter system, exhaust, shower modifications & $\mathbf{C X}$ & 9/22/93 \\
\hline Removal of damaged asbestos material & $\mathbf{C X}$ & 8/22/93 \\
\hline$N$ sitheast Site well field configuration & $\overline{C X}$ & $9 / 27 / 93$ \\
\hline Replacement of 4.5 Acre Site remediation site press & $\mathbf{C X}$ & 9/27/93 \\
\hline Preventive Maintenance on West Manhole sump pumps & $\overline{c x}$ & $10 / 01 / 93$ \\
\hline Replace sprinkler system No. 11 & $\mathbf{C X}$ & $10 / 15 / 93$ \\
\hline Install central AC in Area 153 EOC & $\overline{C X}$ & $10 / 15 / 93$ \\
\hline Reduce exhaust system capacity to serve chem hoods & $\mathbf{C X}$ & $10 / 17 / 93$ \\
\hline Revise DI water operations for HCl delivery & $\mathbf{C X}$ & $10 / 17 / 93$ \\
\hline Replace asbestos dessicant wheel & $c x$ & 10/17/93 \\
\hline Conversion of Bullding 400 & $\overline{C X}$ & $10 / 17 / 93$ \\
\hline Reduction of PFN Tank and oll disposal & $\overline{C x}$ & $10 / 17 / 93$ \\
\hline Regrade and gravel road around Bldg. 900 & $\mathrm{CX}$ & $10 / 17 / 93$ \\
\hline Relocate $X$-ray equipment 176B to 161B & $\overline{C X}$ & $10 / 21 / 93$ \\
\hline Removal of damaged asbestos & $\mathbf{c x}$ & $10 / 25 / 93$ \\
\hline Addition of fire training prop at Bldg. 900 & $\mathbf{C X}$ & $10 / 27 / 93$ \\
\hline Leasing of Buildings 400 and 1400 & $\mathrm{CX}$ & $10 / 29 / 93$ \\
\hline Temporary attachment of $\mathrm{H} 2$ cylinders to workstations & $\overline{C x}$ & $11 / 22 / 93$ \\
\hline Replace TRS converter with modified converter & $\mathrm{CX}$ & $11 / 29 / 93$ \\
\hline Rearrange support pad Area 139 & $\overline{C X}$ & $12 / 01 / 93$ \\
\hline $\begin{array}{ll}\text { EA } & \text { Environmental Assessment } \\
\text { CX } & \text { Categorical Exclusion } \\
\text { TRS } & \text { Tritium Recovery System } \\
\end{array}$ & & \\
\hline
\end{tabular}




\begin{tabular}{|c|c|c|}
\hline Project & \begin{tabular}{|l|} 
NEPA \\
Action
\end{tabular} & $\begin{array}{l}\text { Action } \\
\text { Date }\end{array}$ \\
\hline Polymer lab relocation & CX & $12 / 02 / 93$ \\
\hline Generator consolidation & $\overline{C x}$ & $12 / 13 / 93$ \\
\hline Area 1161 conversion for off-site material storage & $C X$ & $12 / 13 / 93$ \\
\hline Remove H2 deadlegs, install H2 flowmeter & $\overline{c x}$ & $12 / 14 / 93$ \\
\hline Relocate Faxitron X-ray system in A114 & $\overline{c x}$ & $12 / 14 / 93$ \\
\hline Relocate equipment from A182 to 107/108 & $\overline{c x}$ & $12 / 14 / 93$ \\
\hline Remove guard house and escort building from roof & $\overline{C x}$ & $12 / 14 / 93$ \\
\hline Replace chilled condenser/water valves & $\overline{C X}$ & $12 / 14 / 93$ \\
\hline Rearrange Area 107 office layout & $c x$ & $12 / 14 / 93$ \\
\hline Remove exhaust hood in Area 108 & $\overline{C X}$ & $12 / 14 / 93$ \\
\hline Eliminate iridlte rinse water & $\overline{C X}$ & $12 / 14 / 93$ \\
\hline Remove hi-pot tests from Area 131 & $\overline{C x}$ & $12 / 14 / 93$ \\
\hline Inspection of chemical floor drains/pipes & $\overline{C x}$ & $12 / 14 / 93$ \\
\hline Install additional controls on downflow area & $\overline{C x}$ & $12 / 14 / 93$ \\
\hline Rearrange support pad Area 1391 & $\overline{c x}$ & $12 / 14 / 98$ \\
\hline Relocate equipment from A182 to $107 / 108$ & $\overline{c x}$ & $12 / 16 / 98$ \\
\hline Northeast Site Interim Corrective Measures & EA & Pending \\
\hline Surficial Aquifer & EA & Pending \\
\hline Commercialization of the Pinellas Plant & EA & Pending \\
\hline $\begin{array}{|ll|}\text { EA } & \text { Environmental Assessment } \\
\text { CX } & \text { Categorical Exclusion } \\
\text { TRS } & \text { Tritium Recovery System } \\
\end{array}$ & & \\
\hline
\end{tabular}

\subsection{Significant Environmental Activities}

\subsubsection{Pollution Abatemen'.}

\section{Nonhazardous Waste Treatment}

Specialty Components Environmental Management provided the PCSS a procedure and letter explaining plans to discharge effluent to the POTW from the new nonhazardous treatment system. The treatment system reduces the volume of nonhazardous waste shipped off-site for disposal. The PCSS approved discharge of the effluent pending installation of a discharge flow meter. Installation of the flow meter and initiation of treatment are expected in early 1994. 


\section{Health Physics Drain Replacement}

The Health Physics Drain System at the Pinellas Plant conveys wastewater from the tritium processing areas of the plant to the IWNF. This wastewater may therefore contain tritium. Underground sections of this drain system are being replaced with aboveground piping with secondary containment. The underground sections will be flushed and filled with grout to prevent further use. This will prevent the potential for groundwater contamination from underground leaks and allow accessibility for inspections and repairs of aboveground piping.

\section{Delonized Water Recycling}

Good quality wastewater from the Deionized Water Treatment System was re-routed from disposal into the chemical drain system to the cooling water towers for reuse as make-up water. This recycles water, reduces the plant sewer bill and minimizes the amount of water needed from the county municipal water system. This has resulted in recycling of approximately 18 million gallons of water per year with a net savings of $\$ 50,000$ annually.

\section{Re-routing of Furnace Cooling Water}

The emergency cooling water overflow discharge from two hydrogen furnaces was re-routed from the plant stormwater drainage system to the plant chemical drain system. This prevents potential discharge of non-contact cooling water into the stormwater. Cooling water from the two fire protection pump diesel engines will be re-routed from storm drain discharge to the IWNF in 1994.

\section{Blomedical Waste Program}

As the result of an internal audit, conducted by Specialty Components, a comprehensive biohazardous waste management program was developed, implemented and continues to be maintained. This program ensures administrative and operational compliance with OSHA, DOT and HRS rules, regulations and policies. The program includes written training programs, operating plans and procedures and off-site treatment and disposal facility inspections. The program exceeds all regulatory requirements and employs best management practices. 


\section{Direct Discharge of Health Physics Tanks}

There are three 10,000 gallon Health Physics holding tanks at the IWNF. These tanks collect wastewater with low concentrations of tritium. After sampling and analysis of the tank contents for tritium and comparing the results to the plant ALARA objective, the tanks are discharged through the IWNF to the PCSS along with the industrial wastewater and sanitary sewage. The sludge that collects in the bottom of the IWNF neutralization tank is a listed hazardous waste (FOO6, electroplating sludge). Since this sludge has the potential to contain minute concentrations of tritium, a project was initiated to direct the Health Physics wastewater discharge to the PCSS after neutralization. This redirection will mitigate the potential to generate mixed waste. This project design began in 1993 and completion is expected in the summer of 1994.

\subsubsection{Special Studies}

\section{Tritium Monitoring}

The plant implemented improvements in the sampling equipment and sampling procedures for ambient tritium sampling stations in 1993. These improvements resulted in better quantification of on- and off-site ambient tritium air concentrations. The plant will add four new on-site tritium sampling stations in 1994 to significantly improve quantification of fenceline concentration of tritium.

\subsection{Assesements}

The Pinellas Plant must comply with Federal, State, and local regulations. External and internal oversight, as well as self-assessments helps ensure compliance.

Internal oversight is by organizations such as the Environmental Oversight and Quality Assurance function of the Environmental, Safety and Health Division, and by the Quality Appraisal and Assessment Department of the Quality Assurance Division. Any noncompliance findings require the development and implementation of a corrective action plan. In addition, Martin Marietta Corporate Environmental Management provides oversight through routine site audits.

Self-assessments are conducted by employees within Environmental Restoration and Permitting, and Waste Management. These self-assessments include assessments of Specialty Components and external contractor personnel 
performing sampling and maintenance activities. Corrective actions resulting from these self-assessments are used to improve the Environmental Monitoring Program, and are documented and retained as quality assurance records.

External oversight is provided by the PAO, $\mathrm{Al}$, and DOE Headquarters personnel, and by Federal, State, and local regulatory agencies. Any noncompliance findings require the development and implementation of a corrective action plan, quarterly status reports, and formal close-out procedures to ensure that the nonconforming item is corrected.

The Pinellas Plant's Environmental Management Assessment Program is implemented plantwide to assure compliance with all laws and regulations. These Specialty Components Environmental Management assessments focus on issues such as hazardous waste container identification, satellite accumulation, radioactive waste, scrap metal management, radioactive and nonradioactive air and wastewater effluents and NEPA. During 1993, assessments were performed by Specialty Components Environmental Management on 59 manufacturing and engineering areas. Where needed, corrective actions were implemented by the area owners and verified by Specialty Components Environmental Management.

\subsection{Rollution Prevention and Waste Minimization}

Pollution prevention and waste minimization requires a thorough understanding of the raw material inputs and waste products for all processes at the Pinellas Plant. To provide this information, a Process Waste Assessment team assesses processes that generate large amounts of hazardous waste. The Process Waste Assessment team determines the areas that generate the largest wastestreams and implements waste minimization and pollution prevention practices. Process waste assessments are an ongoing activity at the plant. The primary activity in 1993 involved efforts to reduce the trichloroethylene wastestream from the Area 143 vapor degreaser. Other on-going pollution prevention and waste minimization programs include:

- Plantwide aluminum can recycling program (proceeds go to nonprofit environmental organizations).

- Sale of scrap metal and cardboard.

- Off-site solvent reclamation.

- Replacing chlorinated solvents with aqueous degreasers.

- Solid sanitary waste managed by a commercial recycling firm.

- On-site treatment of machine cutting fluid $(10,000$ gallons per year waste reduction).

- A plantwide office paper recycling program. 
- A laser printer cartridge recycling program.

- Waste minimization/pollution prevention awareness training.

Studies are also continuing to minimize or replace the halogenated solvents remaining in the manufacturing processes.

\subsection{Reportsand Certifications}

The Pinellas Plant's Environmental Management organization is responsible for ensuring that all reports and certifications required by Federal or State regulations or DOE Orders are completed as required. The plant submitted the 1993 Waste Generation/Disposal Summary Report to the PCSS in January 1994. This report is required by the plant's Wastewater Discharge Permit. The plant also submitted quarterly reports on the results of the Wastewater Monitoring Program to the PCSS in 1993. No permit limits were exceeded in 1993. The plant will submit monthly instead of quarterly reports to the PCSS in 1994.

Shipments of hazardous waste originating from the plant must be accompanied by a uniform hazardous waste manifest. This manifest requires the generator of the waste to certify that packaging, marking, and labeling comply with DOT regulations for hazardous material transportation, and that the facility has a program in place to reduce the volume or toxicity of waste generated to the lor rest practicable levels.

The FDEP also requires generators of waste to complete a generator's biennial report on the types and amounts of hazardous waste treated, stored, and disposed of. The 1993 Annual Waste Report to the EPA was submitted March 1, 1994.

\subsection{Troining}

Training is a high priority activity at the Pinellas Plant. All Pinellas Plant employees must participate in a hazard communication program meeting OSHA requirements and tailored to the types of chemicals used by the employee. This annual program provides guidance and information such as protective clothing, routes of exit, emergency spill procedures, fire prevention procedures, and waste disposal procedures. Approximately 1,000 employees have received training in waste minimization and pollution prevention awareness. Also, approximately 500 plant personnel who handle hazardous waste complete computer-based training in RCRA regulations, which ensures compliance awareness and defines specific employee responsibilities.

Representative members of Waste Management and Environmental Restoration and Permitting received extensive training in hazardous material transportation (49 CFR), hazardous material response (29 CFR), and protection of the environment (40 CFR). 
Most Hazardous Materials response team members receive additional training beyond the 40-hour initial and 8-hour annual refresher training required by OSHA. These employees attend emergency response training with the local fire department and participate in on-site monthly exercises and drills. They also attend additional training to qualify for various team responsibilities to include: specialist, technician, and incident commander. 


\section{ENVIRONMENTAL RADIOLOGICAL PROGRAM INFORMATION}

The Radiological Monitoring Program includes sampling air and water for tritium and air, water, and soil for plutonium, both on-site and in the environment surrounding the Pinellas Plant. Impacts to the public and the environment from plant operations are determined from a monitoring program information data base.

Tritium has a half-life (how long it takes for half the amount to be removed by radioactive decay) of 12.3 years. Krypton-85 has a half-life of 10.7 years. Tritium can exist in the gas and oxide or vapor state. Tritium in the oxide state behaves like water chemically and is readily exchanged with water in the body. Because of this, tritium oxide is greater than 10,000 times more biologically reactive than tritiun gas. However, since water is excreted readily by the body, tritium oxide has a biological half-life, or how long it takes for half of the tritium to be eliminated from the body, of 4 to 18 days. Krypton-85 exists only in the gaseous state. Plutonium-238 has a half-life of 90 years and Plutonium-239 has a half-life of 24,000 years.

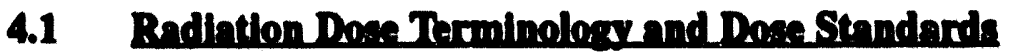

Absorbed Dose--The measure of dose or exposure to ionizing radiation to an organ of the body is the absorbed dose. It is defined as the quantity of radiation energy absorbed by an organ divided by its mass. The International System of Units (SI) unit of absorbed dose is the gray. A gray is equal to 1 joule per kilogram of organ mass. A gray is equal to 100 rad; therefore, 1 rad is an amount of absorbed energy equivalent to one hundredth of a joule. Since the absorbed dose does not incorporate the biochemical effects of differing types of ionizing radiation, the absorbed dose is inadequate for predicting health effects associated with exposure to radiation.

Dose equivalent--The dose equivalent to an organ exposed to a source of ionizing radiation is the absorbed dose to the organ multiplied by a quality factor of 1 for gamma radiation and beta particles, and 20 for alpha particles. The dose equivalent is expressed in units of rem or sievert.

Becquerel $(\mathbf{B q})$--A unit of radioactivity defined as 1 disintegration per second. A curie $(\mathrm{Ci})$ of activity is equal to $3.7 \mathrm{E}+10 \mathrm{~Bq}$.

Sievert (Sv)--A unit of dose equal to $100 \mathrm{rem}$. One rem $=0.01$ sievert.

Dose Conversion Factor for Tritlum Oxide-The 50-year committed effective dose equivalent is $2.56 \mathrm{E}-11 \mathrm{~Sv} / \mathrm{Bq}(9.5 \mathrm{E}-08 \mathrm{mrem} / \mathrm{pCi})$ from inhalation, and 1.7E-11 Sv/Bq (6.3E-10 mrem/pCi) from ingestion.

Collective (Population) Dose-The term "collective (population) dose" refers to the sum of the individual doses received by all members of the population.

Committed Dose-An individual's "committed dose" refers to the total dose resulting from an intake that has accumulated over the individual's projected lifetime. In mathematical models, a 50-year time period is used to calculate committed dose. 
Derived Concentration Guide (DCG)--The concentration of radionuclide in air or water that under conditions of continuous exposure for one year by one exposure mode such as ingestion of water, submersion in air, or inhalation, would result in an effective dose equivalent of $100 \mathrm{mrem}(1 \mathrm{mSv})$ [Ref. 3].

Efrective Dose Equivalent--The effective dose equivalent cr nbines dose equivalents received by all organs of the body into a weighted average that is related to an individual's total risk of experiencing health effects. Weighting factors are determined for the health effects of radiation on each organ based on statistical averages for large populations.

These weighting factors are 0.25 for gonads, 0.15 for breast, 0.12 for red bone marrow, 0.12 for lung, 0.03 for thyroid, 0.03 for bone surfaces, and 0.30 for the remaining organs of the body. The effective dose equivalent combines inclividual organ doses into a single number which can be added to summarize the impacts of multiple radionuclides and radiation from internal and external sources.

Monitoring--The direct in-situ sensing of a media (air, water, soil) for constituent concentration.

Reference Man--A hypothetical aggregation of human physical and physiological characteristics arrived at by international consensus. A "reference man" is assumed to inhale 8400 cubic meters of air and ingest 730 liters of water per year.

Sampling--The collection of a representative portion of a media (air, water, soil) that is transported to another location to be analyzed for constituent concentration.

\subsection{Radioactive Emuent Data}

\subsubsection{Alr}

Small quantities of tritium and kypton-85 are released to the air from operations at the plant through four radiological exhaust stacks: the Building 100 Main and Laboratory Stacks, the Building 200 Stack, and the Building 800 Stack (Figure 4-1). The Specialty Components Environmental Management sampled the discharges from these stacks continuously for tritium during 1993. Discharges from two roof openings 378 and 413 were measured during a one-month period in November 1993. Krypton-85 is discharged only through the Building 100 Main Stack, and is monitored by ionization chamber instrumentation. The results of the stack and roof opening effluent sampling are presented in Table 4-1. The monthly stack release data is plotted in Figure 4-2. 


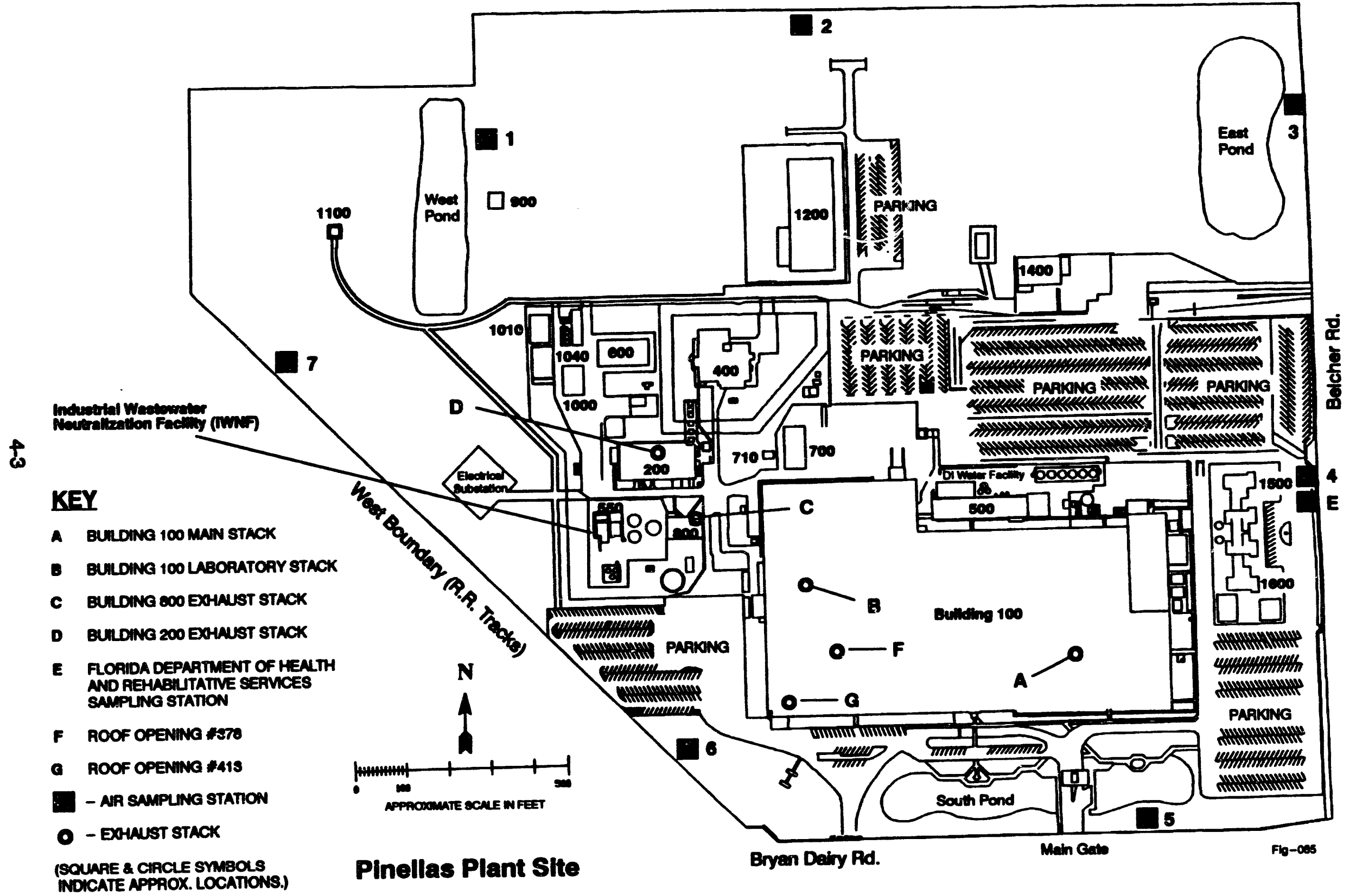

Figure 4-1. On-Site Exhaust Stack and Ambient Air Sampling Station Locations 
Table 4-1. 1993 Stack Releases to the Atmosphere

\begin{tabular}{|l|l|l|}
\hline Release Polnt & Radloneclide & \multicolumn{2}{|c|}{ Activity, Cl (Eq) } \\
\hline Bldg. 100 Main & Tritium gas \& oxide & 6.08 (2.25E+11) \\
\hline Bldg. 100 Main & Krypton-85 & $18.74 \quad(6.93 E+11)$ \\
\hline Bldg. 100 Lab & Tritium gas \& oxide & $5.47(2.02 E+11)$ \\
\hline Roof Opening 378 & Tritium gas \& oxide & $0.00246(9.1 E+07)$ \\
\hline Roof Opening 413 & Tritium gas \& oxide & 0.00064 (2.3E+07) \\
\hline Bldg. 200 & Tritium gas \& oxide & Below detection limit* \\
\hline Bldg. 800 & Tritium gas \& oxide & 0.07 (2.59E+09) \\
\hline Total Emissions & & 30.36 (1.12E+12) \\
\hline - Detection Limit is approx. .006 curies from the Bldg. 200 stack. \\
\hline
\end{tabular}

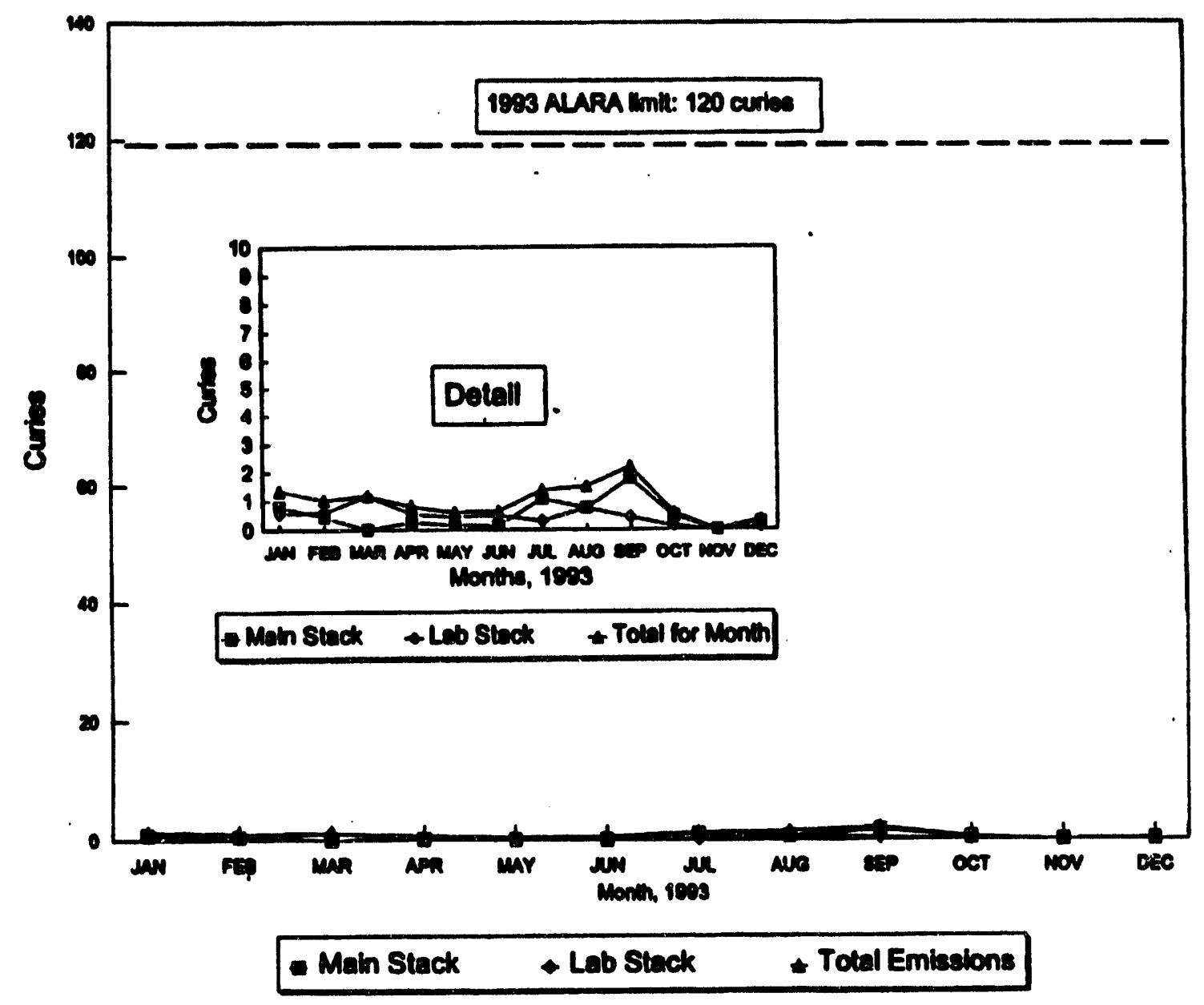

Figure 4-2. Tritium Stack Emissions, 1993 
The cumulative total of tritium stack emissions for 1993 is significantly lower (11.62 curies) than that reported for 1992 (49.7 curies) or 1991 (115 curies). This reduction is a primary result of the decreased neutron generator production in 1993.

\subsubsection{Water}

Small quantities of tritium and very small quantities of naturally occurring uranium are present in the plant's wastewater discharge from the IWNF to the PCSS. The plant collects a 24-hour composite sample every day of the year from the sanitary, industrial, and combined wastestreams at the IWNF (Figure 4-1) and analyzes the sample for tritium, as required by the Pinellas Plant Environmental Monitoring Plan [Ref. 1]. Table 4-2 presents a summary of the tritium discharges for each month of 1993. The data demonstrates that the average monthly and total annual discharges are well below the Florida Administrative Code regulatory discharge limits of $1.0 \mathrm{E}+05 \mathrm{pCi} / \mathrm{ml}$ concentration and 5 curies total annual quantity released.

Table 4-2. Tritium Released in the Combined Wastestream to the PCSS in 1993

\begin{tabular}{|l|c|c|}
\hline \multicolumn{1}{|c|}{ Momth } & $\begin{array}{c}\text { Avernge Dally } \\
\text { Activity, p Cl/mi }\end{array}$ & $\begin{array}{c}\text { Total Tritum } \\
\text { Discharged, } \\
\text { Curies }\end{array}$ \\
\hline January & 1.26 & 0.03 \\
\hline February & 0.88 & 0.02 \\
\hline March & 0.48 & 0.01 \\
\hline April & 0.73 & 0.02 \\
\hline May & 1.19 & 0.03 \\
\hline June & 2.56 & 0.05 \\
\hline July & 2.86 & 0.07 \\
\hline August & 2.41 & 0.05 \\
\hline September & 2.34 & 0.06 \\
\hline October & 1.83 & 0.04 \\
\hline November & 1.34 & 0.03 \\
\hline December & 0.81 & 0.02 \\
\hline Total 1993 & 1.56 & 0.43 \\
\hline
\end{tabular}

Discharges of naturally occurring uranium from a batch manufacturing operation in 1993 were calculated to be $4.0 \mathrm{E}-12 \mu \mathrm{Ci} / \mathrm{ml}(1.5 \mathrm{E}-7 \mathrm{~Bq} / \mathrm{ml})$, which is well below the sanitary sewer discharge standard of 9.0E-04 $\mu \mathrm{Ci} / \mathrm{ml}$ and $1.0 \mathrm{E}-03 \mu \mathrm{Ci} / \mathrm{ml}$ for $\mathrm{U}-234$ and $\mathrm{U}-238$, respectively. 


\subsection{Envimnmental Sampline for Radioactivity}

The Pinellas Plant has an extensive environmental sampling program in which samples of air, water, and soil are analyzed for the presence of radionuclides currently and previously used at the plant.

\subsubsection{Air}

During routine operations, small quantities of tritium gas, tritium oxide, and krypton-85 gas are discharged from radiological exhaust stacks. The plant has a network of sampling stations to quantify the amount of tritium that is discharged. Primary sampling stations collect samples directly from the stacks, secondary sampling stations are located around the perimeter of the plant, and tertiary sampling stations are located throughout the county in a circular pattern around the plant (Figures 4-2 and 4-3). Sampling procedures and locations are detailed in the Environmental Monitoring Procedures Manual for Environmental Management [Ref 19].

\section{Amblent Air}

In 1993, seven on-site stations continuously sampled the ambient air for tritium (Figure 4-1). Four on-site stations continue to sample for airborne plutonium even though the last plutonium heat sources were removed from the site in February 1991. There have never been any releases of plutonium at the Pinellas Plant.

Five off-site stations in Pinellas County continuously sample the ambient air for tritium (Figure 4-3). The Clearwater station was rendered inoperable as a result of a storm in March 1993. Arrangements are being made to relocate the station in early 1994. A sixth station at the Manatee County Airport also samples for tritium. Manatee County Airport's measurements represent the normal background level, and are subtracted from the measurements at the other stations. The Pinellas County stations also sample for airborne plutonium. Plutonium isotopes Pu-238 and Pu-239 are analyzed because they were the isotopes in the RTG heat source. The results of the measurements of airborne radionuclides from Pinellas Plant operations are presented in Table 4-3.

The data shows that annual average concentrations of tritium in the ambient air are below detection limits, both at the plant boundary and in the local community and below the DOE DCG limit of $1.0 \mathrm{E}-07 \mu \mathrm{Ci} / \mathrm{ml}$ (3.7E-03 Bq/ml) for tritium in air [Ref. 3]. There were no airborne concentrations of plutonium above the minimum detection limit. 


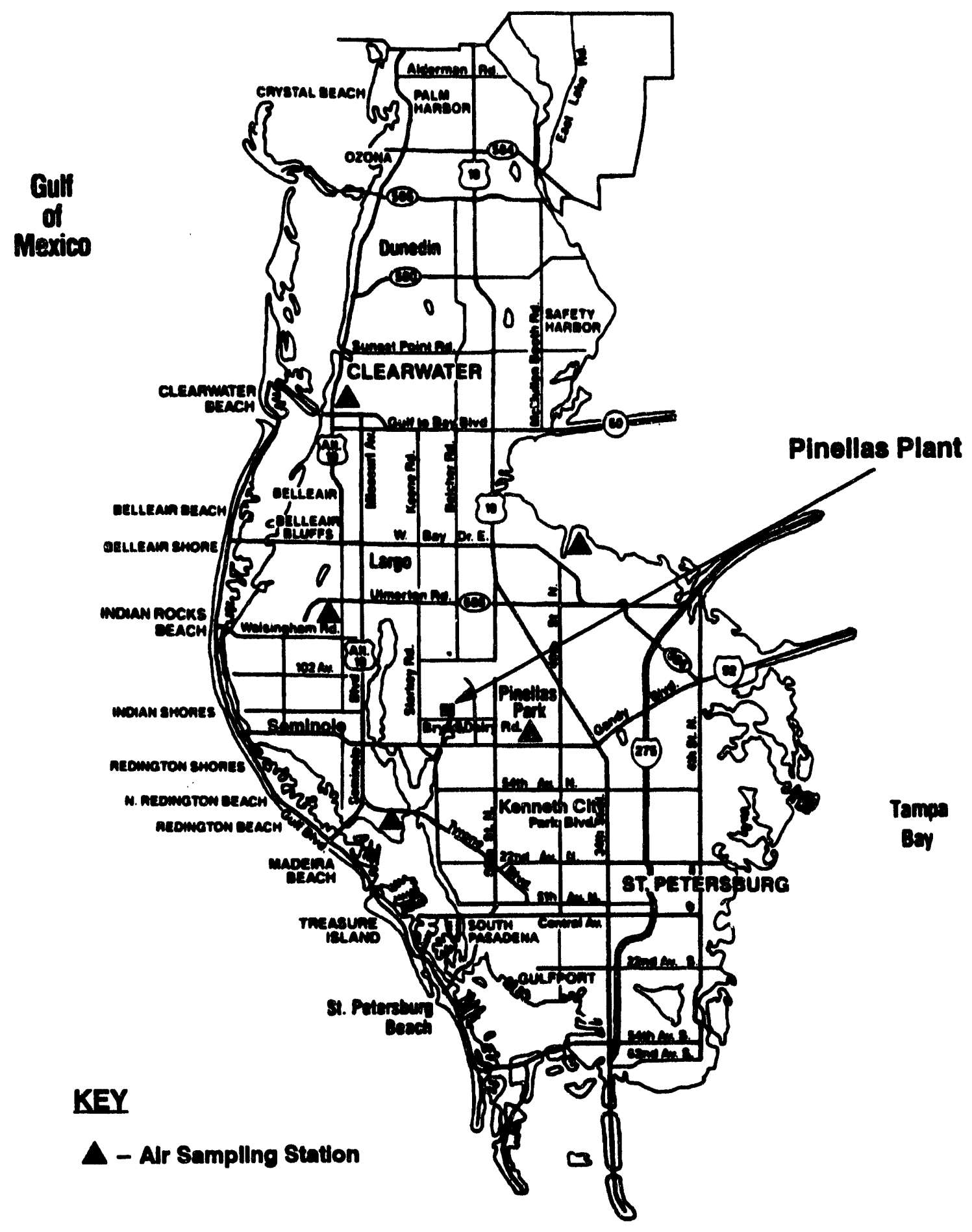

Figure 4-3. Off-Site Air Sampling Station Locations (Note: Manatee Airport Station not shown) 
Table 4-3. 1993 On-Site Ambient Air Sampling Results

\begin{tabular}{|c|c|c|c|c|}
\hline $\begin{array}{l}\text { Station Number } \\
\text { (see Ftgure 4-1) }\end{array}$ & Radlonuclide & $\begin{array}{c}\text { Samples } \\
\text { Frequeney }\end{array}$ & $\begin{array}{l}\text { Anmual } \\
\text { Avernge } \\
\text { Activity, } \\
\text { HCV }\end{array}$ & $\begin{array}{c}\text { Sampling Station } \\
\text { Detection Lumit } \\
\mu \mathrm{CV} / \mathrm{ml}\end{array}$ \\
\hline 1 & Tritium & Monthly & $\overline{B D L}$ & $4.3-12$ to $6.2 \mathrm{E}-12$ \\
\hline 2 & $\begin{array}{l}\text { Tritium } \\
\text { Pu-238 } \\
\text { Pu-239 }\end{array}$ & $\begin{array}{l}\text { Monthly } \\
\text { Biweekly } \\
\text { Biweekly }\end{array}$ & $\overline{\mathrm{BDL}}$ & $\begin{array}{l}3.4 \mathrm{E}-12 \text { to } 6.5 \mathrm{E}-12 \\
2.7 \mathrm{E}-18 \text { to } 1.2 \mathrm{E}-17 \\
4.3 \mathrm{E}-18 \text { to } 1.2 \mathrm{E}-17\end{array}$ \\
\hline 3 & Tritium & Monthly & BDL & $3.8 \mathrm{E}-12$ to $6.5 \mathrm{E}-12$ \\
\hline 4 & $\begin{array}{l}\text { Tritium } \\
\text { Pu-238 } \\
\text { Pu-239 }\end{array}$ & $\begin{array}{l}\text { Monthly } \\
\text { Biweekly } \\
\text { Biweekly }\end{array}$ & $\begin{array}{l}\text { BDL } \\
\text { BDL } \\
\text { BDL }\end{array}$ & $\begin{array}{l}3.3 \mathrm{E}-12 \text { to } 6.2 \mathrm{E}-12 \\
7.2 \mathrm{E}-18 \text { to } 7.9 \mathrm{E}-18 \\
4.2 \mathrm{E}-18 \text { to } 7.5 \mathrm{E}-18\end{array}$ \\
\hline 5 & Trtium & Monthly & $\overline{B D L}$ & $3.3 \mathrm{E}-12$ to $6.2 \mathrm{E}-12$ \\
\hline 6 & $\begin{array}{l}\text { Tritium } \\
\text { Pu-238 } \\
\text { Pu-239 }\end{array}$ & \begin{tabular}{|l} 
Monthly \\
Biweekly \\
Biweekly
\end{tabular} & $\begin{array}{l}\text { BDL } \\
\text { BDL } \\
\text { BDL }\end{array}$ & $\begin{array}{l}3.3 \mathrm{E}-12 \text { to } 6.2 \mathrm{E}-12 \\
3.8 \mathrm{E}-18 \text { to } 1.1 \mathrm{E}-17 \\
1.5 \mathrm{E}-18 \text { to } 6.5 \mathrm{E}-18\end{array}$ \\
\hline 7 & $\begin{array}{l}\text { Tritium } \\
\text { Pu-238 } \\
\text { Pu-239 }\end{array}$ & \begin{tabular}{|l} 
Monthly \\
Biweekly \\
Biweekly
\end{tabular} & $\begin{array}{l}\text { BDL } \\
\text { BDL } \\
\text { BDL }\end{array}$ & $\begin{array}{l}3.4 \mathrm{E}-12 \text { to } 7.1 \mathrm{E}-12 \\
5.7 \mathrm{E}-18 \text { to } 3.2 \mathrm{E}-17 \\
4.6 \mathrm{E}-18 \text { to } 3.0 \mathrm{E}-17\end{array}$ \\
\hline HRS & $\begin{array}{l}\text { Tritium } \\
\text { Pu-238 } \\
\text { Pu-239 }\end{array}$ & \begin{tabular}{|l} 
Monthly \\
BiWeekly \\
Biweekly
\end{tabular} & $\begin{array}{l}<0.52 \mathrm{E}-11 \\
<1.1 \mathrm{E}-18 \\
<1.4 \mathrm{E}-18\end{array}$ & $\begin{array}{l}0.12 \mathrm{E}-11 \text { to } 0.30 \mathrm{E}-11 \\
0.6 \mathrm{E}-18 \text { to } 1.6 \mathrm{E}-18 \\
0.9 \mathrm{E}-18 \text { to } 2.2 \mathrm{E}-18\end{array}$ \\
\hline DOE Standard & $\begin{array}{l}\text { Tritium } \\
\text { Pu-238 } \\
\text { Pu-239 }\end{array}$ & & $\begin{array}{l}1.0 \mathrm{E}-07 \\
3.0 \mathrm{E}-14 \\
2.0 \mathrm{E}-14\end{array}$ & \\
\hline
\end{tabular}

The HRS operates an independent tritium and plutonium air sampling station on-site next to the plant's Station 4 located adjacent to the New Directions in Learning (NDL) Child Development and Partnership School (Figure 4-1). The HRS uses the same sampling equipment, but analyzes the samples in their own laboratory. The HRS data shown in Table 4-4 compares favorably with data reported for Pinellas Plant Station 4. 
Table 4-4. 1993 Off-Site Ambient Air Sampling Results

\begin{tabular}{|c|c|c|c|c|}
\hline Station Name & Radlonnclide & $\begin{array}{l}\text { Sample } \\
\text { Eroguency }\end{array}$ & $\begin{array}{c}\text { Ammual Avernge } \\
\text { Concenturntion, } \\
\mu \mathrm{Cl} / \mathrm{m})\end{array}$ & $\begin{array}{c}D L \\
\mu C V / m i\end{array}$ \\
\hline Civil Defense & $\begin{array}{l}\text { Tritium } \\
\text { Pu-238 } \\
\text { Pu-239 }\end{array}$ & $\begin{array}{l}\text { Monthly } \\
\text { Biweekly } \\
\text { Biweekly }\end{array}$ & $\begin{array}{l}\text { BDL } \\
\text { BDL } \\
\text { BDL }\end{array}$ & $\begin{array}{l}3.3 \mathrm{E}-12 \text { to } 7.5 \mathrm{E}-12 \\
1.3 \mathrm{E}-17 \text { to } 4.4 \mathrm{E}-18 \\
3.3 \mathrm{E}-18 \text { to } 1.3 \mathrm{E}-17\end{array}$ \\
\hline Pinellas Park & $\begin{array}{l}\text { Tritium } \\
\text { Pu-238 } \\
\text { Pu-239 }\end{array}$ & $\begin{array}{l}\text { Monthly } \\
\text { Biweekly } \\
\text { Biweekly }\end{array}$ & $\begin{array}{l}\text { BDL } \\
\text { BDL } \\
\text { BDL }\end{array}$ & $\begin{array}{l}2.9 \mathrm{E}-12 \text { to } 7.0 \mathrm{E}-12 \\
3.3 \mathrm{E}-18 \text { to } 2.5 \mathrm{E}-17 \\
2.1 \mathrm{E}-18 \text { to } 1.6 \mathrm{E}-17\end{array}$ \\
\hline Bay Pines & $\begin{array}{l}\text { Tritium } \\
\text { Pu-238 } \\
\text { Pu-239 }\end{array}$ & $\begin{array}{l}\text { Monthly } \\
\text { Biweekly } \\
\text { Biweekly }\end{array}$ & $\begin{array}{l}\text { BDL } \\
\text { BDL } \\
\text { BDL }\end{array}$ & 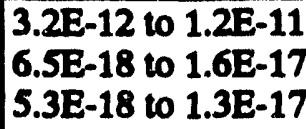 \\
\hline Walsingham & $\begin{array}{l}\text { Tritium } \\
\text { Pu-238 } \\
\text { Pu-239 }\end{array}$ & $\begin{array}{l}\text { Monthly } \\
\text { Biweekly } \\
\text { Biweekly }\end{array}$ & $\begin{array}{l}\text { BDL } \\
\text { BDL } \\
\text { BDL }\end{array}$ & $\begin{array}{l}3.1 \mathrm{E}-12 \text { to } 1.2 \mathrm{E}-11 \\
5.3 \mathrm{E}-18 \text { to } 2.2 \mathrm{E}-17 \\
6.3 \mathrm{E}-18 \text { to } 1.7 \mathrm{E}-17\end{array}$ \\
\hline Clearwater & $\begin{array}{l}\text { Tritium } \\
\text { Pu-238 } \\
\text { Pu-239 }\end{array}$ & $\begin{array}{l}\text { Monthly } \\
\text { Biweekly } \\
\text { Biweekly }\end{array}$ & $\begin{array}{l}\text { BDL } \\
\text { BDL } \\
\text { BDL }\end{array}$ & $\begin{array}{l}3.6 \mathrm{E}-12 \text { to } 6.0 \mathrm{E}-12 \\
1.3 \mathrm{E}-17 \\
6.37 \mathrm{E}-18\end{array}$ \\
\hline
\end{tabular}

\subsubsection{Water}

\section{Surface Water}

With the right meteorological conditions, airborne tritium can be deposited into surface waters. The Pinellas Plant samples both on-site and off-site surface waters regularly and analyzes the samples for tritium to determine the extent of this potential deposition of tritium. The plant samples the South and East on-site stormwater retention ponds and the West on-site stormwater detention pond weekly. The South and East ponds can overflow into the Pinellas County Storm Sewer System. The water entering the storm sewer system combines with run-off from other areas of the county and eventually empties into Boca Ciega Bay. The West Pond outfall was plugged and has not discharged since 1972. The on-site ponds are identified in Figure 4-1.

Twenty-six off-site surface water locations are sampled quarterly and analyzed for tritium. The locations are shown in Figure 4-4. In March 1993, the plant surveyed the surface water locations and revised the location descriptions. Table 4-5 is a summary of on-site surface water sampling data for 1993. The results show very low concentrations of tritium in the on-site ponds, with most samples at or below the detection limit. 


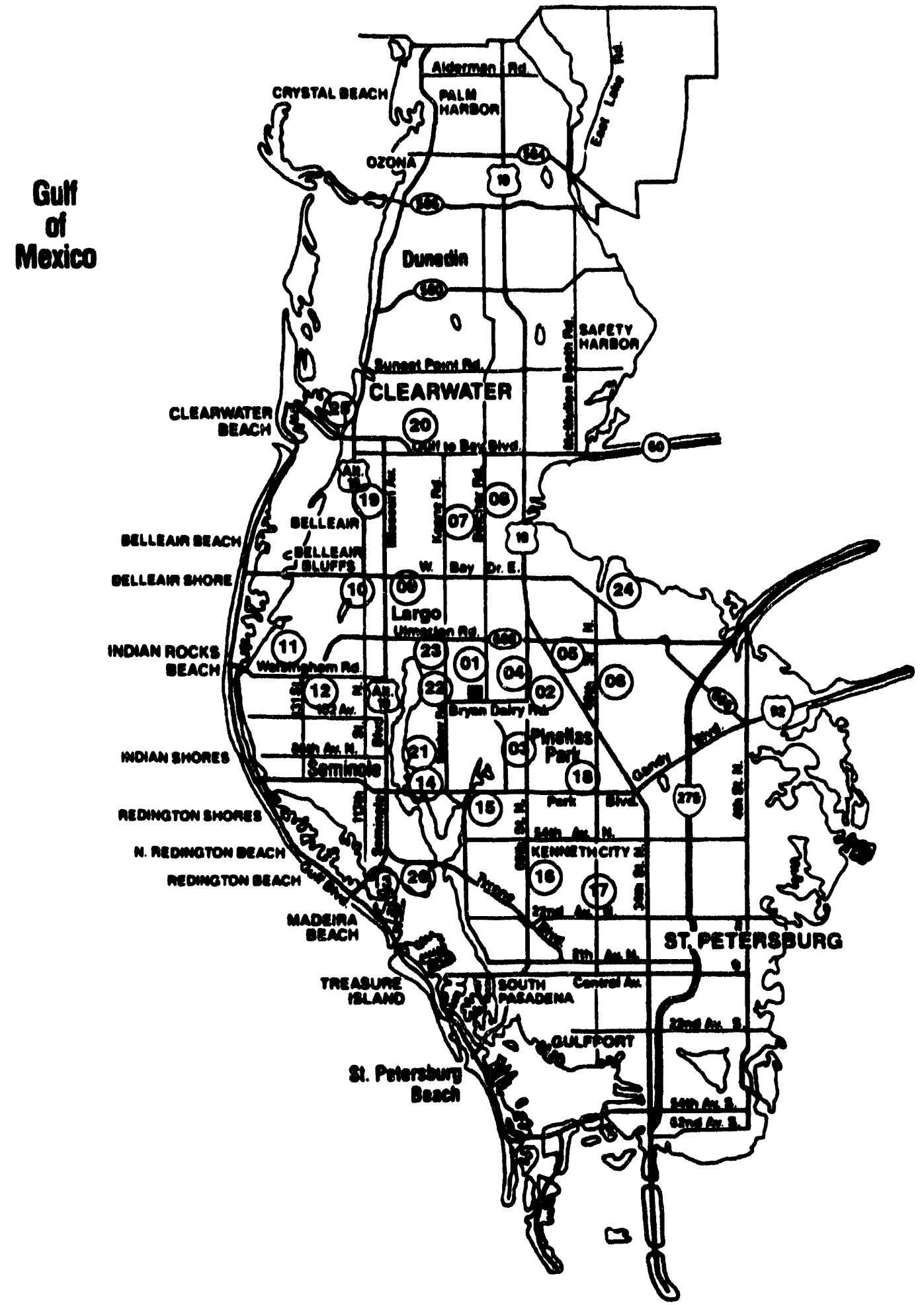

Figure 4-4. Off-Site Surface Water Sampling Locations 
Measurements of tritium in all off-site surface water samples for 1993 were below the detection limit, which ranged between 0.32 and $0.48 \mathrm{pCi} / \mathrm{ml}$. In all samples analyzed, the concentrations were orders of magnitude below the DOE DCG standard for drinking water of 2.0E $+03 \mathrm{pCi} / \mathrm{ml}(74 \mathrm{~Bq} / \mathrm{ml})$ and EPA drinking water standard of $20 \mathrm{pCi} / \mathrm{ml}(0.74 \mathrm{Bg} / \mathrm{ml})$.

The HRS established a surface water sampling and analysis program at the plant. The HRS samples and analyzes the on-site ponds and various off-site surface waters surrounding the plant for tritium. The on-site pond tritium concentrations detected by the HRS, reported in Table 4-5, compare very closely with data collected and analyzed by the plant. The HRS and the plant sample off-site surface waters in different locations; therefore, the results are not directly comparable.

Table 4-5. On-Site Surface Water Tritium Concentrations

\begin{tabular}{|c|c|c|}
\hline On-site Location & $\begin{array}{c}\text { Annual Average } \\
\text { Concentration, } \\
\text { pCV/mil }\end{array}$ & $\begin{array}{l}\text { Detection Lmit } \\
\text { Range, pCV/mi }\end{array}$ \\
\hline Pinellas Plant & & \\
\hline East Pond & BDL & 0.32 to 0.48 \\
\hline West Pond & BDL & 0.32 to 0.48 \\
\hline South Pond & BDL & 0.32 to 0.48 \\
\hline HRS Samples & & \\
\hline East Pond & BDL & 0.13 to 0.14 \\
\hline West Pond & BDL & 0.13 to 0.14 \\
\hline South Pond & BDL & 0.13 to 0.14 \\
\hline
\end{tabular}

\section{Groundwater}

Tritium has been detected in the Pinellas Plant groundwater. During 1993, the plant analyzed 249 samples for tritium from monitoring wells in the surficial and Floridan aquifers as part of the Pinellas Plant Groundwater Monitoring Program. The highest concentration of tritium detected in samples from the surficial aquifer was $3.68 \mathrm{pCi} / \mathrm{ml}$ which is significantly below the SDWA MCL of $20 \mathrm{pCi} / \mathrm{ml}$. Most surficial aquifer samples were reported to be lower than the minimum detection limit. Analysis of samples from the Floridan aquifer revealed no detectable levels of tritium. The plant will continue to analyze groundwater from selected wells in both aquifers for tritium on a quarterly basis. 


\subsubsection{Soll}

Soil from four on-site and four off-site locations were collected in 1993 and analyzed for plutonium even though the last plutonium heat sources were removed from the site in February 1991. Soil samples are selected annually from a master list of sites as shown in Table 4-6. The on- and off-site soil sampling locations are shown in Figures 4-5 and 4-6. All of the soil samples analyzed in 1993 had Pu-238 levels below the detection limit which was $0.0028 \mathrm{pCi} / \mathrm{g}$.

Table 4-6. Soil Sample Location Schedule

\begin{tabular}{|l|l|l|}
\hline Year & On-Site Locations & Or-Site Locntions \\
\hline 1987 & GE-05 GE-11 & PC-03 PC-05 PC-07 PC-16 \\
\hline 1988 & GE-04 GE-08 & PC-02 PC-06 PC-13 PC-14 \\
\hline 1989 & GE-03 GE-09 & PC-04 PC-09 PC-11 PC-15 \\
\hline 1990 & GE-10 GE-14 & PC-01 PC-08 PC-10 PC-12 \\
\hline 1991 & GE-12 GE-13 & PC-03 PC-05 PC-07 PC-16 \\
\hline 1992 & GE-01 GE-06 & PC-02 PC-06 PC-13 PC-14 \\
\hline 1993 & GE-02 GE-07 HRS-01 HRS-02 & PC-04 PC-09 PC-11 PC-15 \\
\hline 1994 & GE-05 GE-11 & PC-01 PC-08 PC-10 PC-12 \\
\hline 1995 & GE-04 GE-08 & PC-03 PC-05 PC-07 PC-16 \\
\hline 1996 & GE-03 GE-09 & PC-02 PC-06 PC-13 PC-14 \\
\hline 1997 & GE-10 GE-14 & PC-04 PC-09 PC-11 PC-15 \\
\hline
\end{tabular}

The plant observed Pu-239, from above ground testing of nuclear weapons, above the detection limit in six soil samples collected in 1993. Pinellas Plant RTG plutonium was composed of approximately $80 \%$ $\mathrm{Pu}-238$ and $16 \% \mathrm{Pu}-239$, and would be found in that ratio if dispersed into the environment. Plant personnel have never observed any Pu-238 in environmental samples. 


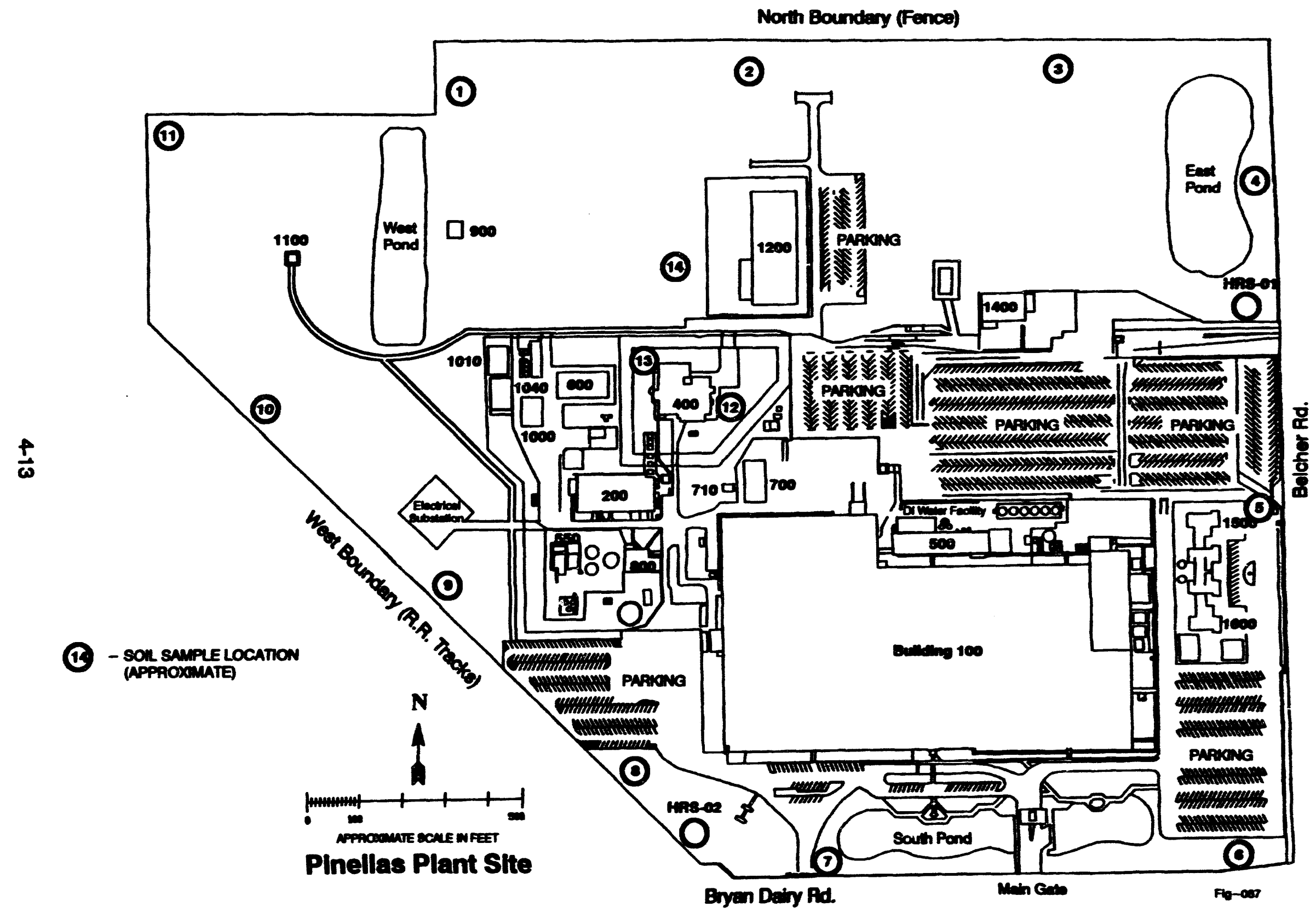

Figure 4-5. On-Site Soil Sampling Locations 


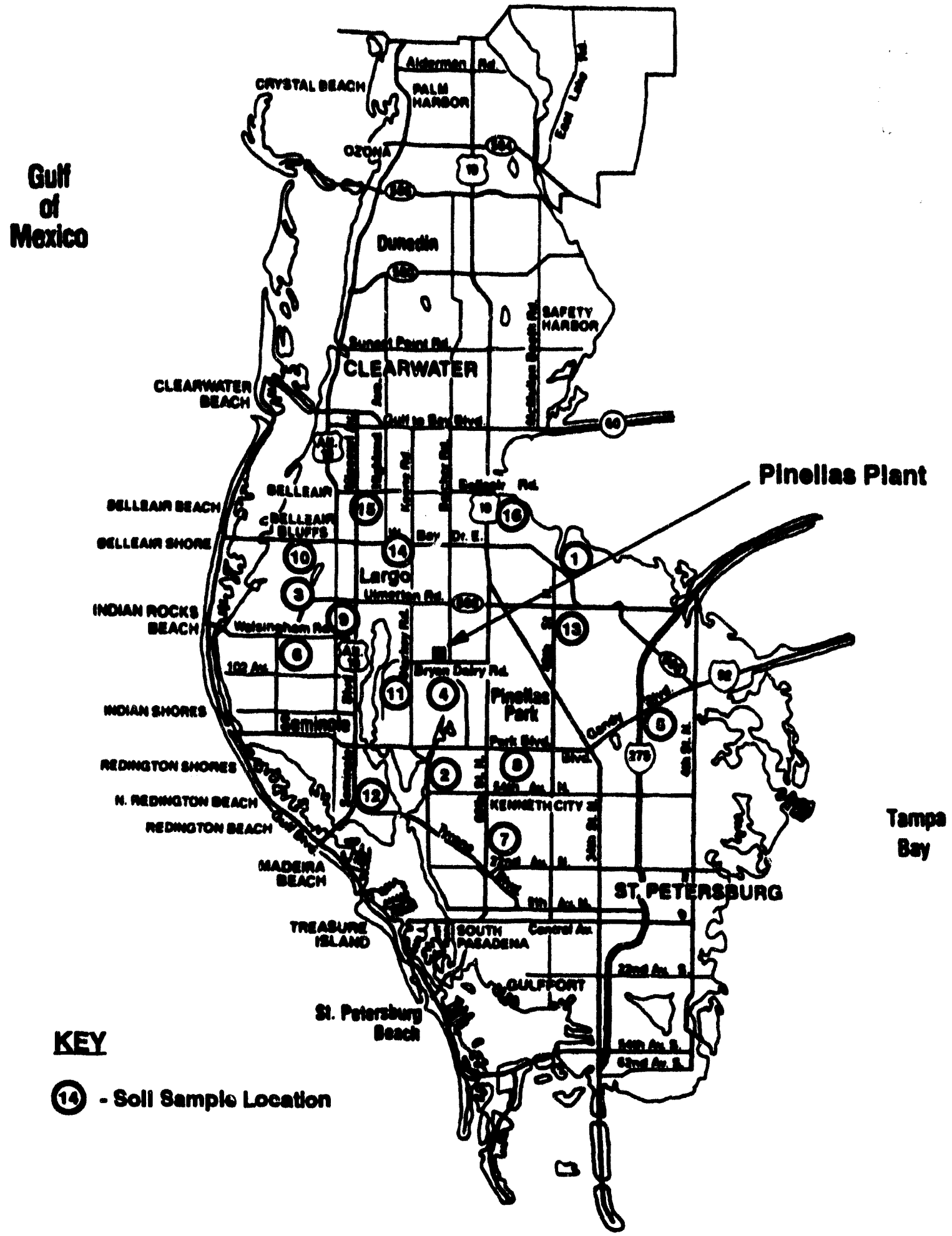

Figure 4-6. Off-Site Soil Sampling Locations 


\subsection{Exoluntlon of Potential Dare to the Publls}

\subsubsection{Dose Standards}

Pinelles Plant requirements for radiation protection of the public and the environment are promulgated by DOE 5400.5 [Ref. 3]. These requirements set a cumulative public dose limit for all DOE sources of radiation for all exposure modes at $100 \mathrm{mrem} / \mathrm{yr}(1.0 \mathrm{mSv})$ effective dose equivalent. The order also incorporates the EPA $10 \mathrm{mrem} / \mathrm{yr}(0.1 \mathrm{mSv})$ limits for atmospheric pathways [Ref. 8] which applies to the Pinellas Plant. The exposure limit for drinking water for all DOE sources of radionuclides is $4 \mathrm{mrem} / \mathrm{yr}$ (0.04 mSv) [Ref. 20].

DOE 5400.5 presents a DCG for each radionuclide. DCG values are listed as reference values for each of three modes of exposure to the radionuclide: inhalation, absorption, and ingestion DCG levels are values that equate to the $100 \mathrm{mrem} / \mathrm{yr}(1.0 \mathrm{mSv})$ dose limits listed in DOE 5400.5.

The EPA standard [Ref. 8] requires continuous monitoring of sources having a potential to discharge radionuclides into the air in quantities that cause an effective dose equivalent in excess of $1 \%$ of the standard, or $0.1 \mathrm{mrem} / \mathrm{yr}$. The plant uses two computer codes to verify compliance with radionuclide emission standards. The COMPLY code is used to verify that potential worst-case plant emissions are below 1\% of the $10 \mathrm{mrem} / \mathrm{yr}$ EPA standard. The CAP88-PC code is used to verify that actual annual emissions do not result in a dose to the public greater than the 10 mrem/yr standard. CAP88-PC was used for the 1993 Radionuclide Air Emissions Annual Report scheduled for submittal to EPA in June 1994.

\subsubsection{Dose to the Public Due to Naturally Occurring Radiation}

Independent of any DOE sources of radiation, the population receives an annual radiation dose from five natural sources [Ref. 21]:

\section{Cosmlc Radiation from Outer Space}

Cosmic rays are extremely penetrating. The dose varies with altitude. The average annual dose equivalent to people in the United States is 28 mrem (0.28 mSv).

\section{External Gamma Radiation}

Naturally occurring radionuclides produce external gamma exposures. The major contributors are radon and its isotopes, which arise from the natural decay of uranium and thorium deposited in rocks, and 
potassium-40. Average annual dose varies from $16 \mathrm{mrem}(0.16 \mathrm{mSv})$ at the Atlantic Coast to $63 \mathrm{mrem}(0.6 \mathrm{~m} \mathrm{mSv})$ at the eastern slopes of the Rocky Mountains.

\section{Internal Radiation}

The primary contributors to the internal radiation dose are potassium-40, polonium-210, radium-226, and carton-14, which are ingested in foodstufts, and radon-222 and its daughters, which are inhaled. These natural radionuclides contribute an average annual dose of $200 \mathrm{mrem}$ (2.0 mSv).

\section{Consumer Products}

Radiation occurs incidentally to the product function of consumer goods, such as television receivers, and provides an annual average dose of 6 to 12 mrem ( 0.6 to $0.12 \mathrm{mSv}$ ) to the average member of the public.

\section{Medical Diagnosis and Therapy}

The average annual dose equivalent to all individuals from all medical examinations is $53 \mathrm{mrem}(0.53 \mathrm{mSv})$.

The total dose from these sources of naturally occurring radiation is approximately $360 \mathrm{mrem}$ ( $3.6 \mathrm{mSv}$ ) per year. When compared to this dose the average dose to a member of the population within a 50-mile radius resulting from plant operations is extremely small, $0.000017 \mathrm{mrem} / \mathrm{yr}$.

\subsubsection{Potential Dose to the Population Within 50 Miles of the Plant Site}

Pinellas Plant personnel used the EPA-approved CAP88-PC code, with actual 1993 total emissions of tritium and krypton-85, to determine the radiation dose to all individuals residing within $\mathbf{5 0}$ miles of the plant site. This dose is expressed in person-rem. For example, if 1,000 people resided in the area and each received a radiation dose of $1 \mathrm{rem}$, the population dose would be 1000 person-rem. Based on the 1990 census, the population within 50 miles of the plant is estimated to be 2,529,870. The calculated radiation exposure to the average member of the population is $1.7 \mathrm{E}-05 \mathrm{mrem} / \mathrm{yr}$ or $4.3 \mathrm{E}-02(0.043)$ person-rem/yr for the population. The 1993 population exposure is lower than the preceding two years: 1991, 9.1E-01 (0.91) person-rem; 1992, 1.9E-01 (0.19) person-rem. This is due to lower tritium emissions at the plant.

\subsubsection{Potential Dose to the Most Exposed Member of the Publlc}

The potential dose to the most exposed individual of the public was also determined using the CAP83-PC computer code and actual 1993 emissions of tritium and krypton-85. The computer code assumes that the 
member of the public remains at the residential location closest to the plant continuously throughout the year and ingests foodstuffs that are locally grown. These are very conservative assumptions since Pinellas County is very urban and most foodstuffs are imported from outside the county. The results of the modeling for three nearby locations are presented in Table 4-7, and show that plant emissions result in estimated dose to the public well below EPA and DOE dose limits.

Table 4-7. 1993 CAP88-PC Dose Calculations

\begin{tabular}{|c|c|c|c|}
\hline Deacription & Locition & $\begin{array}{l}\text { Eloctive Dose } \\
\text { Equivalent; mrem/yr } \\
\text { (mSv/yr) }\end{array}$ & $\begin{array}{l}\text { DPA ind } \\
\text { DOE } \\
\text { Dose } \\
\text { Limits } \\
\text { (miremlyn) }\end{array}$ \\
\hline Apartment Bldg. & 620 meters WSW of site & 1.9E-03 (1.9E-05) & 10.0 \\
\hline Apartment Bldg. & 730 meters NNE of site & $1.6 \mathrm{E}-03(1.6 \mathrm{E}-05)$ & 10.0 \\
\hline House with pool & 1,040 meters $N W$ of site & 1.7E-03 (1.7E-05) & 10.0 \\
\hline NDL School & 130 meters $\mathrm{E}$ of site & $1.5 \mathrm{E}-03(1.5 \mathrm{E}-05)$ & 10.0 \\
\hline $\begin{array}{l}\text { Most Exposed } \\
\text { Individual }\end{array}$ & 480 meters $W$ of site & 2.3E-03 (2.3E-05) & 10.0 \\
\hline
\end{tabular}

As determined by the model, the location of the most exposed individual (MEI) is $\mathbf{4 8 0}$ meters west of the Building $\mathbf{1 0 0}$ Main Stack; however, there are no full-time residents at this location. The doses listed in the table include all radionuclides and all pathways.

\subsubsection{Potential Dose Due to Plutonium}

Ongoing monitoring results continue to show no plutonium from RTG operations was released to the environment so there is no radiation dose to the public. Because no plutonium was ever released to the environment, plutonium dose pathway is not considered in the CAP88-PC dose assessment model.

\subsubsection{Minor Source Compliance}

The EPA requires continuous monitoring of sources having a potential to discharge radionuclides into the air in quantities that cause an effective dose equivalent greater than $1 \%(0.1 \mathrm{mrem} / \mathrm{yr})$ of the $10 \mathrm{mrem} / \mathrm{yr}$ standard. The plant used the COMPLY computer code to calculate the dose to the most exposed member of the public under a set of worst-case assumptions, rather than the actual emissions data. In the worst-case, emissions controls, including the tritium recovery system, are not 
functioning, and all of the tritium and $\mathrm{Kr}-85$ used during the year, 1700 curies and 100 curies, respectively is discharged. The results of this calculation show that even under these circumstances the most exposed member of the public would receive a dose of 9.6E-02 (0.096) mrem for the year, an amount under $1 \%$ of the standard. The plant is therefore not required to monitor continuously for tritium. As a best management practice; however, the plant continuously monitors the tritium and Kr-85 emissions and the flowrate of the four radiological exhaust stacks as described in this, and previous, sections of this report.

\subsection{Unplanned Releases and Envimonmental Occurrences}

On April 20, 1993, because of an equipment malfunction, the plant released 9.3 curies of $\mathrm{Kr}-85$ to the atmosphere through the Building 100 Main Stack at approximately 9:30 a.m. The release quantity, determined by mass balance calculations, was well below the HRS reportable quantity of 30 curies for $\mathbf{K r}-85$ in a 24-hour period. At the time of the release, the wind, as indicated by the on-site meteorological tower, was blowing toward the northwest at 5.7 meters/sec. The maximum dose to an individual at the nearest residence northwest of the plant was determined by the HOTSPOT computer model to be 3.2E-05 mrem. This dose, in addition to the typical dose from routine annual releases from the plant, is below $0.1 \%$ of the DOE and EPA standard of $10 \mathrm{mrem} / \mathrm{yr}$. The Radiological Safety Analysis Computer Program (RSAC-4) calculated the dose independently for verification. The independent result was a predicted external effective dose equivalent of $8.9 \mathrm{E}-05 \mathrm{mrem}$ at the nearest residence. This value of the same order of magnitude as that calculated by HOTSPOT, and is approximately 100,000 times lower than the DOE/EPA standard.

On October 6, 1993, Health Physics personnel discovered that power to the main radiological exhaust stack sampling pumps and Kanne Chamber Monitor had been inadvertently shut off for seven and one-half hours during a maintenance operation. Plant personnel immediately restored power to the pumps. Airflow of the main stack was not affected, and all air monitors in the tritium processing areas functioned normally. Only normal, low levels of tritium operations were conducted that day. Corrective action included providing separate power disconnects and posting a sign to warn personnel that Health Physics notification and approval are required before disconnecting power to the sampling system and Kanne Chamber Monitor.

On November 2, 1993, Health Physics personnel discovered that the pumps providing air flow to the laboratory radiological exhaust stack Kanne Chamber Monitor were not operating. Maintenance personnel identified a loose electrical connection in the motor control circuit as the cause. Maintenance personnel immediately reconnected the wire and restored power to the pumps. During this period, only routine releases of tritium occurred. The equipment failure did not 
affect stack sampling system operation. Corrective action included developing a procedure to check for loose electrical connections and tighten, if necessary, during routine preventive maintenance on the pumps.

\subsection{ALARA Program}

The Pinellas Plant maintains an active ALARA program for environmental releases of radioactive material that sets emission goals significantly lower than the amounts permitted by regulations. In 1993, the plant remained below all ALARA goals for tritium releases, and tritium releases from the plant through the stacks and to the sewer system were far below the amounts permitted. Because of some equipment difficulties, releases of $\mathrm{Kr}-85$ exceeded the original ALARA goal of 15 curies, by 4 curies.

ALARA goals for CY1994 include:

a) Minimizing releases of $\mathrm{Kr}-85$ to less than $\mathbf{4 0}$ curies.

b) Limiting tritium releases to less than $\mathbf{7 5}$ curies.

c) Limiting tritium releases to the POTW to less than 2 curies. 
This page left blank intentionally. 


\subsection{ENVIRONMENTAL NONRADIOLOGICAL PROGRAM INFORMATION}

\subsection{Atmospheric Nonradiological Emissions}

The Pinellas Plant nonradiological air emissions are regulated under the Air Emissions Permit, AC52-206678 [Ref. 10]. The majority of emissions from the Pinellas Plant are from VOC/OC resulting from parts cleaning activities at the plant. Total emissions of $\mathrm{VOC} / \mathrm{OC}$ are restricted to 41.1 tons per year. Total VOC/OC emissions for CY1993 were approximately 22.4 tons, well below permit levels. Table 5-1 provides the actual emissions levels for CY1993. Figure 5-1 shows the actual compound usage for CY1993.

Table 5-1. 1993 Actual Emissions

\begin{tabular}{|l|l|}
\hline \multicolumn{1}{|c|}{ Compound } & \multicolumn{1}{c|}{ Amount } \\
\hline Amyl Acetate & 1,052 \\
\hline Ethanol & 11,013 \\
\hline Acetone & 2,270 \\
\hline Methylene Chloride & 6,258 \\
\hline Trichloroethane & 8,416 \\
\hline Trichloroethylene & 7,750 \\
\hline Trichlorofluoromethane & 1,705 \\
\hline Trichlorotrifluoroethane & 2,177 \\
\hline Other VOCs & 4,089 \\
\hline Total - lbs & 44,728 \\
\hline Total - tons & 22 \\
\hline
\end{tabular}




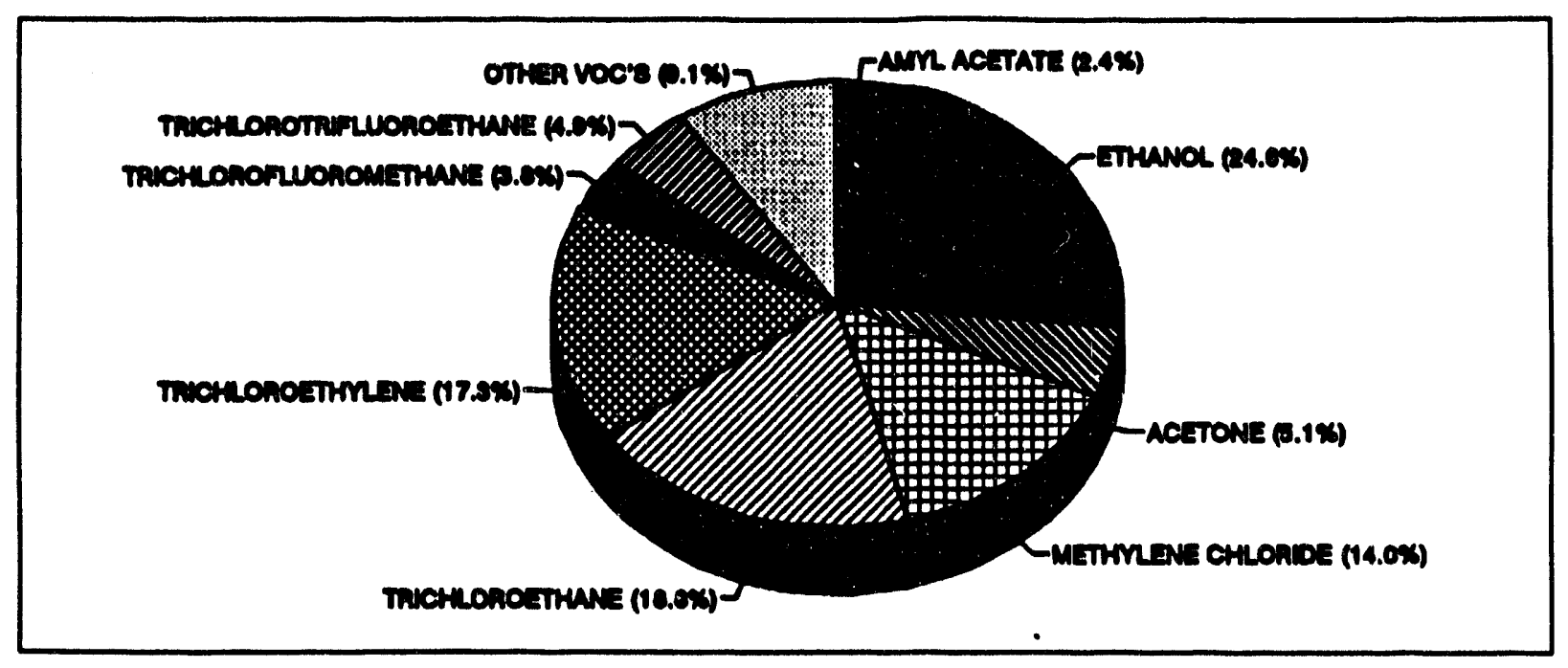

Figure 5-1. Pinellas Plant Actual 1993 VOC/OC Emissions

\subsection{Water}

\subsubsection{Wastewater}

Wastewater consisting of sanitary sewage and pH-neutralized industrial wastewater discharged from the IWNF to the PCSS is continuously sampled and analyzed for the parameters specified in the plant's Industrial Wastewater Discharge Permit, 018-IE [Ref. 11]. The samples for metals, BOD, and TSS are collected by PCSS-approved automatic samplers located in Building 550 at the IWNF (Figure 5-2). Samples for cyanide and TTO are grab samples collected directly from the industrial and combined wastestreams at the IWNF. The sample bottles are identified on the Chain-of-Custody document and delivered to the appropriate in-house laboratory for analysis. The QA program for these samples is described in Section 7.

The plant reviews analytical results immediately to determine if they are within applicable control limits and are below the permit limits. The Pinellas Plant maintains trend charts to indicate when permit limits are being approached. The plant proactively implements corrective actions to prevent exceeding permit limits. Any value exceeding permit limits is reported to DOE and to the Industrial Program Manager of PCSS.

The Pinellas Plant reports routine monitoring results monthly to DOE and the PCSS Industric!? Program Manager. Table 5-2 summarizes the analyses performed on the combined wastestream discharged from the site in 1993. 
North Boundary (Fence)

$\dddot{\omega}$

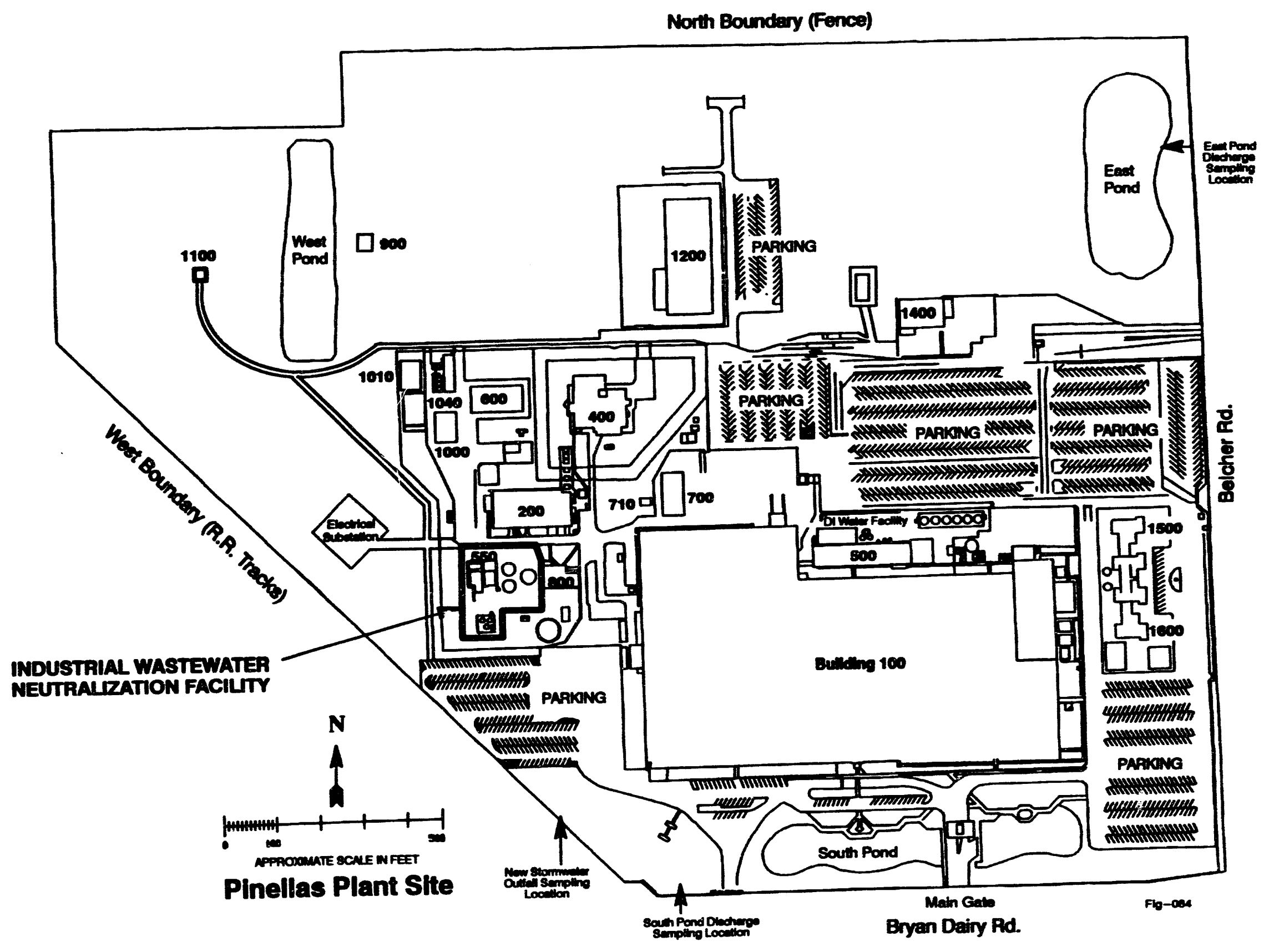

Figure 5-2. Nonradiological Liquid Effluent Sampling Locations 
Table 5-2. Combined Nonradiological Liquid Effluent Analysis Results

\begin{tabular}{|c|c|c|c|c|c|}
\hline \multirow[b]{2}{*}{ Parnmetar } & \multirow[b]{2}{*}{$\begin{array}{l}\text { Sampling } \\
\text { Frequency }\end{array}$} & \multicolumn{4}{|c|}{ Concentration, mg/h } \\
\hline & & $\begin{array}{l}\text { Permilt } \\
\text { Unitio }\end{array}$ & Range & Avernge & $\begin{array}{l}\text { Defection } \\
\text { Limit }\end{array}$ \\
\hline Cadmium & Weekly & 0.2 & $<0.01$ & $<0.01$ & 0.01 \\
\hline Chromium & Weekdy & 2.6 & $<0.02$ & $<0.02$ & 0.02 \\
\hline Copper & Weekly & 1.0 & $0.65-0.11$ & 0.38 & 0.01 \\
\hline Cyanide & Monthly & 1.0 & $<0.1$ & $<0.1$ & 0.1 \\
\hline Lead & Weekly & $\overline{0.6}$ & $<0.05$ & $<0.05$ & 0.05 \\
\hline Mercury & Weekly & 0.1 & $0.00006-0.00016$ & 0.00011 & 0.00005 \\
\hline Nickel & Weekly & 1.0 & $<0.05$ & $<0.05$ & 0.05 \\
\hline Silver & Weekly & 0.4 & $<0.01$ & $<0.01$ & 0.01 \\
\hline Zinc & Weekly & 1.0 & $0.09-0.02$ & 0.06 & 0.01 \\
\hline BOD & Monthly & 250.0 & $66.5-15$ & 32.2 & 1.0 \\
\hline TSS & Monthly & 250.0 & $54.6-30.3$ & 52.9 & 1.0 \\
\hline TTO & Semiannually & 0.85 & $0.02-0.0054$ & 0.0127 & 0.001 \\
\hline pH & Continuous & $5.5-9.5$ & $5.5-8.5$ & N/A & 0.1 \\
\hline $\begin{array}{l}\text { Industri } \\
\text { 91-26. } \\
\text { BOD = } \\
\text { TTO = }\end{array}$ & Wastewater D & harge $\mathrm{Pe}$ & $\begin{array}{l}\text { ait } 1018-\mathbb{E} \text { and Pi } \\
\text { TSS = Total Sus } \\
\text { Not Applicable }\end{array}$ & $\begin{array}{l}\text { ellas Coun } \\
\text { ended Sol }\end{array}$ & Ordinance \\
\hline
\end{tabular}

All concentrations are in $\mathrm{mg} / \mathrm{l}$ except $\mathrm{pH}$, which is measured in $\mathrm{pH}$ units. Compared with the 1992 data, the copper levels are slightly higher and zinc has approximately the same average, but a lower maximum. The BOD has a wider range, but approximately the same average as last year. The most significant change is the TTO, which is three times lower than last year's figures. There were no instances in which the plant exceeded permitted levels in 1993.

The PCSS maintains a secured sampling station on the Pinellas Plant site. Samples of the plant's combined effluent from this station are collected on an irregular, unannounced basis and analyzed by the county to verify compliance with the permit. After samples are collected, the plant obtains split samples from county personnel to compare results. Samples were collected and analyzed by the county on six occasions in 1993, with the results shown in Table 5-3. In all cases, the amounts measured independently and were below the permitted levels. 
Table 5-3. PCSS and Pinellas Plant Wastewater Split Sample Comparison

\begin{tabular}{|c|c|c|c|c|c|c|c|c|c|c|c|c|c|}
\hline \multirow{3}{*}{$\begin{array}{l}\text { Sample } \\
\text { Date } \\
\text { Parameter }\end{array}$} & \multicolumn{13}{|c|}{ Concentration, $m \boldsymbol{A}$} \\
\hline & \multicolumn{2}{|c|}{ March 16, 1993} & \multicolumn{2}{|c|}{ March 17, 1993} & \multicolumn{2}{|c|}{ June 22, 1993} & \multicolumn{2}{|c|}{ September 9, 1993} & \multicolumn{2}{|c|}{ September 10, 1993} & \multicolumn{2}{|c|}{ Decentber 1, 19s3 } & \multirow[b]{2}{*}{$\begin{array}{l}\text { Permit } \\
\text { Limits* }\end{array}$} \\
\hline & $\begin{array}{l}\text { PCSS } \\
\text { Result }\end{array}$ & $\begin{array}{l}\text { Plant } \\
\text { Result }\end{array}$ & $\begin{array}{l}\text { PCSS } \\
\text { Result }\end{array}$ & $\begin{array}{l}\text { Plant } \\
\text { Result }\end{array}$ & $\begin{array}{l}\text { PCSS } \\
\text { Result }\end{array}$ & $\begin{array}{l}\text { Plant } \\
\text { Result }\end{array}$ & $\begin{array}{l}\text { PCSS } \\
\text { Result }\end{array}$ & $\begin{array}{l}\text { Plant } \\
\text { Result }\end{array}$ & $\begin{array}{l}\text { PCSS } \\
\text { Result }\end{array}$ & $\begin{array}{l}\text { Plant } \\
\text { Result }\end{array}$ & $\begin{array}{l}\text { PCSS } \\
\text { Resunt }\end{array}$ & $\begin{array}{l}\text { Plant } \\
\text { Result }\end{array}$ & \\
\hline Cadmium & $<0.01$ & $<0.01$ & $<0.01$ & $<0.01$ & $<0.01$ & $<0.01$ & $<0.01$ & $<0.01$ & $<0.01$ & $<0.01$ & $\leq 0.01$ & $<0.01$ & 0.2 \\
\hline Chromium & $<0.05$ & $<0.02$ & $<0.05$ & $<0.02$ & $<0.05$ & $<0.02$ & $<0.05$ & $<0.02$ & $<0.05$ & $<0.02$ & $<0.05$ & $<0.02$ & 2.6 \\
\hline Copper & 0.139 & 0.44 & 0.254 & 0.24 & 0.270 & 0.29 & 0.228 & 0.27 & 0.250 & 0.26 & 0.125 & 0.13 & 1.0 \\
\hline Lead & $<0.20$ & $<0.05$ & $<0.20$ & $<0.05$ & $<0.20$ & $<0.05$ & $<0.20$ & $<0.05$ & $<0.20$ & $<0.05$ & $<0.20$ & $<0.05$ & 0.6 \\
\hline Nickel & $<0.05$ & $<0.05$ & $<0.05$ & $<0.05$ & $<0.05$ & $<0.05$ & $<0.05$ & $<0.05$ & $<0.05$ & $<0.05$ & $<0.05$ & $<0.05$ & 1.0 \\
\hline Silver & $<0.02$ & $<0.01$ & $<0.02$ & $<0.01$ & $<0.02$ & $<0.01$ & $<0.02$ & $<0.01$ & $<0.02$ & $<0.01$ & $<0.02$ & $<0.01$ & 0.4 \\
\hline Zinc & 0.079 & 0.09 & 0.104 & 0.09 & 0.047 & 0.05 & 0.085 & 0.09 & 0.117 & 0.07 & 0.079 & 0.03 & 1.0 \\
\hline pH (mean) & 7.84 & 7.35 & 7.96 & 7.3 & 7.84 & 7.7 & 7.58 & 7.25 & 8.14 & 7.8 & 7.76 & 7.8 & $5.5-9.5$ \\
\hline Cyanide & $\mathbf{N} / \mathbf{A}$ & $\mathbf{N} / \mathbf{A}$ & N/A & N/A & N/A & N/A & N/A & N/A & N/A & $\mathbf{N} / \mathbf{A}$ & $<0.005$ & $\mathbf{N} / \mathbf{A}$ & 1.0 \\
\hline BOD & N/A & N/A & N/A & N/A & N/A & N/A & 48 & N/A & 65 & N/A & N/A & N/A & 250 \\
\hline TSS & N/A & N/A & N/A & N/A & N/A & N/A & 103 & N/A & 112 & N/A & $\mathbf{N} / \mathbf{A}$ & N/A & 250 \\
\hline \multicolumn{14}{|c|}{$\begin{array}{l}\text { Industral Wastewater Discharge Permit \#018-IE and Pinellas County Ordinance 91-26. } \\
\text { N/A = Not Analyzed } \\
\text { All units in milligrams per litcr (mg/) except pH. }\end{array}$} \\
\hline
\end{tabular}




\subsubsection{Surface Water}

In 1993, the plant sampled the three on-site ponds quarterly for VOCs and metals. Laboratory analytical results for VOCs were below the analytical detection limit with the exception of some results for the East Stormwater Retention Pond. Two sample results from the pond indicated trace levels of 1,2-Dichloroethylene and methylene chloride. No regulatory standard exists for methylene chloride and the other result is well below the standard. The only metal parameters detected above standards were iron and manganese. These slightly exceeded the standard in only one sampling period and were attributed to natural environmental conditions. All other metal parameters remained below the detection level.

\subsubsection{Stormwater}

The Pinellas Plant sampled and analyzed stormwater discharge from two outfalls and submitted an individual permit application for stormwater discharges associated with industrial activity in September 1992. In 1993, the plant discovered an additional existing outfall as a result of the dye-tracer study of the storm drain system. The discharge from this outfall was sampled and analyzed during two storm events in 1993 and the original permit application was revised and submitted to EPA. The plant has not yet received a NPDES stormwater discharge permit from the EPA.

\subsection{Environmental Occurrences}

The Pinellas Plant had no environmental releases that resulted in the violation of any permit limits during 1993. There was, however, one occurrence that resulted in regulatory agency notification for informational purposes.

On July 6, 1993, the plant discovered a small depression in the ground outside the southwest corner of Building 100, Main Building, caused by a leak in the chemical drain system. The plant immediately notified the PCSS Industrial Program Director of the occurrence. Plant personnel sampled the soil and groundwater around the leak, while a method was devised to repair it. The analysis of the samples revealed the presence of low concentration of chromium, lead, copper, silver, nickel and zinc. During the leak repair, groundwater from de-watering operations was discharged to the POTW. After repair, final soil and groundwater samples did not identify any contaminants above regulatory limits, and the soil was returned to the hole to cover the drain piping. The plant again notified the PCSS Industrial Program Director when repairs were completed.

\subsection{SARA Title III Reporting}

The Pinellas Plant reports annual Toxic Chemical inventories and release quantities as required by Sections 312 and 313 of the SARA of 1986, Title III. These reports disclose plant chemical inventories, usage rates and emission 
quantities and are provided to local and State emergency planning committees and local fire authorities. Additionally, MSDSs are submitted to the local Emergency Planning Committee, State Emergency Response Commission, and local fire departments in accordance with Section 311 of SARA. Table 5-4 summaries the CY1993 SARA 312 report, submitted March 1, 1994.

Table 5-4. Report of Pinellas Plant's Compounds for Calendar Year 1993

\begin{tabular}{|c|c|c|c|c|}
\hline \multirow[b]{2}{*}{ Chemial } & \multirow[b]{2}{*}{$\begin{array}{c}\text { Days } \\
\text { On-Site }\end{array}$} & \multicolumn{3}{|c|}{ Dally Inventory, Bbe. } \\
\hline & & Moximum & Average & $\begin{array}{c}\text { EPA } \\
\text { Dacignation }\end{array}$ \\
\hline Acetic Acid & 365 & 13,861 & 13,840 & HS \\
\hline Acetone & 365 & 10,774 & 10,214 & HS \\
\hline Aluminum Oxide & 365 & 10,490 & 7,502 & HS \\
\hline Ammonia & 365 & 1,057 & 1,057 & EHS \\
\hline Argon & 365 & 133,400 & 104,844 & HS \\
\hline Ethyl Alcohol & 365 & 10,068 & 7,931 & HS \\
\hline Hydrochloric Acid & 365 & 15,900 & 11,437 & HS \\
\hline Hydrofluoric Acid & 365 & 1,007 & 1,007 & EHS \\
\hline Nitric Acid & 365 & 11,359 & 9,959 & EHS \\
\hline Nitrogen & 365 & 320,000 & 295,621 & HS \\
\hline Phosphorus & 365 & 118 & 117 & EHS \\
\hline Sodium Hydroxide & 365 & 42,611 & 25,289 & HS \\
\hline Sulfuric Acid & 365 & 38,590 & 21,152 & EHS \\
\hline Toluene 2,4-Diisocyanate & 365 & 631 & 249 & EHS \\
\hline 1,1,1-Trichloroethane & 365 & 12,322 & 11,847 & HS \\
\hline Trichloroethylene & 365 & 17,046 & 16,572 & HS \\
\hline \multicolumn{5}{|l|}{ HS = Hazardous substance } \\
\hline EUS - Ext & baton & & & \\
\hline
\end{tabular}

\section{Section 313:}

The plant submits SARA Section 313 Reports, toxic release inventories by July 1 of each year for the previous years' release. Calender year 1993 SARA 313 report will be available July $1,1994$.

\subsection{Continuous Release Reporting}

There were no releases of hazardous substances or extremely hazardous substance reportable under CERCLA, at the Pinellas Plant in 1993. 
This page left blank intentionally. 


\subsection{Introduction}

In keeping with Specialty Components commitment to successfully administer an Environmental Management Program at the Pinellas Plant, the Environmental Management Division implemented a Groundwater Protection Management Program (GPMP). This program's goals are as follows: to determine baseline conditions of groundwater quality; to comply with and implement applicable regulations, laws, and DOE orders; to characterize and define trends in the physical and chemical condition of environmental media; to establish baselines of environmental quality; to detect groundwater pollution or contamination; to monitor potential groundwater contamination; and to apply environmental standards to protect human health and the environment.

Pinellas Plant GPMP developed a plan in accordance with the guidance of DOE 5400.1, Chapter III, and plans, permits and other technical documents, such as those associated with compliance with the SDWA, RCRA, HSWA, and CERCLA. This plan is reviewed annually and updated at least every three years. It includes, but is not limited to, characterizing groundwater at the Pinellas Plant; designing, documenting, and implementing a groundwater monitoring program; outlining strategies for managing groundwater protection and remediation; summarizing areas that may be contaminated with hazardous substances; and documenting strategies to address and clean up contaminants.

\section{Background}

Groundwater in the vicinity of the Pinellas Plant is encountered within several feet of land surface. Because of the silty, fine sand present from the surface to depths of approximately $\mathbf{3 0}$ feet, movement of groundwater is relatively slow. Lateral movement is less than several feet per year unless it is increased by discharge into surface water or by pumping. Downward movement of grcundwater from the surficial aquifer is retarded by a confining unit, the Hawthorn Formation. The Hawthorn is primarily clay and is approximately 65 fiet in thickness. This unit isolates the surficial sands from the underlying limestones of the Floridan Aquifer.

Monitoring wells are installed in the vicinity of the Pinellas Plant to measure groundwater elevation and water quality at various depths and locations in the surficial sands, the Hawthorn Formation, and the Floridan Aquifer. The wells are constructed within strict specifications to enable acmurate results for the evaluation of groundwater movement and quality. . Ionitoring wells are also installed in former waste management areas on and surrounding the plant site. Some monitoring wells are present near operating recovery wells and are used to monitor water level data and water quality. Monitoring wells are crucial for tracking the groundwater movement and evaluating the effectiveness of contaminated groundwater removal in the surficial sands. 


\subsection{Deaciption of the Ground wrater Monitorine Program}

The Groundwater Monitoring Program (GMP) at the plant is one module of the Environmental Monitoring Program (EMP). The GMP is administered by Specialty Components Environmental Management personnel, who coordinate and maintain third-party subcontractors to provide field and laboratory services. Subcontractors are required to follow EPA- and FDEP-approved sampling and analytical methodology. Groundwater sampling and analyses are either in response to a specific request for analysis, or as part of the on-going, routine quarterly sampling program.

Groundwater sampling is in accordance with a schedule that is reviewed annually and is subject to revision based on changes in regulatory requirements and reported groundwater quality data. The schedule includes the monitoring wells that are sampled, the frequency of sampling, and the contaminants that are analyzed. Pinellas Plant groundwater quality data are compared to drinking water standards that are set by the EPA and the FDEP. The more stringent of the two standards is used for comparison. Standards serve as a convenient reference, and if proposed standards exist for a contaminant, they may also be used as a reference.

Sampling methods, laboratory procedures, and the placement of monitoring wells and well screens all affect monitoring results, and the accuracy of instruments used to measure water quality may also vary. When results are lower than these levels, a laboratory may report them as BDL, or the result is indicated by a less than sign (e.g., <0.05). Based on these factors, a single reported value above a drinking water standard may be anomalous; therefore, it is important to look for patterns or trends in data. An anomaly may also result outside an observed trend, and if one occurs at a well, the well is resampled for verification.

Table 6-1 identifies the sampling episode, the parameters sampled, and the number of samples collected. All subcontracted laboratories performing analyses are certified by the HRS and the FDEP. Analytical results are submitted to Specialty Components Environmental Management personnel in both hard copy and electronic form. The draft data are compiled in a data base which is reviewed against historic data to evaluate trends in groundwater quality. The data base is used to organize and review data for analysis, reference, and documentation. Results are screened for manual errors with corrections made only with subcontractor concurrence, if applicable. 

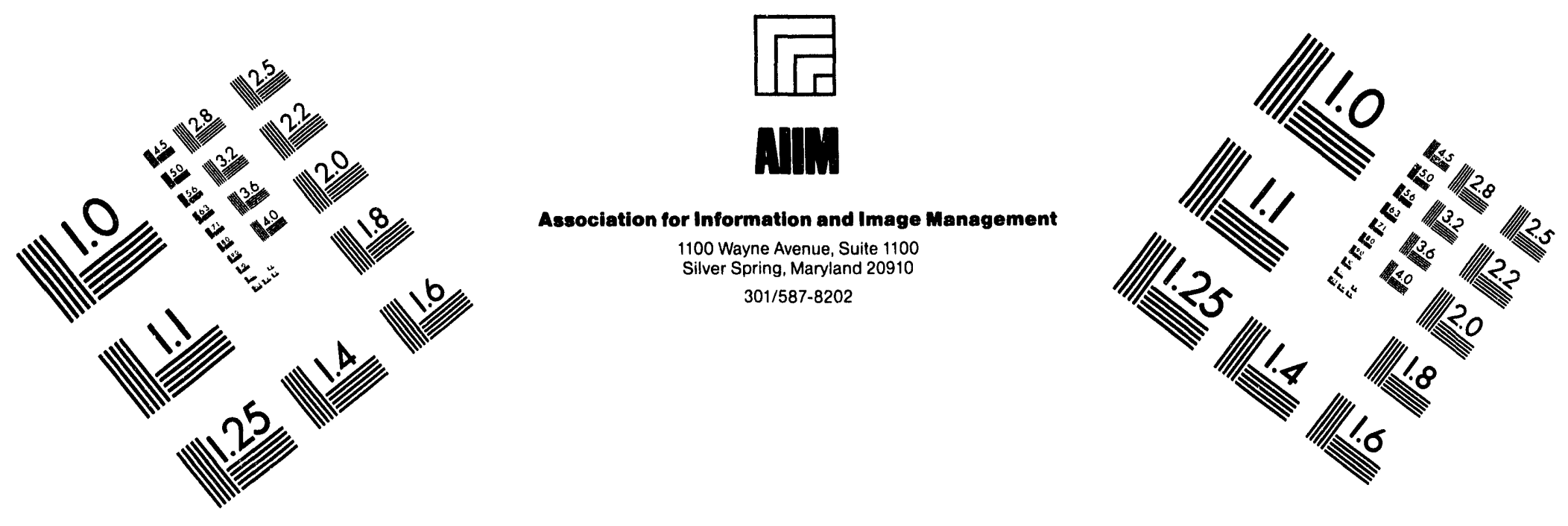

\section{Centimeter}

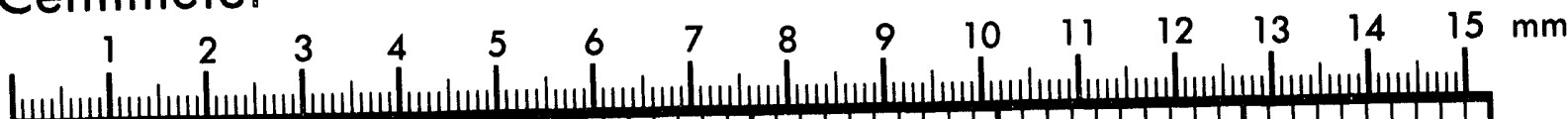

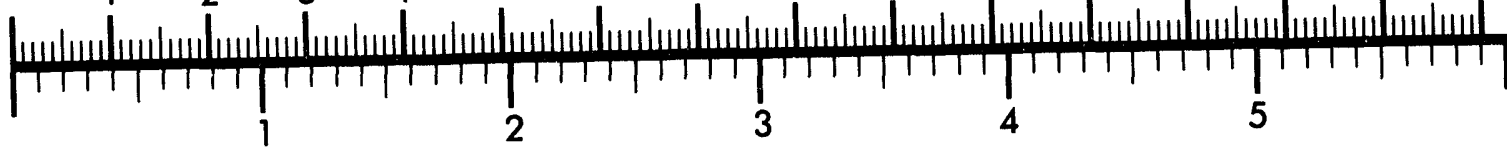
Inches
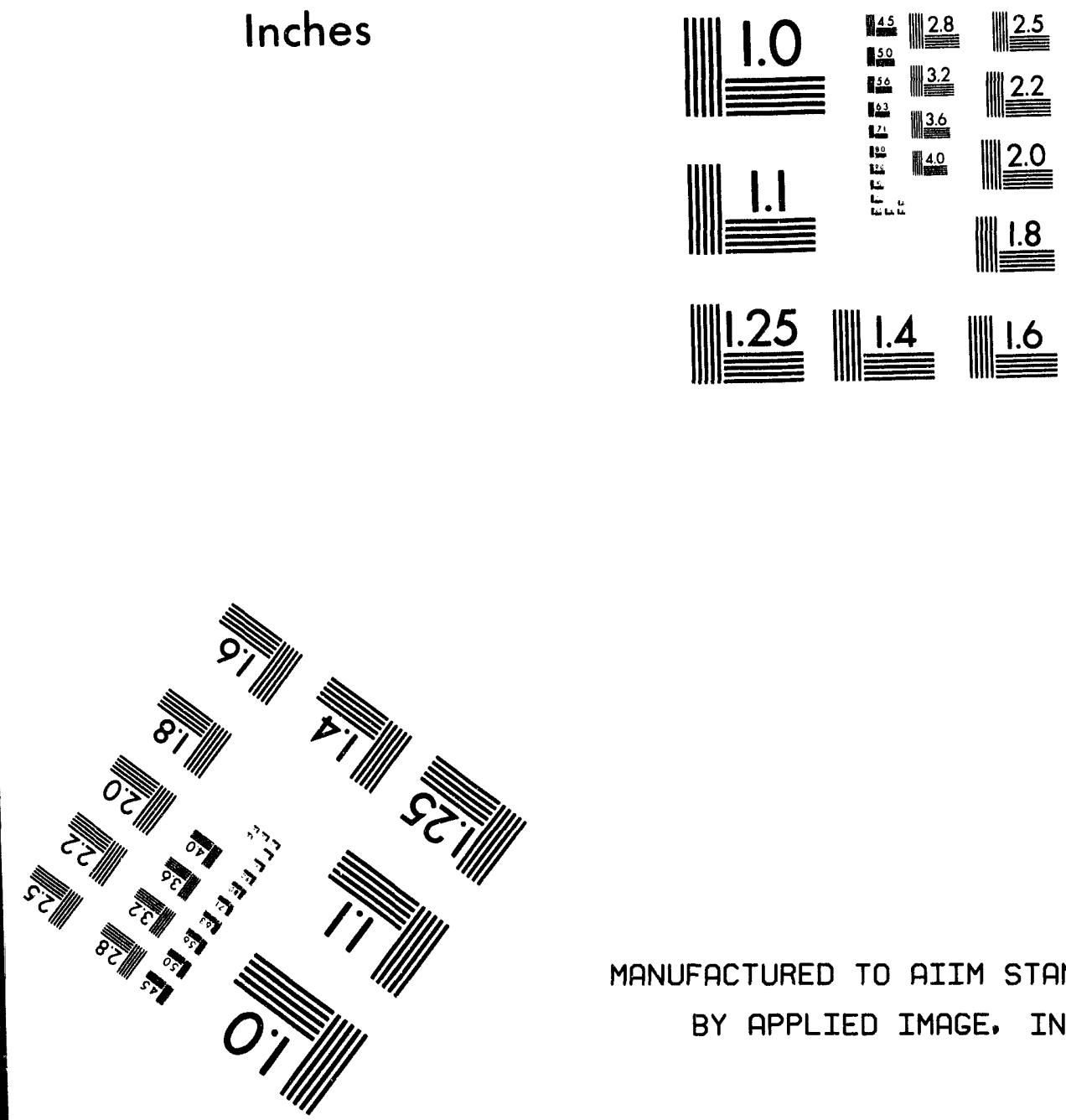

MANUFACTURED TO AIIM STANDARDS BY APPLIED IMAGE. INC.

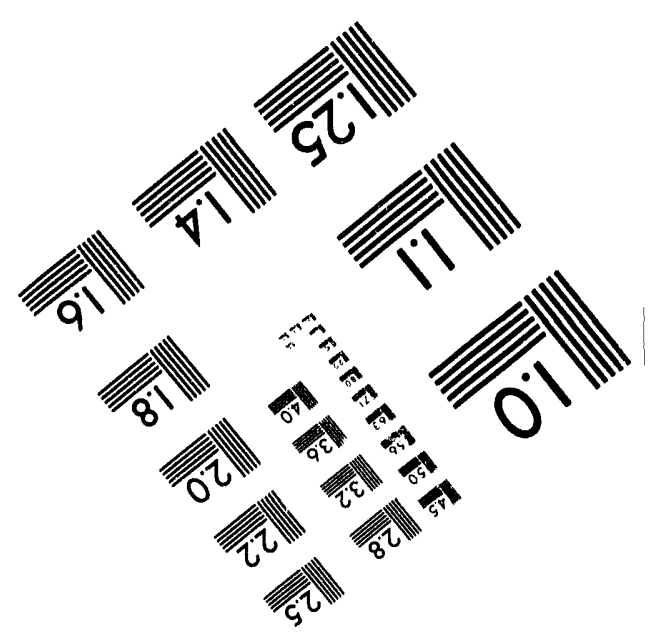



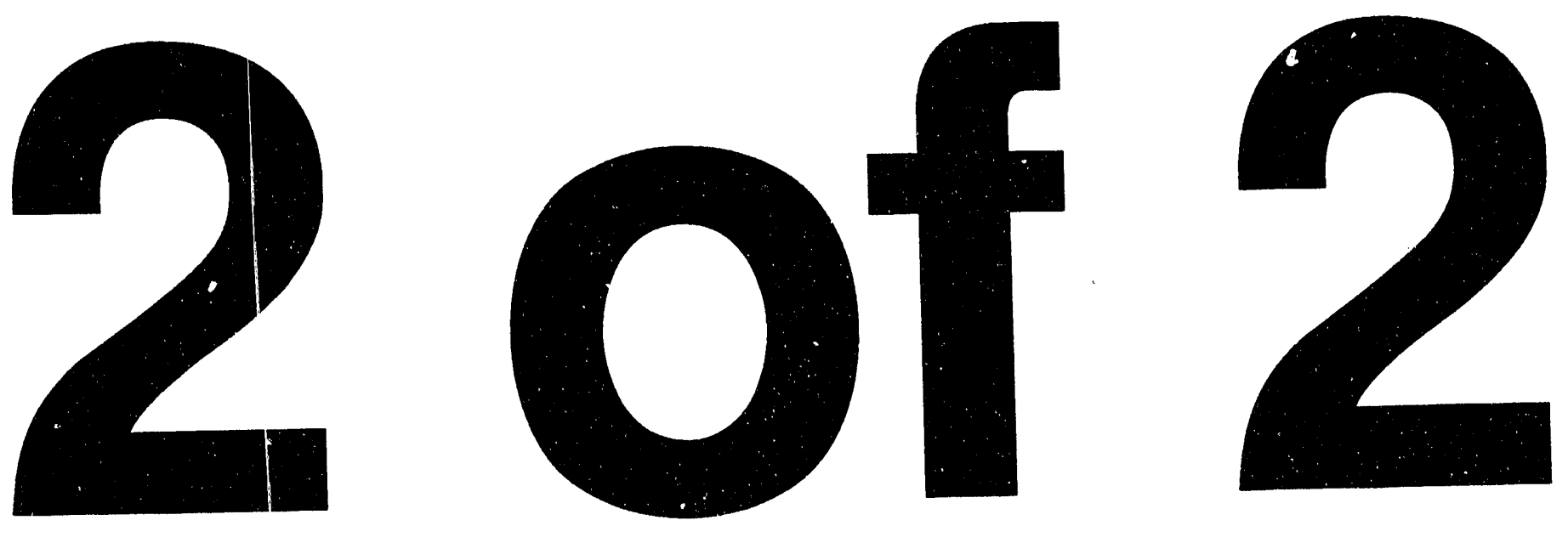
Table 6-1. Pinellas Plant Groundwater Monitoring Program

\begin{tabular}{|c|c|c|c|c|}
\hline Sampling Episode & VOCs & Metals & Tritium & Phenols \\
\hline January & 95 & 95 & 71 & 48 \\
\hline April & 95 & 0 & 39 & 0 \\
\hline July & 89 & 89 & 88 & 72 \\
\hline October & 97 & 9 & 45 & 0 \\
\hline
\end{tabular}

Once the screen and review cycle is complete, the draft report is finalized into a quarterly report which is submitted to DOE/PAO. The reports detail chemical trends in the monitoring wells, recovery well influent to the treatment system, and other pertinent data.

After remedial assessment and investigation, monitoring is discontinued at areas that pose no potential threat to the environment or public health and require no further action. An evaluation occurs before the subsequent annual sampling program to determine which areas are retained for further monitoring. Groundwater monitoring at the perimeter boundary of the Pinellas Plant and the Floridan Aquifer continue to demonstrate environmental compliance and protection.

\subsection{Hydrogeology}

The groundwater system underlying the Pinellas Plant has three primary water bearing units, as depicted in Figure 6-1. The upper saturated unit, the surficial aquifer, is associated with the upper $\mathbf{3 0}$ to $\mathbf{4 0}$ feet of undifferentiated sands. The surficial aquifer extends from approximately 5 feet below land surface to the top of the Hawthorn Formation, approximately 30 to 40 feet below land surface. The surficial deposits are primarily sand and shelly sand which grade into marl and sandy clay with increased depth. Groundwater in the surficial aquifer is unconfined; however, clay and/or silt layers and sand lenses exist within the surficial aquifer in the vicinity of the plant. Thus, hydraulic properties of the surficial aquifer can vary widely due to variations in the types and physical properties of material in the aquifer. Data generated as part of environmental restoration activities indicate approximate ranges. Some site specific hydraulic and geotechnical properties at the plant range as follows:

$\begin{array}{ll}\begin{array}{l}\text { Transmissivity } \\ \text { Horizontal Hydraulic Conductivity }\end{array} & 9-30 \mathrm{ft}^{2} / \text { day } \\ \begin{array}{l}\text { (Surficial Aquifer) } \\ \text { Vertical Hydraulic Conductivity }\end{array} & <1-4 \mathrm{ft} / \mathrm{day} \\ \begin{array}{l}\text { (Hawthorn) } \\ \text { Storage Coefficient }\end{array} & 0.001-0.00007 \mathrm{ft} / \mathrm{day} \\ \begin{array}{l}\text { (Surficial Aquifer) } \\ \text { Percent Sand } \\ \text { Percent Silt }\end{array} & <0.05-0.01 \\ & 23-78 \% \\ & 11-28 \%\end{array}$




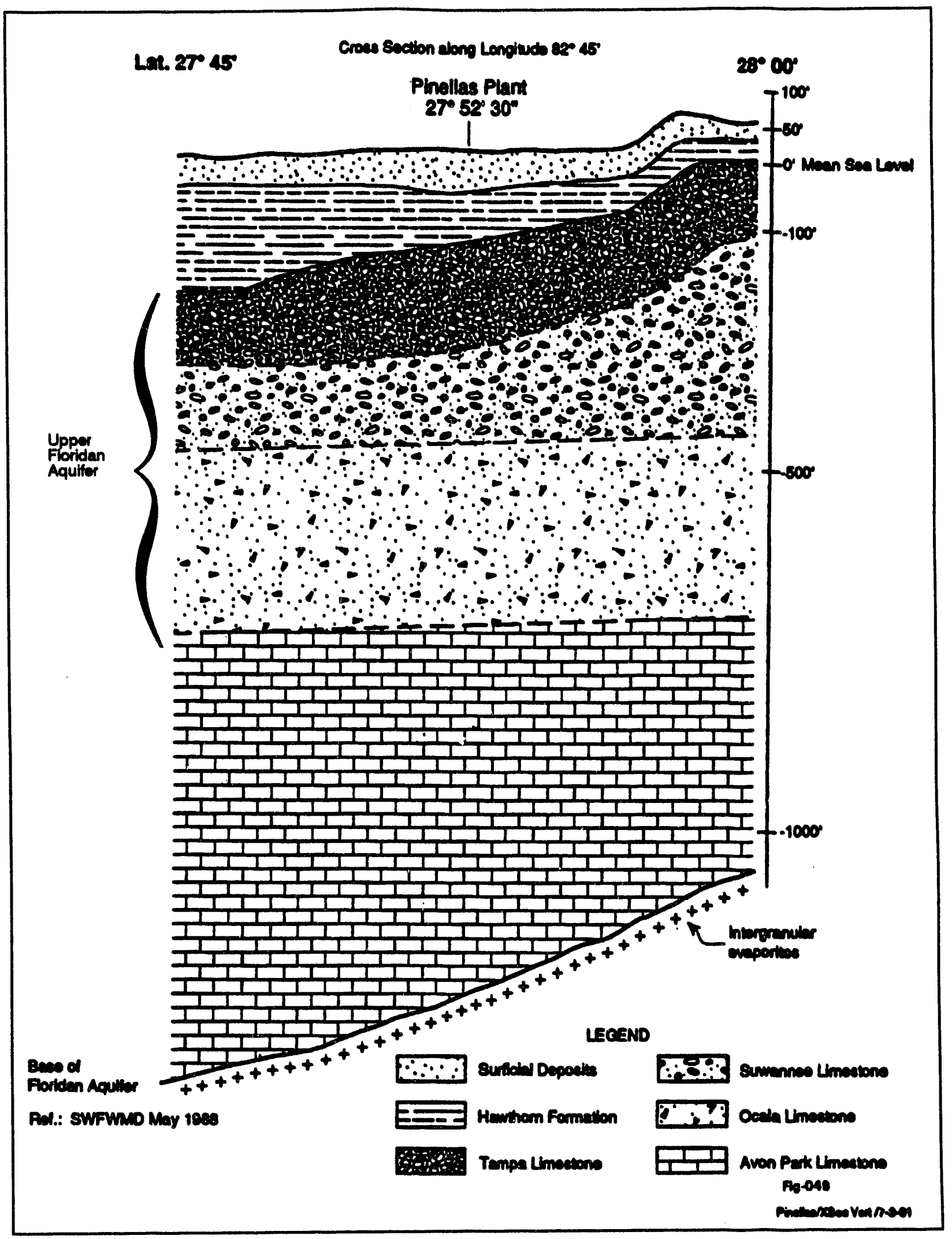

Figure 6-1. Generalized Geologic Cross Section in the Vicinity of the Pinellas Plant 
The potentiometric or groundwater surface of the surficial aquifer fluctuates approximately 1 to 4 feet seasonally. As shown in Figures 6-2 through 6-5, groundwater flow patteins across the plant remain relatively consistent throughout the year. Groundwater flow in the surficial aquifer is toward the northwest and southeast, away from a groundwater high that trends across the site from the northeast to the southwest. The East and West Ponds intercept the water table, but do not act as significant groundwater recharge bodies or discharge points. The West Pond receives no runoff, and a spillway controls levels in the East Pond.

Clays, fine-grained sandstone, and weathered limestone of the Hawthorn Formation underlay the surficial aquifer. Borehole logs of three Floridan monitoring wells on the plant property indicate the Hawthorn Formation is approximately 65 to 75 feet thick below the plant. The Hawthorn Formation is continuous across the plant property. Laboratory measurements of permeability samples collected from the Hawthorn Formation characterize it as an aquitard.

The major unit underlying the Hawthorn Formation is the Floridan Aquifer. The Floridan Aquifer is economically important because it is a municipal water supply source in northern Pinellas County. It is also a reservoir for the injection of reclaimed water and for small quantity domestic use (i.e., irrigation) in the county's central and southern portions. The Floridan Aquifer's groundwater becomes highly mineralized near the coast and with increasing depth. The top of the Floridan Aquifer occurs at approximately 100 feet below land surface at the Pinellas Plant. Deeper portions of this aquifer and regional groundwater flow, northeast toward Tampa Bay, are shown in Figure 6-6.

\subsection{Description and Groundwater Results of Areas of Potential Environmental Concern}

The Pinellas Plant GMP includes approximately 170 wells. Monitoring wells at the plant are screened in the surficial aquifer. Approximately 120 wells are used for water quality sampling. Except for three, all the wells sampled are screened within the surficial aquifer. Twenty-four wells are used to evaluate groundwater quality at the plant boundary. Three monitor the Floridan Aquifer, 27 monitor groundwater quality on an adjacent parcel of property (4.5 Acre Site), and the remaining monitor areas of potential environmental concern. These areas of concern include those identified by the EPA as SWMUs. Section 6.4 .5 references and describes these areas in detail. 


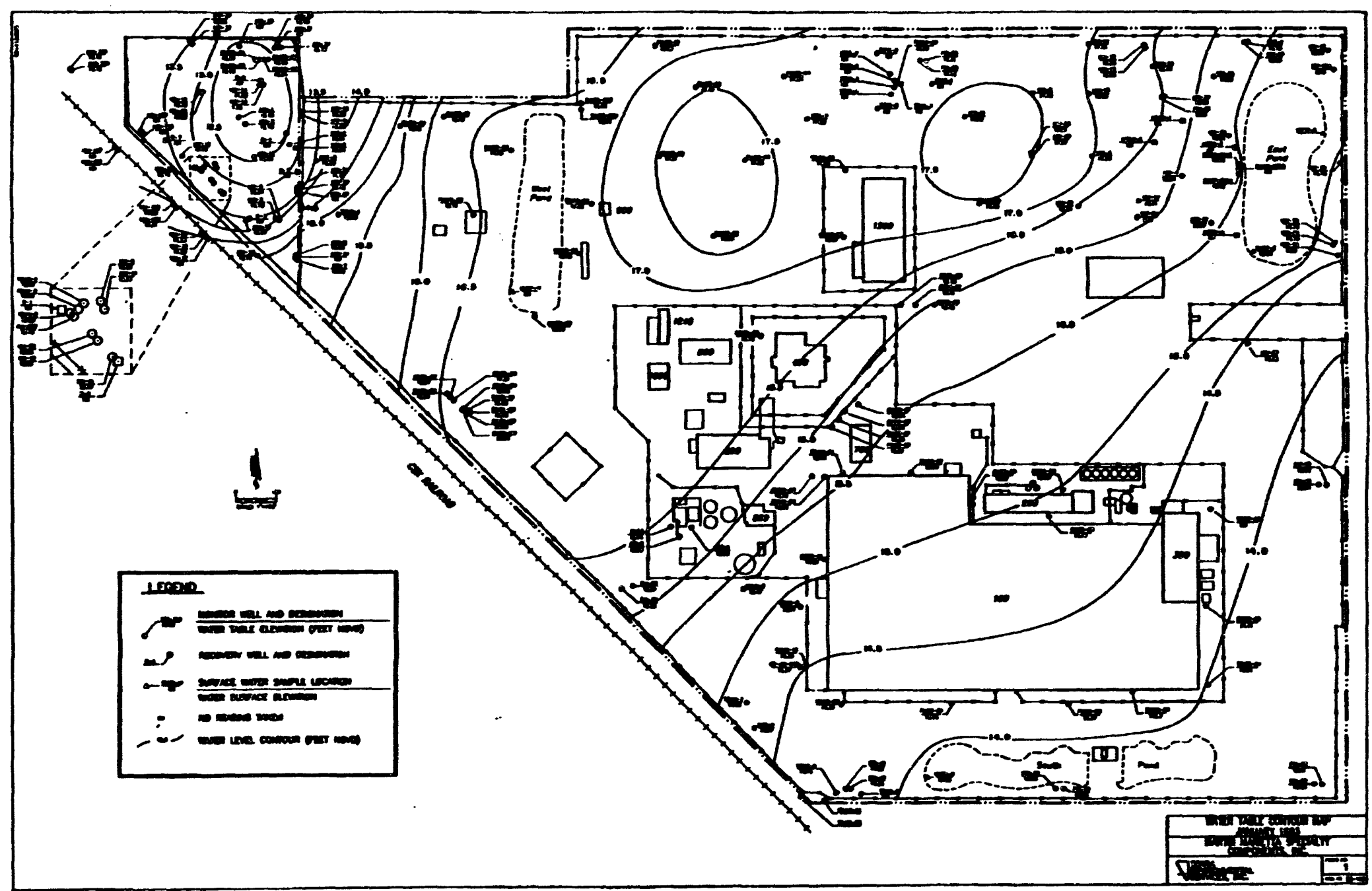

Figure 6-2. Water Table Map - January 1993 


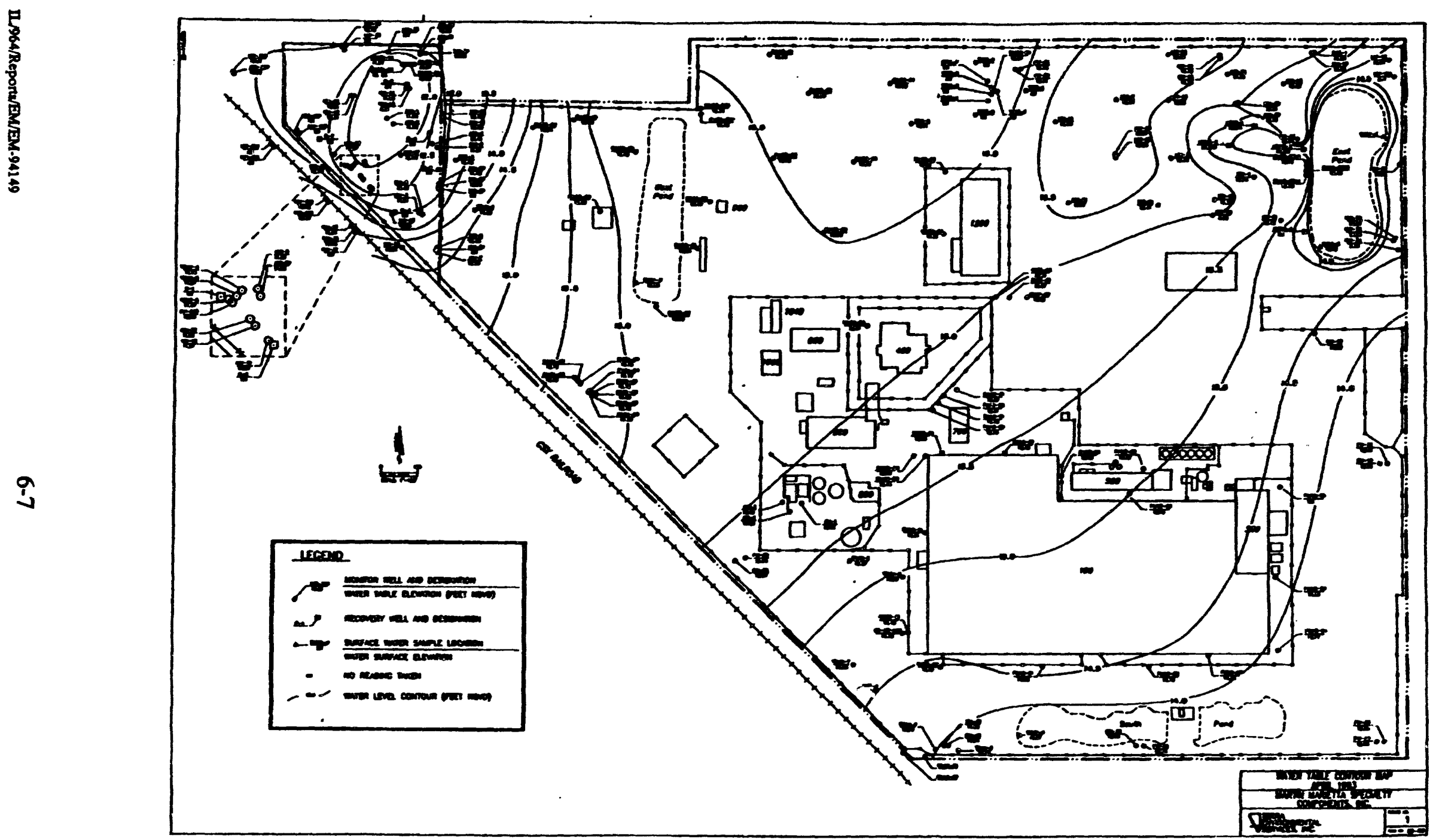

Figure 6-3. Water Table Map - April 1993 


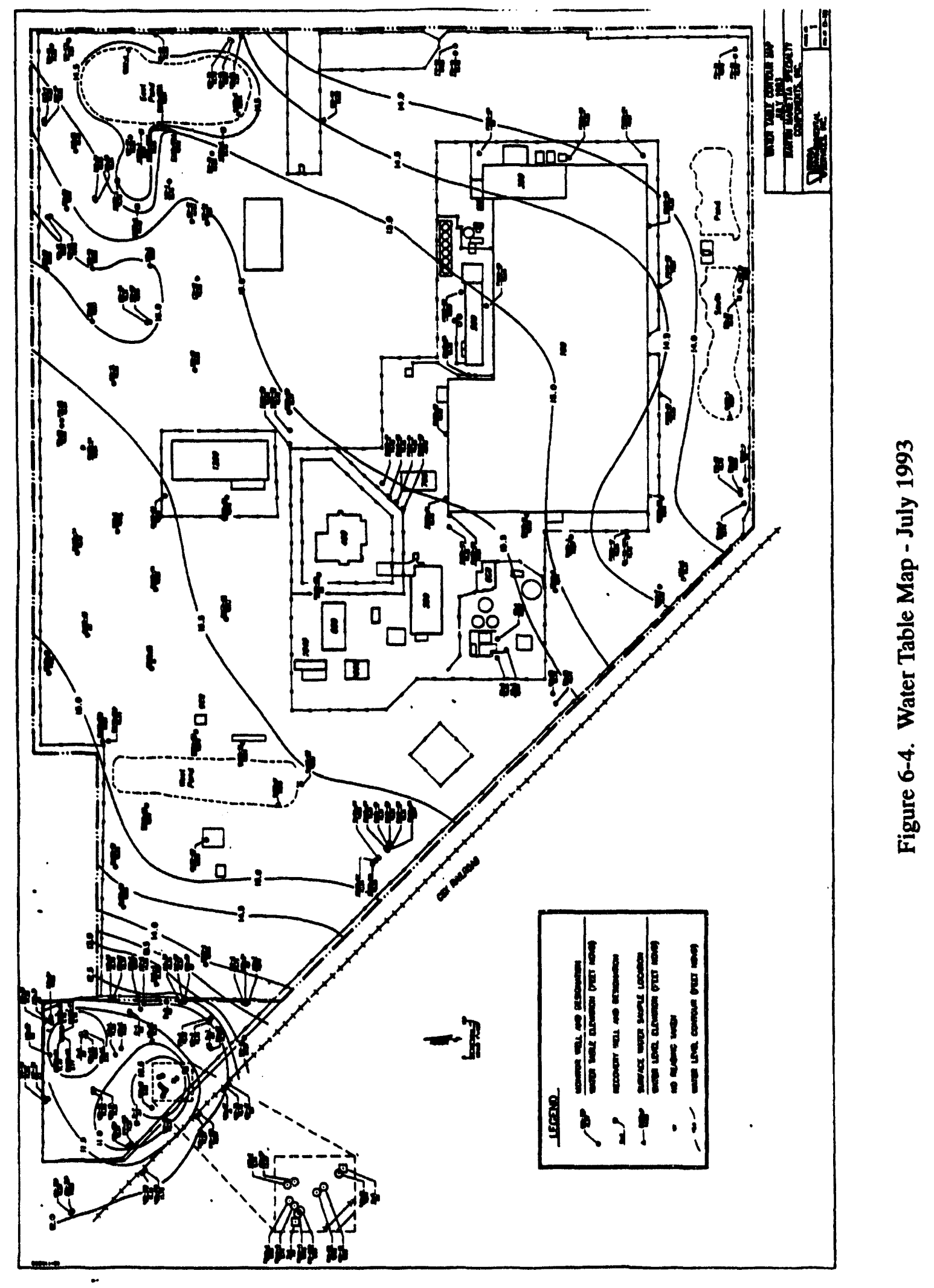




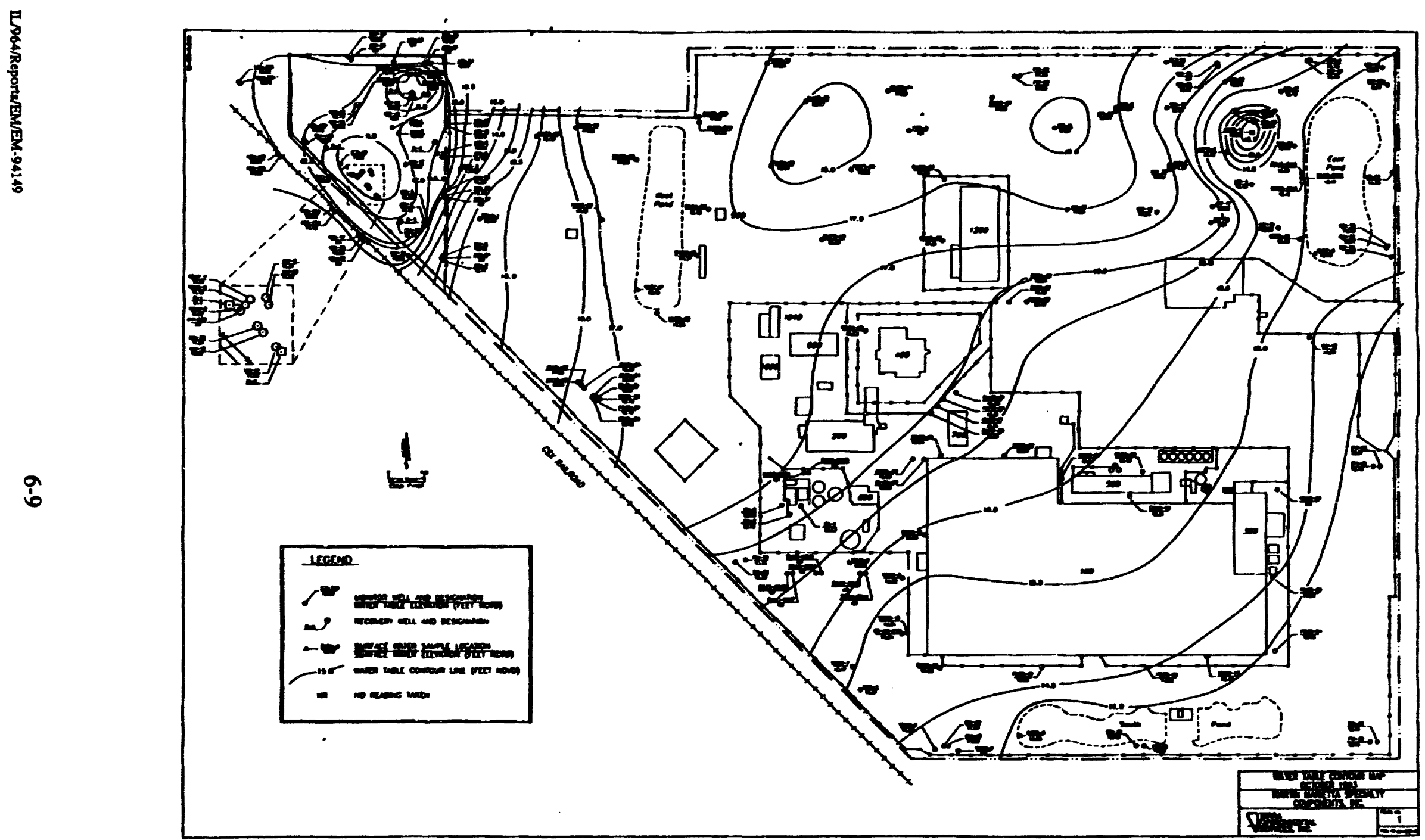

Figure 6-5. Water Table Map - October 1993 


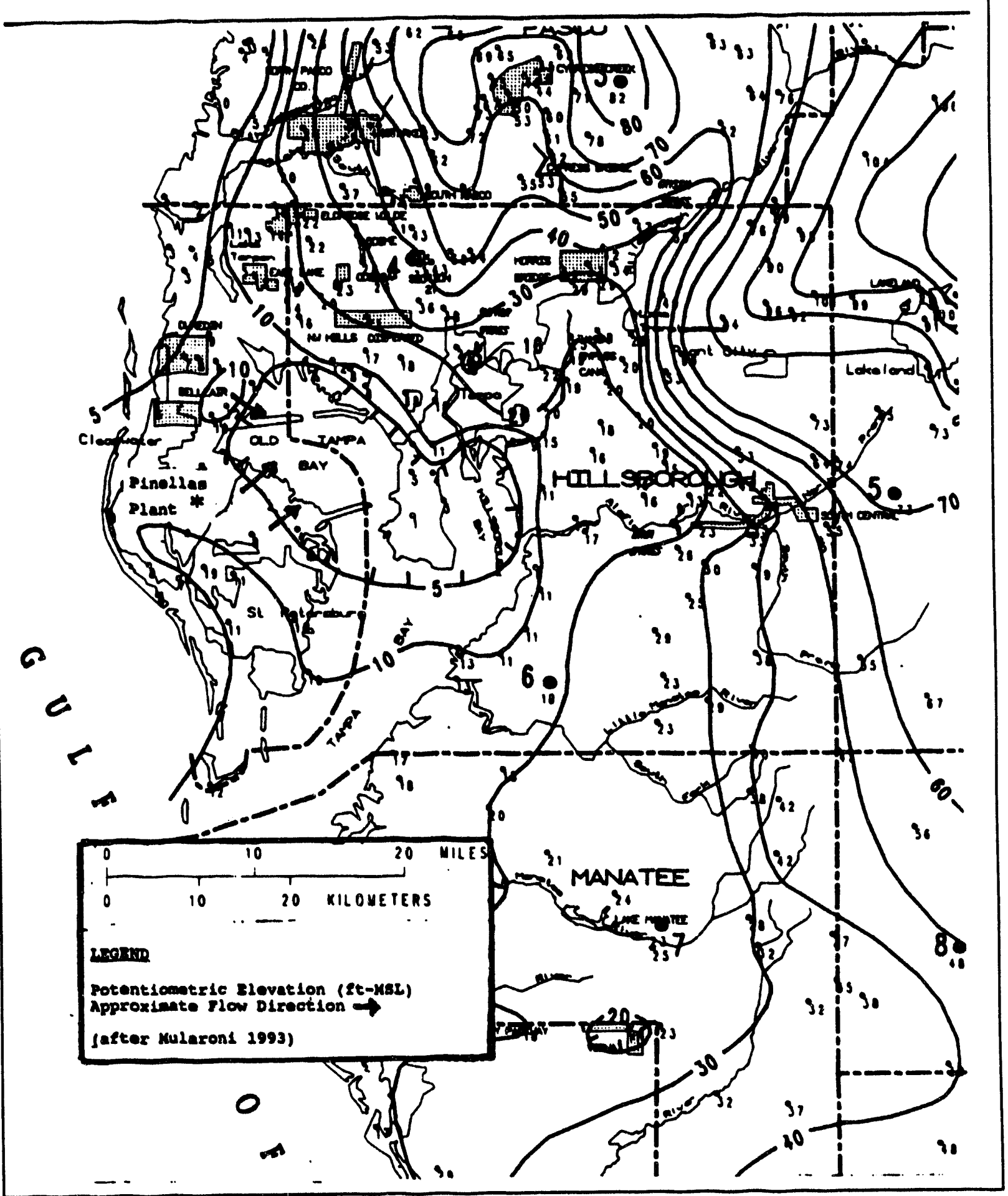

Figure 6-6. Potentiometric Surface of the Upper Floridan Aquifer,September 1992 
This section summarizes data generated by the Groundwater Monitoring Program and the findings and conclusions associated with the ER Program. Tables 6-2 through 6-4 present a summary of the analytical results from the samples that were collected.

Table 6-2. Tritium Groundwater Sample Concentrations (pCi/n)

\begin{tabular}{|l|c|c|c|c|}
\hline \multirow{2}{*}{ Parameter } & January & Apri & July & October \\
\cline { 2 - 5 } & Min/Max. & Min_/Max. & Min/Max. & Min_Max. \\
\hline Tritium (pCi//) & BDL/3.25 & BDL/2.78 & BDL/3.40 & BDL/3.68 \\
\hline $\begin{array}{l}\text { BDL - Below Detection Limit } \\
\text { NOTE - SDWA Maximum Contaminant Level(MCL) }=20 \mathrm{pCi} / 1\end{array}$ \\
\hline
\end{tabular}

Table 6-3. Metal Groundwater Sample Concentrations, $(\mu \mathrm{g} /)$

\begin{tabular}{|l|l|l|l|}
\hline Parameter & \multicolumn{1}{|c|}{ Standard* } & \multicolumn{1}{|c|}{ MDL** } & Maximum \\
\hline Antimony & $10(\mathrm{P})$ & $<60$ & $\mathrm{BDL}$ \\
\hline Arsenic & 50 & $<3.0$ & 31 \\
\hline Beryllium & $1.0(\mathrm{P})$ & $<1.0$ & $\mathrm{BDL}$ \\
\hline Cadmium & 10 & $<0.2$ & 9 \\
\hline Chromium & 50 & $<10$ & 60 \\
\hline Iron & 300 & $<20$ & 720,000 \\
\hline Lead & 50 & $<3.0$ & 140 \\
\hline Manganese & 50 & $<10$ & 2,600 \\
\hline Mercury & 2.0 & $<0.2$ & $\mathrm{BDL}$ \\
\hline Nickel & $100(\mathrm{P})$ & $<20$ & $\mathrm{BDL}$ \\
\hline Selenium & 10 & $<3.0$ & $\mathrm{BDL}$ \\
\hline Silver & 50 & $<10$ & $\mathrm{BDL}$ \\
\hline * SDWA - Maximum Contaminant Level and/or FDER \\
$\begin{array}{l}\text { Primary Drinking Water Standards } \mu \mathrm{g} / \\
\text { Minimum Detection Level (MDL) in } \mu \mathrm{g} /\end{array}$ \\
$\begin{array}{l}\text { (P) = indicates a proposed standard } \\
\text { BDL = Below detection limit }\end{array}$ \\
\hline
\end{tabular}


Table 6-4. VOC Groundwater Sample Concentrations, $(\mu \mathrm{g} /)$

\begin{tabular}{|l|l|l|l|l|}
\hline \multicolumn{1}{|c|}{ Parameter } & Standard* & MDL** & $\begin{array}{c}\text { Maximum } \\
1992\end{array}$ & $\begin{array}{l}\text { Maximum } \\
1993\end{array}$ \\
\hline 1,2-Dichloroethylene & 70 & 1 & 74,000 & 26,000 \\
\hline Benzene & 1.0 & 1 & 4,800 & 100 \\
\hline Dichloromethane & $5(\mathrm{P})$ & 3 & $2,700,000$ & $3,200,000$ \\
\hline Toluene & 1,000 & 1 & 44,000 & 14,000 \\
\hline Trichloroethene & 3.0 & 1 & 8,900 & 43,000 \\
\hline Vinyl Chloride & 1.0 & 1 & 42,000 & 19,000 \\
\hline $\begin{array}{l}\text { SDWA - Maximum Contaminant Level and/or FDEP } \\
\text { Primary Drinking Water Standards } \mu \mathrm{g} /\end{array}$ \\
$\begin{array}{l}\text { ** MDL in } \mu \mathrm{g} / \text { (P) } \\
\text { (P) = indicates a proposed standard }\end{array}$ \\
\hline
\end{tabular}

\subsubsection{Procedures and Results}

During 1993, plant personnel recorded groundwater elevation in all monitoring wells quarterly. During an 8-hour period every quarter, water levels were measured in all accessible wells and in the three surface water bodies. These measurements were documented in the field. Water table elevations are determined by subtracting the "depth to water" measurement from the top of the monitoring well casing elevation, surface water gauge, or reference elevation (surveyed points). All recorded elevations reference the MSL. The resulting elevations are used to prepare site specific surficial aquifer potentiometric maps (Figures 6-2 through 6-5). During 1993, surficial groundwater elevations ranged from a low of 13.0 feet above MSL during January and October, to a high of 18.0 feet above MSL in October, compared to 13.0 and 15.5 feet above MSL during 1992. The overall 1993 annual average groundwater elevation for the plant was 15.0 feet above MSL. This elevation was seven feet higher than water levels in the on-site Floridan Aquifer monitoring wells. Table 6-5 is a summary of groundwater elevation data. 
Table 6-5. Pinellas Plant Groundwater Elevation Data, (ft. above MSL)

\begin{tabular}{|l|l|l|l|}
\hline Month & Min & Max & Direction \\
\hline Surficial Aquifer & & & \\
\hline January & 13.0 & 17.5 & W\&SE \\
\hline April & 14.0 & 16.0 & W\&SE \\
\hline July & 14.0 & 15.5 & NW\&SE \\
\hline December & 13.0 & 18.0 & W\&SE \\
\hline Floridan Aquifer & & & \\
\hline January & 8.10 & 8.22 & NE \\
\hline April & 8.11 & 8.28 & NE \\
\hline July & 7.20 & 7.29 & NE \\
\hline December & 8.34 & 8.61 & NE \\
\hline
\end{tabular}

During 1993, groundwater field measurements for temperature ranged from 68 to 90 degrees Fahrenheit, with the average being 78 degrees Fahrenheit. Field measurements for $\mathrm{pH}$ ranged from 4.8 to 7.9 , with a 6.5 average. A maximum conductivity field measurement of $18,000 \mu \mathrm{mhos} / \mathrm{cm}$ was observed with a minimum measurement of $100 \mu \mathrm{mhos} / \mathrm{cm}$. The highest conductivity in a well at the Northeast Site rangel between 2,000 and $18,000 \mu \mathrm{mhos} / \mathrm{cm}$, which are significantly higher values than those seen in other samples collected in contaminated areas.

All samples except VOCs, were collected through Teflon tubing from monitoring wells purged with a peristaltic pump. A Teflon bailer attached to a disposable drop line was used to collect samples for VOC analysis. Floridan Aquifer monitoring wells were sampled with a Teflon bailer and drop line after purging was complete. Once samples were collected, they were placed in the appropriate containers with preservatives, if required, and stored in coolers with ice. Quality control samples, including equipment blanks, duplicates, splits, field blanks and trip blanks were also collected, as required by the applicable Comprehensive Quality Assurance Plan (ComQAP). Samples were sent to an HRS/FDEP-approved laboratory for analyses of various metals, VOCs, and phenols. The plant's Environmental Radiochemistry Laboratory analyzes the samples for tritium.

After each sample collection, the equipment used to evacuate and sample the monitoring well is thoroughly cleaned to minimize the potential for cross-contamination. This process is detailed in the quality assurance project and sampling and analysis plans. It consists of deionized water rinses, detergent scrubbing, dilute nitric acil rinses, isopropanol rinses, a final rinse with contaminant-free water, an 1 air drying. 
During 1993, 317 samples were collected from select monitoring wells for tritium analysis. These monitoring wells are strategically located around the perimeter of Building 100 and the plant perimeter, as well as other specific areas being investigated. The highest concentration of tritium found in the surficial aquifer was $3.68 \mathrm{pCi} / \mathrm{ml}$, which is significantly below the interim drinking water standard of $20 \mathrm{pCi} / \mathrm{ml}$. Most of the samples analyzed were BDL. Analysis of the Floridan Aquifer revealed no detectable levels of tritium.

Groundwater samples were collected from 96 monitoring wells and analyzed for 13 various trace metal concentrations. These metal analyses were total manganese $(\mathrm{Mn})$, iron ( $\mathrm{Fe})$, antimony $(\mathrm{Sb})$, lead $(\mathrm{Pb})$, selenium $(\mathrm{Se})$, nickel $(\mathrm{Ni})$, arsenic (As), cadmium (Cd), chromium ( $\mathrm{Cr}$ ), silver $(\mathrm{Ag})$, mercury $(\mathrm{Hg})$, beryllium $(\mathrm{Be})$ and thallium (Th).

Groundwater data obtained for the October 1993 sampling of the Former Pistol Range, PIN07-00, well indicated lead below the minimum detection limit ( 3 ug/). Some previous data had included lead levels ranging from BDL to $206 \mathrm{ug} /$. The $206 \mathrm{ug} / \mathrm{l}$ value was a result of the June 1990 sampling which was evaluated during the RFI data quality review (DOE 1991). Elevated levels (approximately $31 \mathrm{ug} /$ ) were reported for the January and July 1993 sampling events. This initially caused concern; however, the levels reported above the drinking witer standard $(15 \mathrm{ug} / \mathrm{l})$ resulted from sampling conditions. Variable conditions created by well purging and recharge can influence the results. Purging by peristaltic pump produced sample concentrations all below the standard of 15 $\mathrm{mg} /$. In addition, the last two sampling events that were conducted with low purge pumping rates, resulted in reported lead concentrations below the detection limit of 3 ug/. Because the 1993 lead in groundwater detections above the Florida Drinking Water Standard are artifacts of the well purging method, the Pinellas Plant maintains its recommendation for No Further Action (NFA).

The plant found trace metals at levels which exceed EPA or FDEP drinking water standards as follows: manganese, iron, lead, and chromium. At many locations, elevated concentrations of manganese and iron are attributed to natural conditions of the surficial aquifer. The presence of buried reinforcing bar and other metal may contribute to results reported at some locations. Areas associated with these wells are being investigated under the plant's Environmental Restoration Program (Sections 6.4.4 through 6.4.5).

In 1991, 126 samples were analyzed for PCBs, PAH and/or pesticides. Because the results were either BDL, below regulatory levels of concern, or not identified as contaminants of concern by the ER Program, groundwater analyses of these parameters were discontinued in 1992.

No compounds in the phenol analytical group were detected in the 144 samples collected and analyzed. In 1992, the previous year, phenol and 4-chloro 3-methylphenol were detected. If the absence of phenol in the samples collected continues, further curtailment of phenol analyses will remain under consideration. 
Volatile organic compound concentrations in groundwater represent the primary environmental contaminants at the Pinellas Plant. Of the ccnstituents measured by each analysis, only seven were detected in the samples. Of these seven compounds, five compounds were detected at the highest levels when sampled from recovery wells. Table 6-6 is a summary of the results of these analyses and shows an annual decline in concentrations of most compounds.

Table 6-6. 4.5 Acre Site Historic High versus Current High, $(\mu g /)$

\begin{tabular}{|l|l|l|l|}
\hline $\begin{array}{l}\text { Volatile Organic } \\
\text { Compound }\end{array}$ & $\begin{array}{l}\text { Historic High } \\
\text { Concentration }\end{array}$ & $\begin{array}{l}\text { Current High } \\
\text { Concentration }\end{array}$ & $\begin{array}{l}\text { Percent } \\
\text { Reduction }\end{array}$ \\
\hline $1,1-$ Dichloroethane & 43 & BDL & $>99 \%$ \\
\hline 1,2-Dichloroethylene & 74,000 & 19,000 & $46 \%$ \\
\hline Trichloroethene & 320,000 & 4 & $>99 \%$ \\
\hline Tetrachloroethane & 880 & $\mathrm{BDL}$ & $>99 \%$ \\
\hline Dichloromethane & 680,000 & 2,700 & $99 \%$ \\
\hline Vinyl Chloride & 79,000 & 17,000 & $78 \%$ \\
\hline Toluene & 44,000 & 14,000 & $68 \%$ \\
\hline Ethyl Benzene & 15 & $\mathrm{BDL}$ & $>99 \%$ \\
\hline Xylene & 5,200 & $\mathrm{BDL}$ & $>99 \%$ \\
\hline * Only result not showing a decline from previous year. & \\
\hline
\end{tabular}

The above compounds included cis and trans 1,2-dichloroethylene (1,2-DCE), trichloroethene (TCE), dichloromethane, vinyl chloride (a degradation product), benzene and toluene. These compounds were detected above drinking water standards. All areas associated with elevated levels of volatile organic compounds are under investigation or corrective action. In addition, the areas with high concentrations (the 4.5 Acre Site and the Northeast Site) have an interim groundwater remedial action underway (Sections 6.4.4 through 6.4.5).

\subsubsection{Floridan Aquifer}

Three monitoring wells on Pinellas Plant property are screened in the upper Floridan Aquifer. These wells are located along the property boundary and immediately outside the most contaminated area of the Northeast Site. An impact to the Floridan Aquifer by the plant's current or past operations can be detected by monitoring these wells.

As in 1992, no compounds were detected at or above any drinking water standards this year, with the exception of iron. Iron is naturally present at high concentrations. To date, no contaminants have been detected in the Floridan 
Aquifer monitoring wells with the exception of one sampling episode in 1987 and one in 1993. In both years, trace levels of acetone and methylene chloride, common laboratory solvents, were detected. Verification sampling revealed no detectable concentrations of acetone; therefore, these isolated incidents were attributed to laboratory artifacts.

\subsubsection{Perimeter Survelllance Network}

The perimeter monitoring well network, completed September 1991, Figure 6-7, monitors the surficial aquifer. Twelve well clusters installed around the perimeter of the plant consist of two or more wells at different depths of the aquifer. During 1993, no trace metals, with the exception of manganese and iron, or phenol compounds were detected above drinking water standards. In these wells, the only compound detected above MCLs in the perimeter well network was the volatile organic compound vinyl chloride. Vinyl chloride was detected at trace levels in perimeter monitoring wells 5S and 5D, located on the west property boundary (West Fenceline) just north of the west parking lot. This area was added to the ER Program for corrective measure and further investigation (Section 6.4.5).

\subsection{Acre Site}

ER Program activities at the Pinellas Plant were initiated in mid-1984, in response to the DOE Operations Office, Albuquerques' Comprehensive Environmental Assessment and Response Program (CEARP). The program's major emphasis was on past waste management practices that resulted in an adverse environmental impact, and whether corrective actions were needed.

The CEARP also assisted DOE in setting environmental priorities and provided justification for funding to carry out remedial actions or enhancements to existing responses if required. This program was initiated to help fulfill DOE's commitment to have all its facilities operate under a policy of full compliance with applicable environmental regulations. Through records searches, literature reviews, employee interviews, preliminary assessments, and site inspections, the CEARP identified 14 potential sites for further investigation. Thirteen of the 14 sites, plus some additional areas, are individually identified SWMUs, and either were investigated or are being investigated pursuant to the plant's HSWA Permit (Section 6.4.5). 


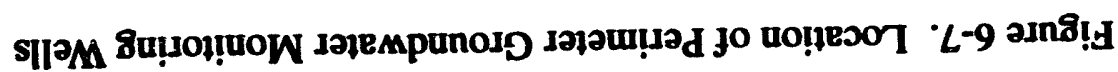

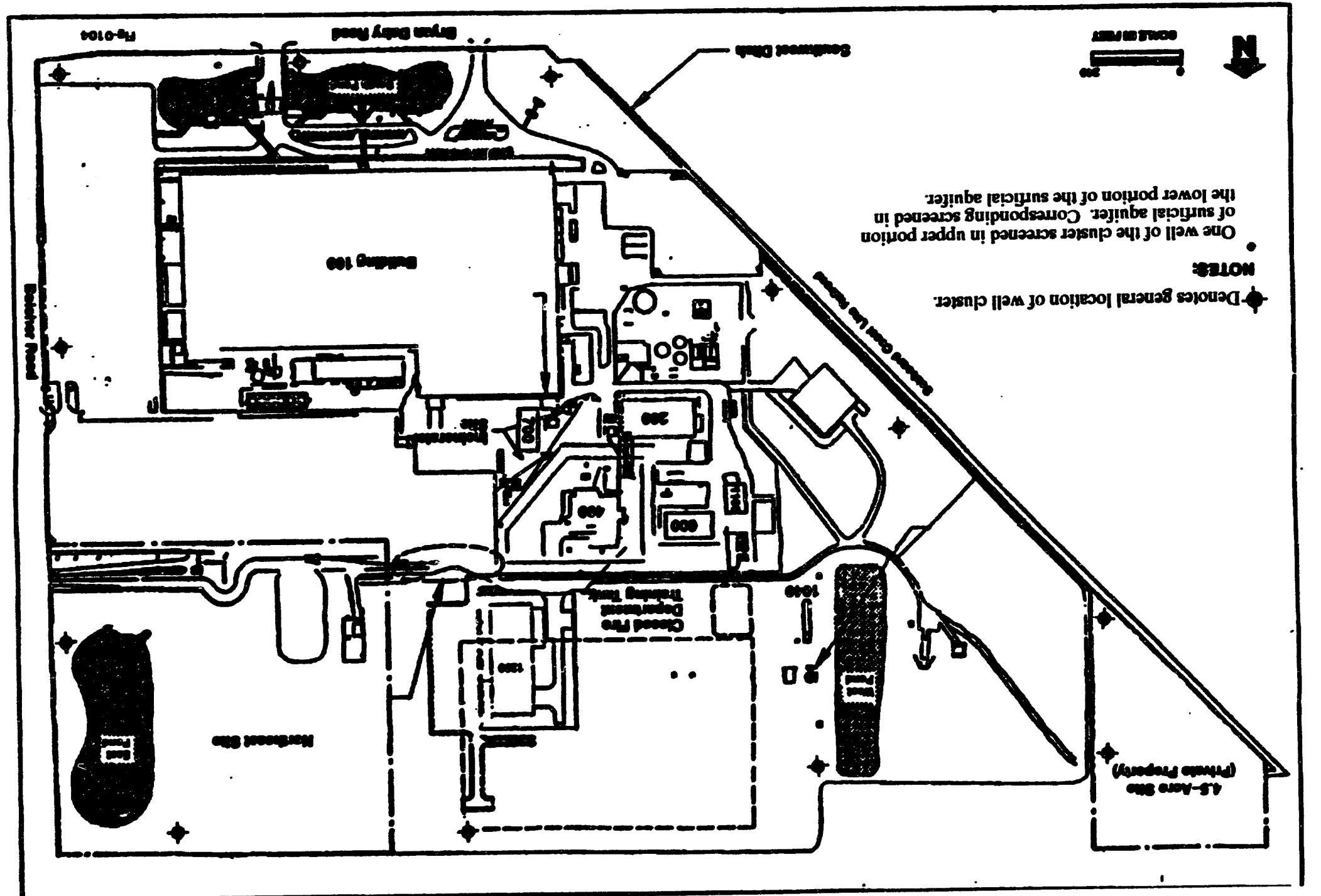


The resin drum disposal area (or the 4.5 Acre Site) is not regulated as a SWMU. This area, however, was identified as the highest priority environmental restoration site. Drums filled with resin and solvent waste from plant operations were disposed of in an area northwest of the present site boundary in the early 1960s, Figure 6-8. Disposal activities consisted of excavation, placement of drums, and back-filling. The land was subsequently sold to a private individual in 1972. Confirmation of these activities occurred in 1985, when the U.S. Geologic Survey was commissioned to perform a surface geophysical survey of this area to ascertain if drums were present. During devegetation activities at the site, the top of one crum was found buried at the immediate surface. The contents were methylc ae chloride with other trace contaminants. Subsequently, a detailed, voluntary assessment and source removal activity authorized by the FDEP commenced. A total of 83 drums were exhumed, and approximately 300 tons of contaminated waste and soils were disposed of at the Pinewood, South Carolina hazardous waste landfill.

After the source material was removed, the piant conducted a series of studies to identify the areal extent of groundwater contamination resulting from drum leakage. The Pinellas Plant voluntarily followed all FDEP activity and reporting requirements for groundwater cleanup cases. These activities were initiated and/or considered complete upon FDEP written approval, even though no consent order or other formal compliance agreement was issued. The Contamination Assessment Report and Feasibility Study Work Plan were submitted to the FDEP in August 1986, and approved in March 1987. The Feasibility Study Report was submitted and subsequently approved October 1987. During the feasibility study, Interim Remedial Action (IRA) was warranted due to the off-site migration of contaminated groundwater. An IRA plan was submitted and approved in May 1988. The design and construction of the IRA and Volatile Organic Compound Treatment System was completed May 1990.

The 4.5 Acre Site Volatile Organic Compound Treatment System was constructed adjacent to the 4.5 Acre Site on Pinellas Plant property. Construction of the system was completed on April 23, 1990. A pre-startup iest, conducted May 9, 1990 , passed with no foreseeable problems. Upon IRA implementation, the Pinellas Plant initiated a monitoring and groundwater sampling and analysis program. The monitoring program consists of groundwater elevation monitoring and benchmark surveying to monitor land surface elevation and potential subsidence along the off-site railroad tracks. The sampling and analysis program incorporates select on-site and off-site monitoring wells and the seven recovery wells. This program characterizes the contaminant plume configuration and trends in contaminant concentrations. 


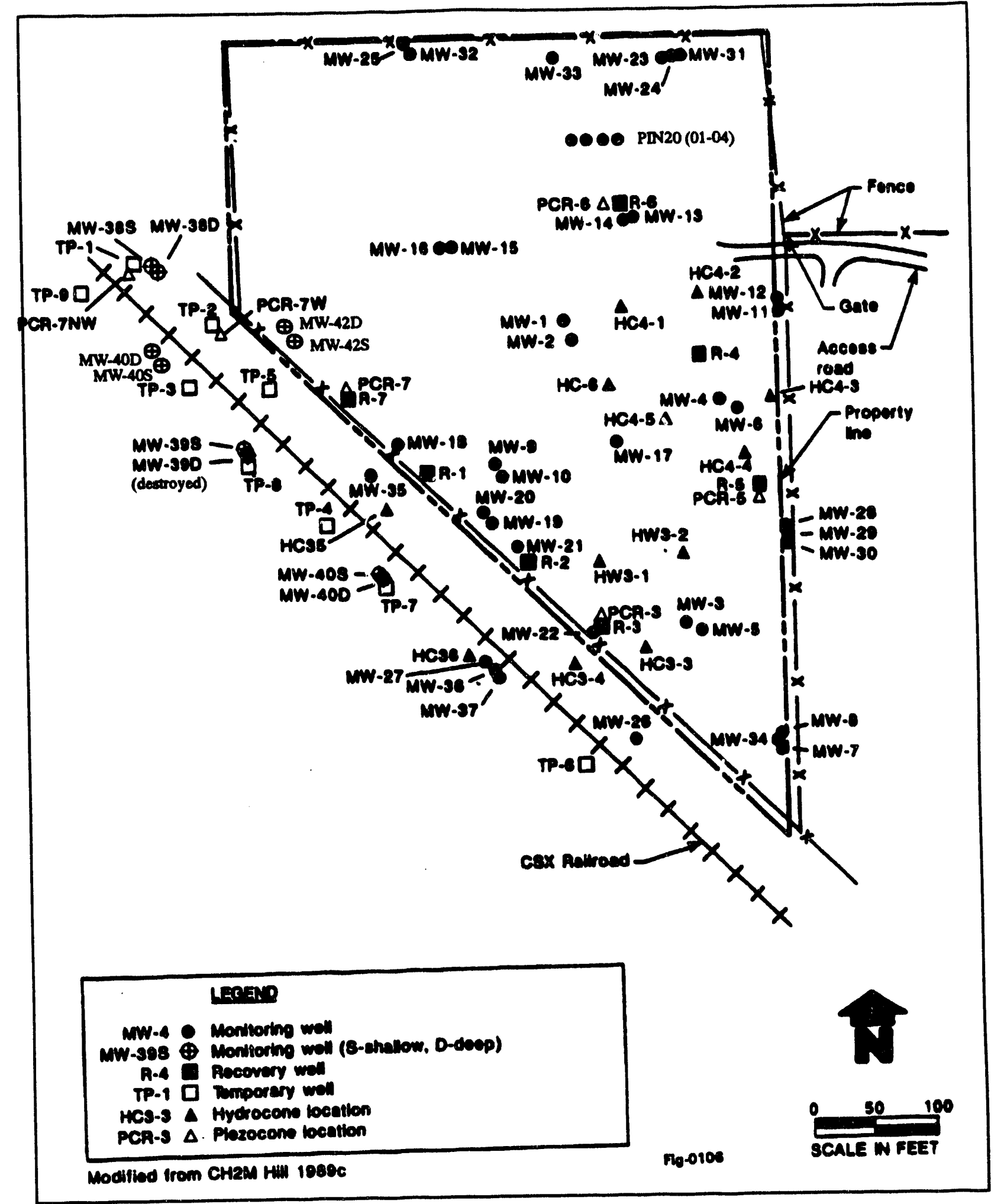

Figure 6-8. Location of Groundwater Monitoring Wells, Piezocone and Hydrocone Sampling 
During 1993, ER activities relating to the 4.5 Acre Site primarily consisted of continued operation and maintenance of the VOC treatment system. Institution of a treatment system upgrade of the filter press increased operational efficiency.

As of December 31, 1993, approximately 3.5 years of IRAs were completed. Approximately 15.8 million gallons of groundwater were recovered and treated. Significant levels of contaminants continue to be captured from the recovered groundwater. A downward trend in contaminant concentrations is evident.

During 1993, a total of 54 trace metal samples, 58 tritium samples, 50 phenol samples and 108 volatile organic compound samples were collected from the selected monitoring wells.

The only trace metals that exceeded drinking water standards were lead, iron (secondary standard), and chromium. Lead was detected once in monitoring well $4.5 \mathrm{MW}-4$ at $100 \mathrm{ug} /$. Iron, commonly found at high concentrations in the surficial aquifer, was reported as high as $45 \mathrm{mg} /$ in a recovery well. The drinking water standard for lead is $15 \mu /$. No detectable concentrations of phenol compounds were reported.

On average during 1993, six of the 22 monitoring wells sampled on a quarterly basis had volatile organic concentrations. Total volatile concentrations ranged from approximately 1 to $50,000 \mathrm{ug} / \mathrm{l}$ in the wells. The highest concentration reported at monitoring well $4.5 \mathrm{MW}-4$ may have resulted from decreased recovery rate at the nearby $4.5 \mathrm{RW}-4$ well.

Overall, significant reductions in VOC concentrations occurred since implementation of the IRA in on-site, as well as off-site, monitoring wells. Data obtained to $12 / 31 / 93$, indicate the interim action is an effective and efficient groundwater recovery and treatment system.

The 4.5 Acre Site's recovery system altered the surficial aquifer's hydraulic gradient and flow direction at critical locations. This alteration of the surficial aquifer is a result of the successful extraction of groundwater. Surveying results indicate no subsidence occurred along the railroad tracks of the 4.5 Acre Site.

The Pinellas Plant successfully stabilized the VOC contaminant plume as a direct result of the pump and treat methodology employed at the 4.5 Acre Site. The interim action also reduced the areal extent and magnitude of the total VOC concentrations within the plume. Interim remedial actions will continue until final remedial actions are approved by the FDEP and implemented by the plant. Figures 6-9 through 6-11 show concentrations of total VOCs in wells at the 4.5 Acre Site, which are used to interpret the extent of off-site contamination and as indicators of remediation effectiveness. 


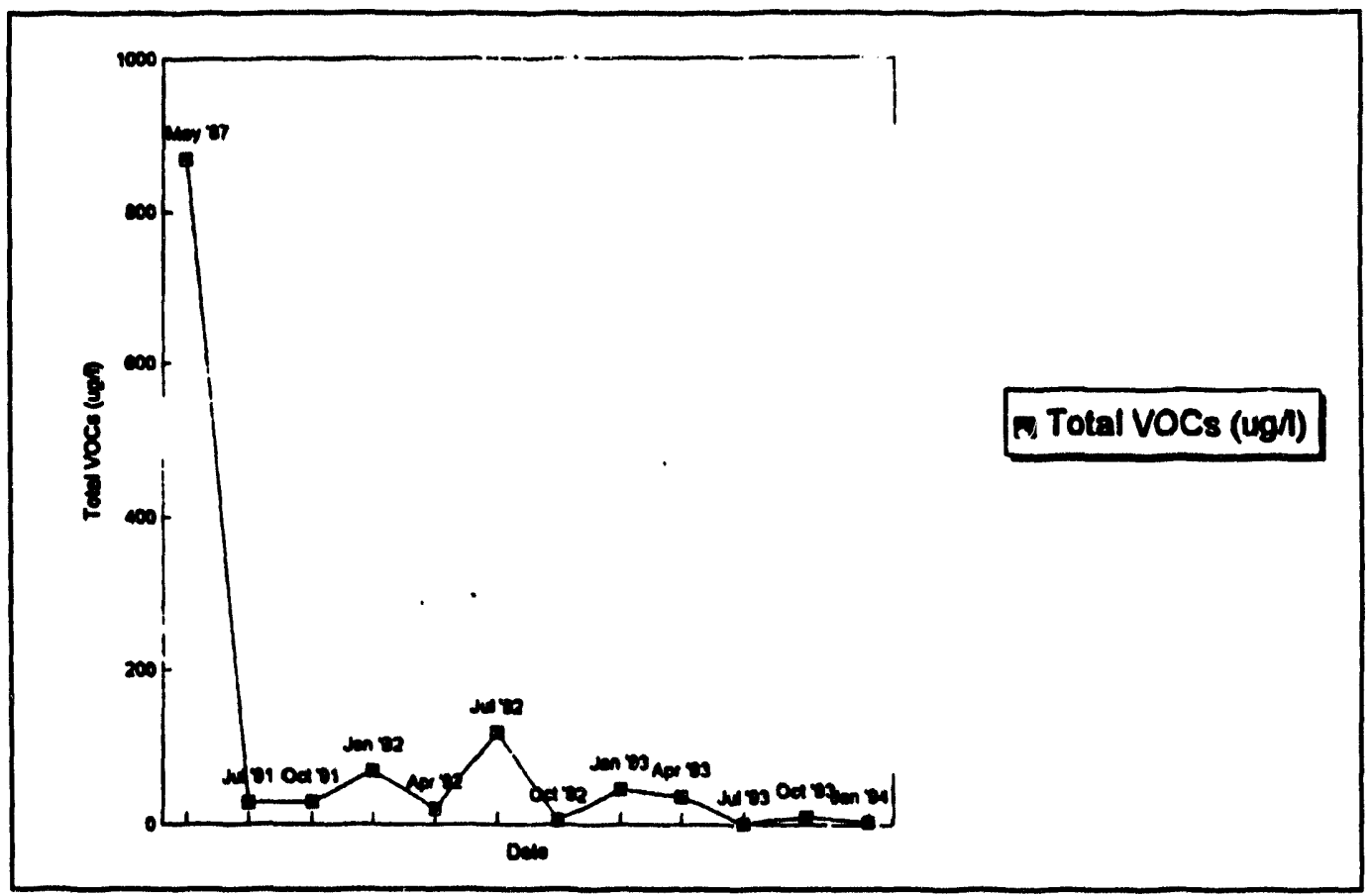

Figure 6-9. Chemical Time Series Graph - Monitoring Well 4.5 MW-18

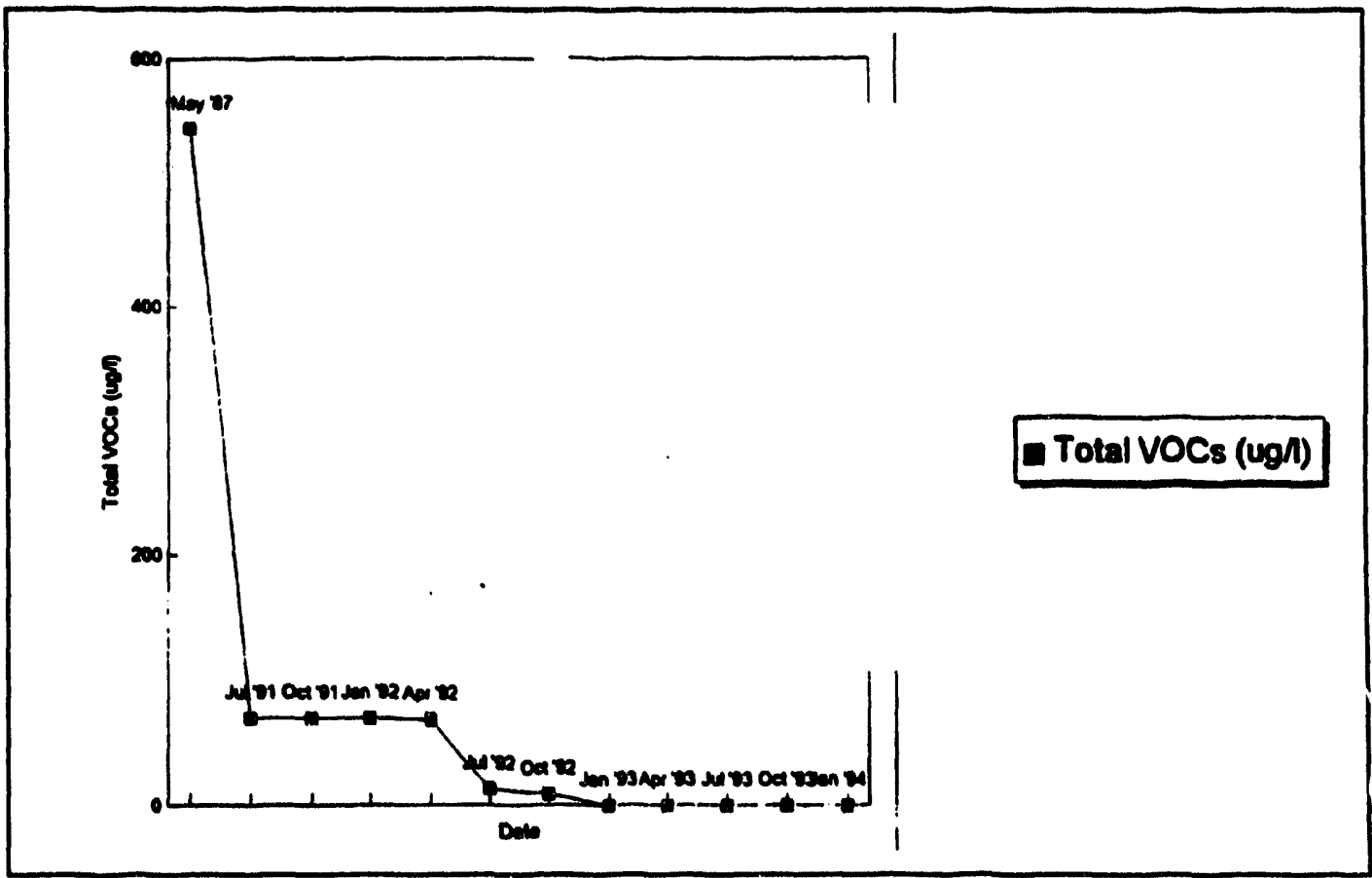

Figure 6-10. Chemical Time Series Graph - Monitoring Well 4.5 MW-20 


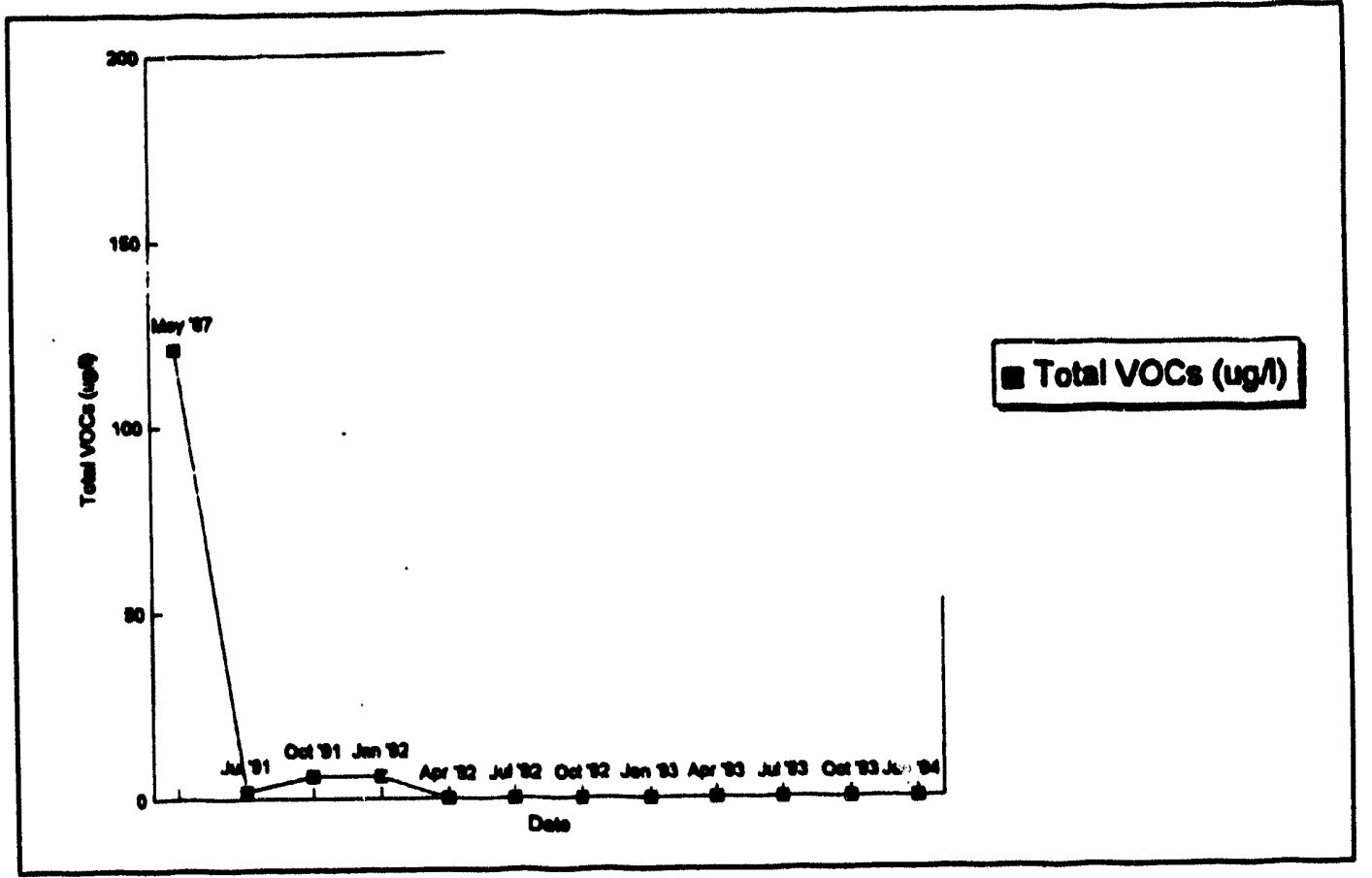

Figure 6-11. Chemical Time Series Graph - Monitoring Well 4.5 MW-27

The air impacts associated with the groundwater treatment facility are minimal and well below State calculated standards. The Maximum Ambient Concentrations (MAC) of the major groundwater contaminants were calculated per FDEP guidance, and the results indicate values well below the FDEP Acceptable Ambient Concentrations (AAC).

\subsubsection{Solid Waste Management Units (or Miscellaneous Sites)}

While ER activities were being conducted at the 4.5 Acre Site, other on-site activities were conducted to evaluate "miscellaneous sites" identified during the CEARP. A majority of this work focused on the Northeast Site, a former waste drum staging area. A Contamination Assessment Report (CAR) was developed and submitted to the FDEP for review and subsequent approval. Approval was granted October 1987. The feasibility study was initiated and completed; however, prior to FDEP submittal, EPA exercised jurisdiction over the miscellaneous sites utilizing its HSWA authority. Prior to EPA issuance of the HSWA Permit, received in February 1990, development of the RFI Work Plan was initiated. This work plan identified all investigatory activities to assess and determine the extent of any environmental impacts associated with current and past waste management practices. All known sites of potential environmental concerns were identified in the Pinellas Plant's HSWA Permit as SWMUs.

Table 6-7 includes a brief description of each of the SWMUs investigated and Figure 6-12 shows the general location of each of the solid waste management units. 
Table 6-7. Pinellas Plant SWMUs

\begin{tabular}{|c|c|}
\hline SWMU & Description \\
\hline West Pond (PIN 02)* & $\begin{array}{l}\text { Man-made pond that received pH-neutralized industrial effluent and tertiary } \\
\text { treated sanitary sewage from 1972-1982. }\end{array}$ \\
\hline $\begin{array}{l}\text { Spray Imigation Site } \\
\text { (PIN 03)* }\end{array}$ & $\begin{array}{l}\text { Land treatment site for pH-neutralized industrial effluent and tertiary treated } \\
\text { sanitary sewage from 1972-1982. }\end{array}$ \\
\hline Trench Site (PIN CF) & $\begin{array}{l}\text { Trenches purported to have received slurry waste from water softeners in the } \\
\text { late } 1950 \text { s. }\end{array}$ \\
\hline $\begin{array}{l}\text { Old Drum Storage } \\
\text { Site (PIN 06) }\end{array}$ & $\begin{array}{l}\text { Site of a storage pad for empty drums formerly containing waste solvents. Pad } \\
\text { was removed in } 1983 \text {. }\end{array}$ \\
\hline $\begin{array}{l}\text { Pistol Range } \\
\text { (PIN 07)* }\end{array}$ & Former small-arms firing range for plant guards; removed in 1988. \\
\hline $\begin{array}{l}\text { Closed Fire Dept. } \\
\text { Training Tank } \\
\text { (PIN 08)* }\end{array}$ & Former location of fire training tank used by plant's fire brigade. \\
\hline $\begin{array}{l}\text { Current Fire Dept. } \\
\text { Training Tank } \\
\text { (PIN 14)* }\end{array}$ & Current location of fire training tank used by plant's fire brigade. \\
\hline $\begin{array}{l}\text { Metallic Anomaly } \\
\text { (PIN 04)* }\end{array}$ & $\begin{array}{l}\text { Area associated with a metallic anomaly identified during an electromagnetic } \\
\text { survey performed by the United States Geological Survey (USGS) in } 1985 \text {. }\end{array}$ \\
\hline $\begin{array}{l}\text { Incineration Site } \\
\text { (PIN 09)* }\end{array}$ & Locations associated with incinerators formerly located at the Pinellas Plant. \\
\hline $\begin{array}{l}\text { Incineration Ditch } \\
\text { (PIN 10) }\end{array}$ & $\begin{array}{l}\text { Ditch that formerly received incinerator scrubber water and suspected disposal } \\
\text { of small quantities of waste solvents. }\end{array}$ \\
\hline $\begin{array}{l}\text { Diesel Fuel Spill } \\
\text { (PIN 11)* }\end{array}$ & Location of diesel fuel spill that occurred in 1983. \\
\hline $\begin{array}{l}\text { Industrial Drain } \\
\text { Leaks, BIdg. } 100 \\
\text { (PIN 12) }\end{array}$ & $\begin{array}{l}\text { Areas beneath Building } 100 \text { where potential leaks have occurred from the in- } \\
\text { dustrial and health physics drain system. }\end{array}$ \\
\hline $\begin{array}{l}\text { Southwest Ditch } \\
\text { (PIN 13)* }\end{array}$ & $\begin{array}{l}\text { Location of former industrial and sanitary effluent outfalls from the Pinellas } \\
\text { Plant. The outfalls operated from the beginning of operations at the plant } \\
\text { (1954) until 1968. }\end{array}$ \\
\hline $\begin{array}{l}\text { Northeast Site } \\
\text { (PIN 15) }\end{array}$ & $\begin{array}{l}\text { The Northeast Site is associated including the with the location of a former } \\
\text { waste east pond solvent staging and storage area. The east pond received pH- } \\
\text { neutralized industrial waste and tertiary treated sanitary waste from } 1968 \text { to } \\
1972 \text {. }\end{array}$ \\
\hline $\begin{array}{l}\text { Building } 500 \text { Spill } \\
\text { Site (PIN 16)* }\end{array}$ & $\begin{array}{l}\text { Located north of Building } 500 \text {. Former location of an oil drain associated with } \\
\text { compressor blow down. }\end{array}$ \\
\hline $\begin{array}{l}\text { West Fenceline Area } \\
\text { (PIN 17) }\end{array}$ & $\begin{array}{l}\text { An area between the western property boundary and the Wastewater Neutraliza- } \\
\text { tion Area with low levels of VOCs in the groundwater. Source of contamina- } \\
\text { tion is suspected to be a former dumpster area. }\end{array}$ \\
\hline
\end{tabular}




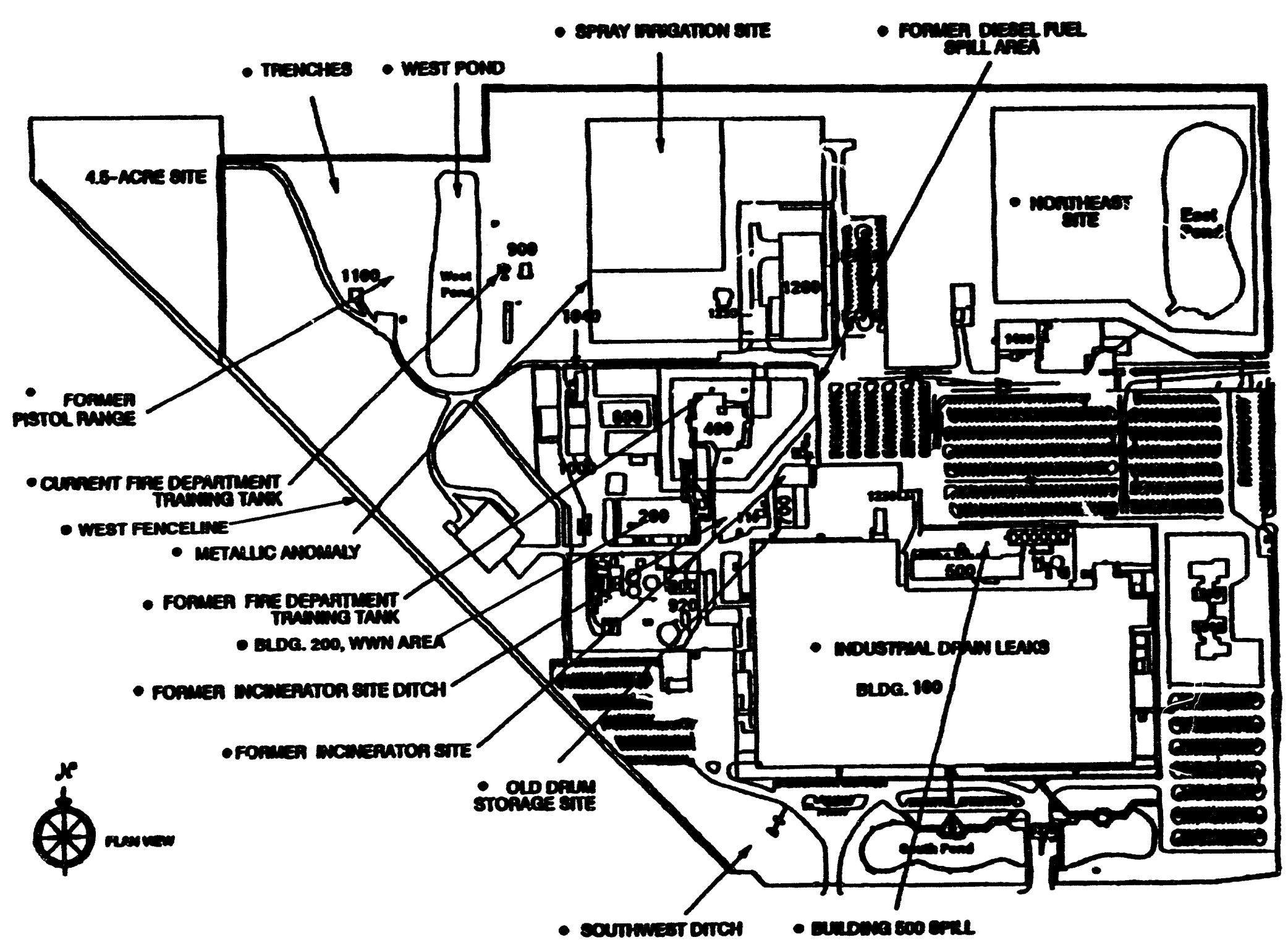

Figure 6-12. Areas of Potential Environmental Concern at the Pinellas Plant 
Figure 6-13 indicates the regulatory steps required to complete remedial action under HISWA. Each "step" includes the following: 1) the development, submittal, and EPA approval of a work plan which delineates the activities to complete, methods of completion, rationale, and justification for that method; 2) the actual field work, investigation and/or study activities; and 3) the preparation, submittal, and EPA approvel of a final report. Under each step in Figure 6-13, are statements relative to the requirements of that step and the current status of the Pinellas Plant as of December 31, 1993.

The ER Program strategy is to initiate and complete as much documentation development and field work as practical, while the regulatory agency is in the process of reviewing the previously submitted document. For example, document development of the Corrective Measures Study Plan (CMSP) was initiated prior to final EPA approval of the RFI report. This strategy is one factor that accounts for the quick progression of the plant's ER Program.

Figure 6-13 depicts the progression of environmental restoration activities associated with the miscellaneous sites. Specifically, the plant completed investigation of the fifteen SWMUs in accordance with the HSWA portion of the plant's RCRA permit. The plant submitted a draft RFI Report to EPA in September 1991, as required. The RFI concluded the plant's current and past operations did not impact the Floridan Aquifer and recommended four of the $\mathbf{1 6}$ SWMUs (PIN 07, PIN 06, PIN 12, and PIN 15) for a CMS. The RFI identified eleven SWMUs for no further action (NFA) based on the results of site characterization. Pursuant to EPA comments, an addendum to this report was submitted in March 1992.

In May 1992, EPA provided the plant with a conditional approval of the RFI Report which included the following: 1) concurrence that the plant did not impact the Floridan Aquifer, 2) concurrence with the four SWMUs that require a CMS, 3) identification of the additional monitoring requirements at four SWMUs, and 4) identification of the remaining SWMUs that required no further action. The additional monitoring requirements were completed. ER monitoring activities revealed no contaminants above regulatory standards, and in 1993, a report was submitted to the EPA.

In July 1992, a CMSP was submitted to EPA for the four SWMUs requiring a CMS. The plan stated three individual CMSs would be prepared; one for the Former Pistol Range, one for the Northeast Site, and one combining Building 100 and the Old Drum Storage Pad. Industrial Drain Leaks, Building 100, and the Old Drum Storage Pad were combined due to the proximity (co-location) of the sites to each other and the similar contaminant of concern identified during the RFI. EPA comments on the CMS Plan were received, addressed, and in November 1992, an addendum was submitted to the plan. Work on two of the CMSs, Building 100/Old Drum Storage Pad, and the Northeast Site Addendum was initiated in late 1992, with regulatory submittal anticipated in early 1994. 


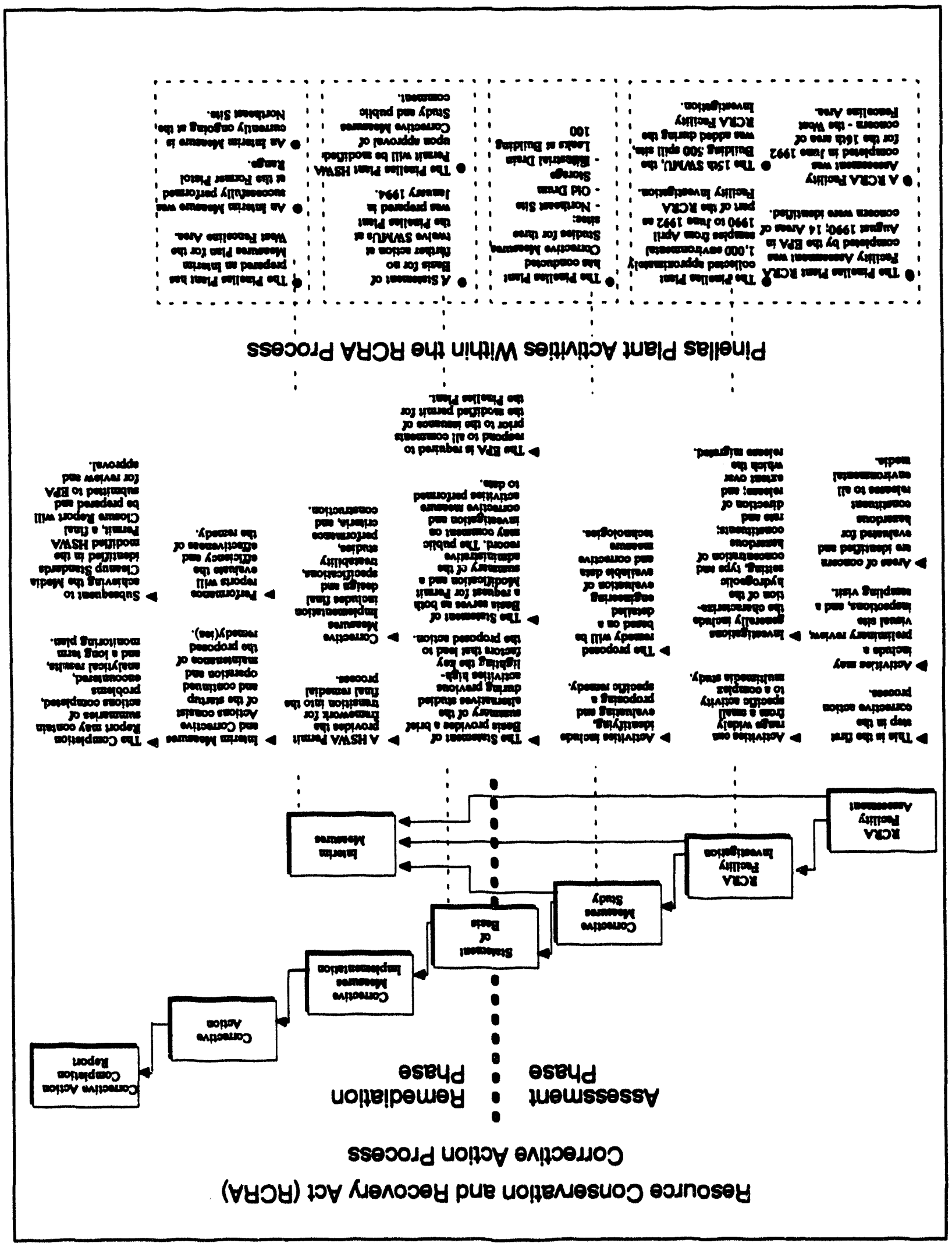


During January and February 1993, 473 tons of lead- contaminated soil was excavated from the top foot of the land surface to reduce the lead in the soil to naturally occurring levels pursuant to an EPA-approved interim corrective measures plan. The soil was subsequently stabilized and disposed of at an EPA-approved hazardous waste facility. The interim measure was completed on March 12, 1993, satisfying the requirements of conditions II.D.6 of the Pinellas Plant HSWA Permit. A September 1993 Statement of Basis summarizing information presented in the RFI and interim measure was submitted to the EPA recommending no further action at the Former Pistol Range. In addition to this action, the Northeast Site is currently undergoing interim measures in accordance with the permit and under approval of the EPA Regional Administrator. The plant is submitting quarterly performance reports to the EPA, as required.

Figures 6-14 through 6-18 show concentrations of total VOCs in selected wells at the Northeast Site. Wells NEMW-2D and 21 show a general decline in concentrations to trace levels or below detection limits ( 0 ug/l on graph). Other wells show a variable trend, usually an overall decline. This is evident for wells NEMW-2S, 3, and 4. Such variation will be addressed in the final corrective measures at this site.

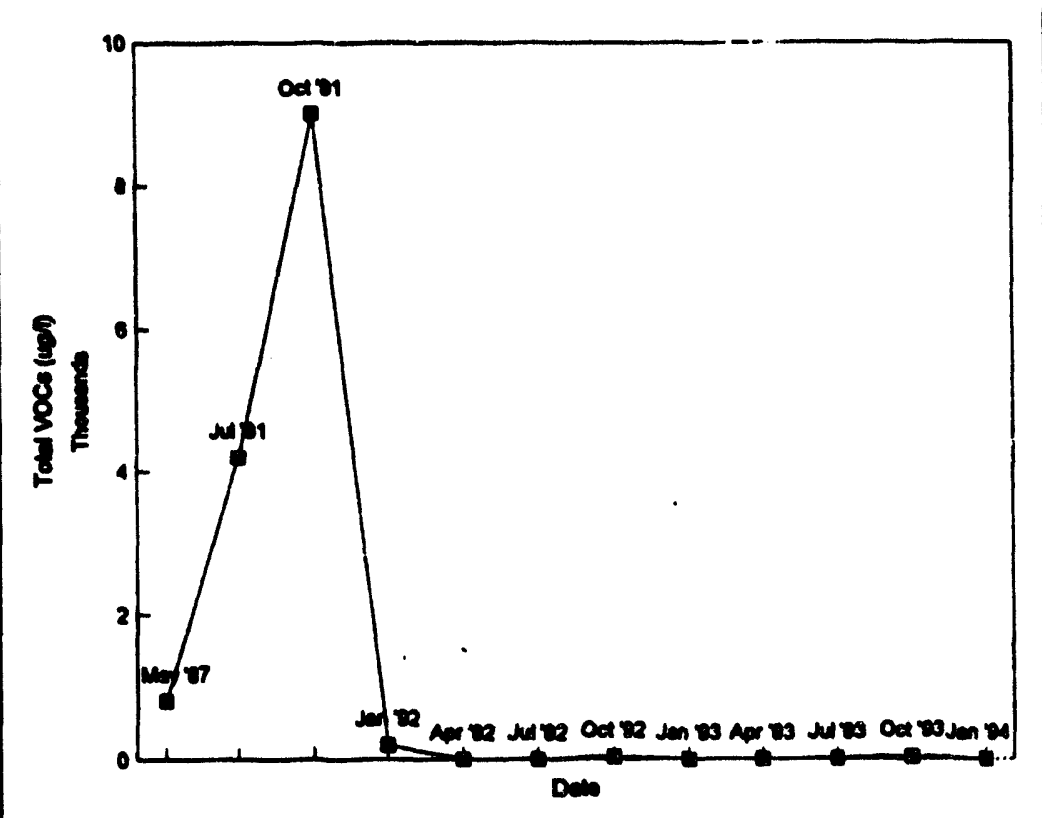

Total vocs (ugl)

Figure 6-14. Chemical Time Series Graph - Monitoring Well NE MW-2D 


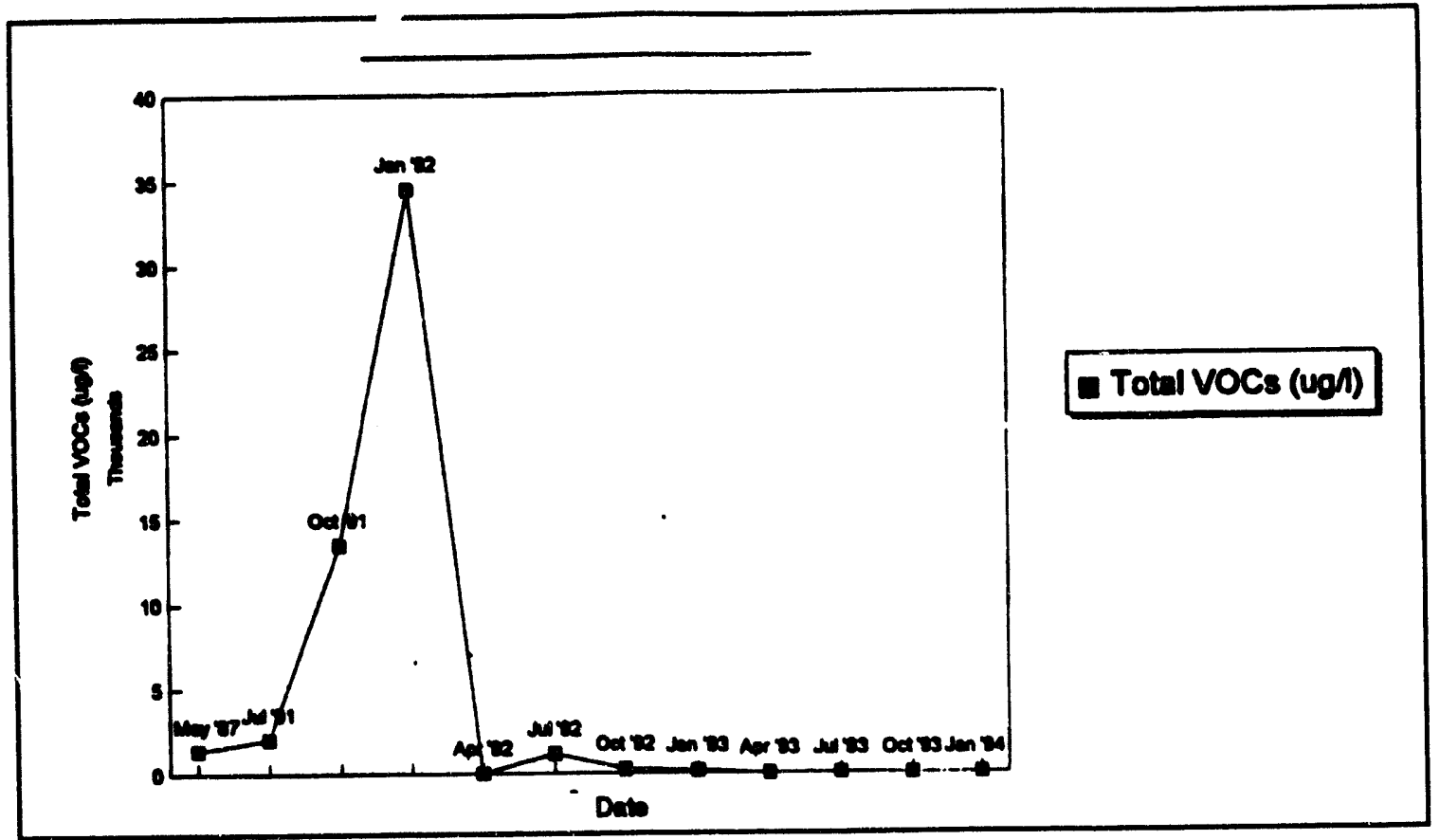

Figure 6-15. Chemical Time Series Graph - Monitoring Well NE MW-21

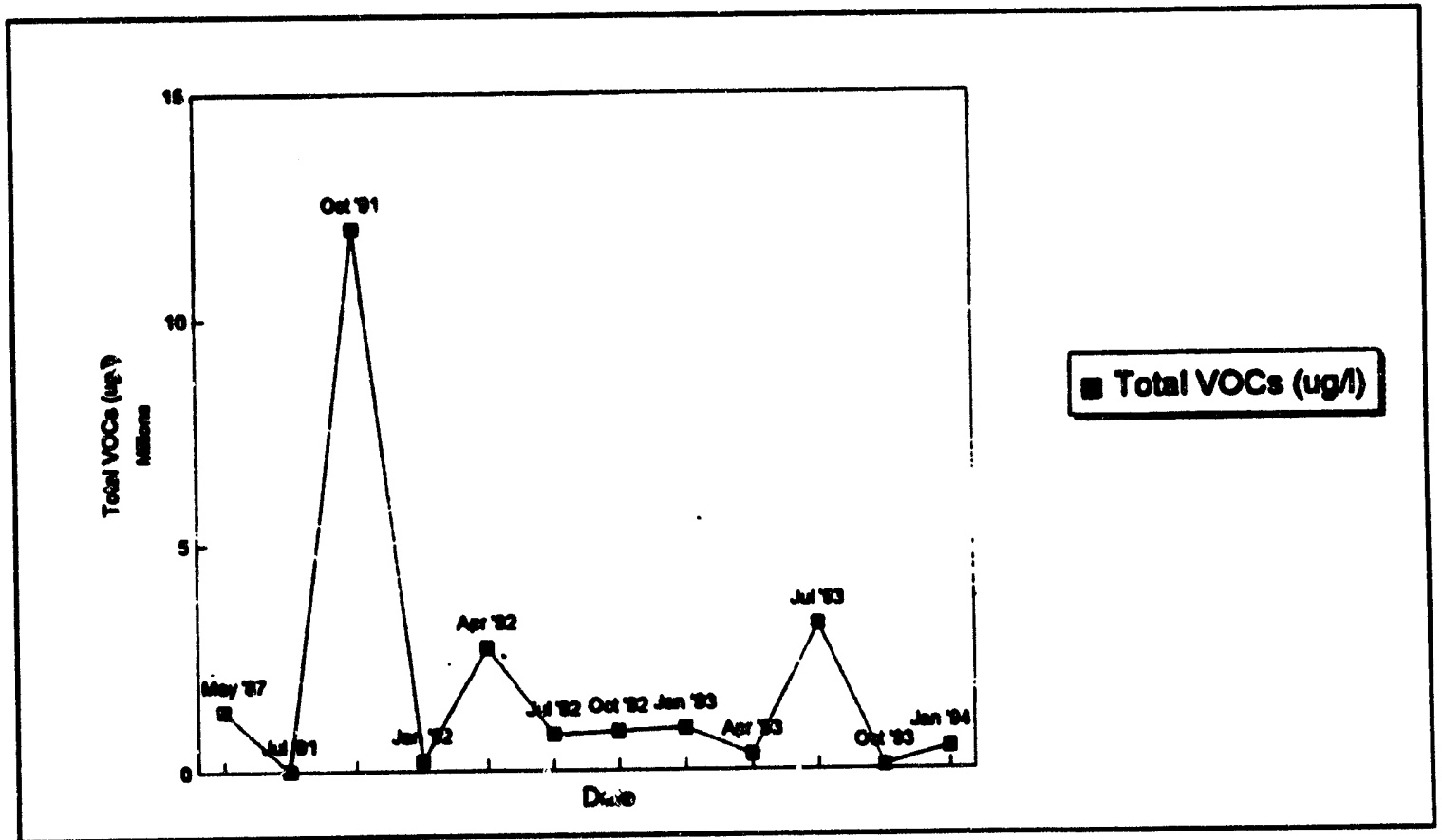

Figure 6-16. Chemical Time Series Graph - Monitoring Well NE MW-2S 


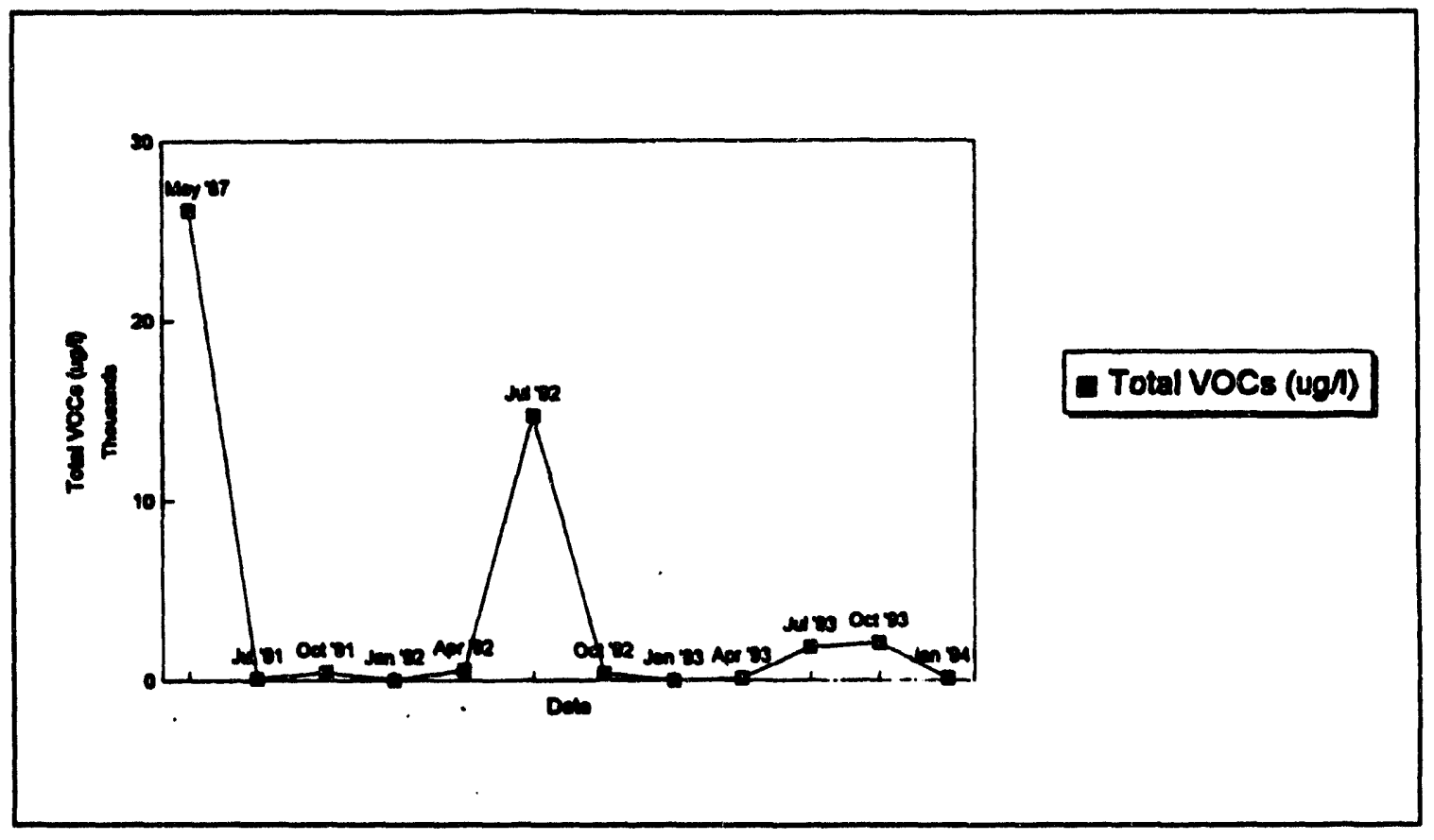

Figure 6-17. Chemical Time Series Graph - Monitoring Well NE MW-3

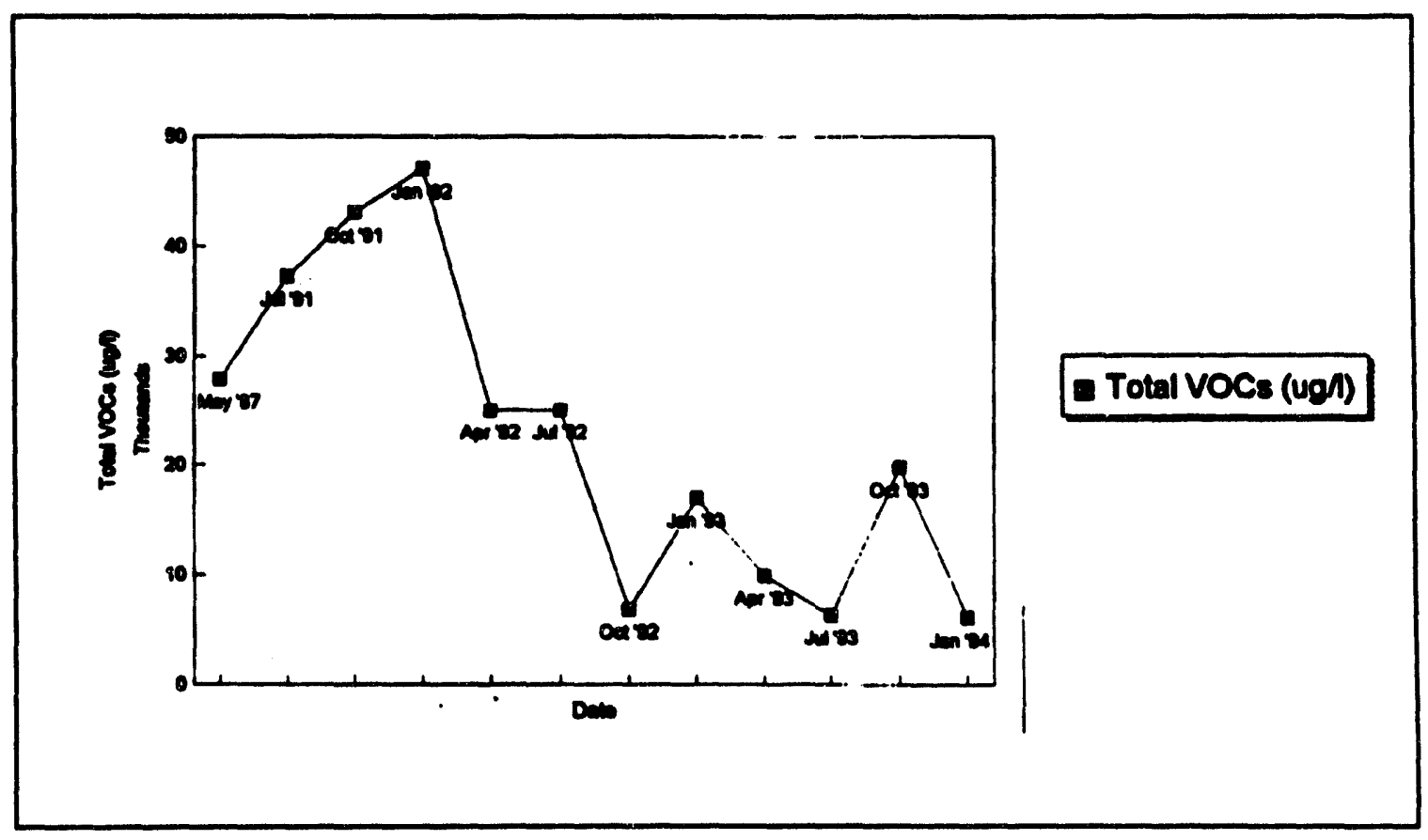

Figure 6-18. Chemical Time Series Graph - Monitoring Well NE MW-4

One potential new SWMU was identified during 1992. Notification of this potential SWMU, the West Fenceline Area, was made by the Pinellas Plant to EPA in May 1992. Pursuant to this notification, an RFA Plan was developed and 
submitted in July 1992, and approved in September 1992. A comprehensive investigation which employed a subsurface hydrocone survey was conducted at this site. The results indicated limited contamination in the surficial aquifer. The plant submitted an RFA report, which included RFI information, in November 1992 to the EPA for their review and approval. In August 1993, the Pinellas Plant HSWA Permit was modified to include the West Fenceline Area.

The Pinellas Plant submitted a CMS plan in November 1993 to the EPA for the West Fenceline Area. Low levels of vinyl chloride in the groundwater near a former materials storage area has migrated to facility boundary. An air sparging and vapor extraction system is proposed for installation under interim measure status.

The implementation of interim corrective measures at the plant is consistent with EPA's goal for the RCRA Corrective Action Program. In EPA's draft Corrective Action Rule, the agency states, "One of the agency's overriding goals in managing the corrective action program will be to expedite cleanup results by requiring (taking) sensible early actions to control environmental problems on an interim basis." This goal is also consistent with the DOE's commitment to the environment; that is, addressing environmental issues in an efficient and thorough, yet cost-effective manner.

Figure 6-19 shows the cumulative volatile organics and groundwater removed from the restoration sites since May 1990. During 1993, total removal of volatiles and groundwater continued to increase, while at the same time, the total concentration of contaminant has shown a general decline. These data will provide valuable insight during planning of final corrective measures. 


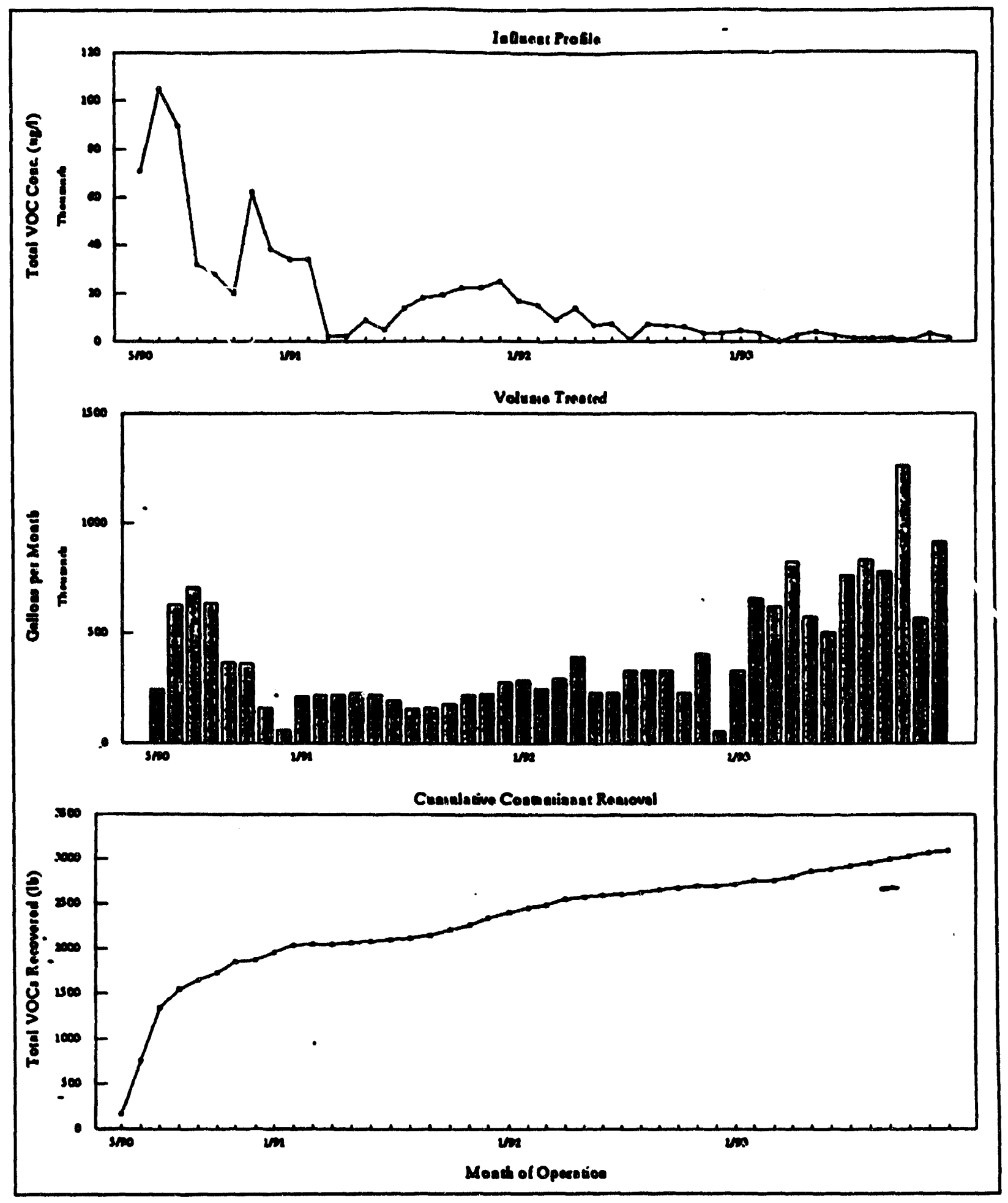

Figure 6-19. Recovery of VOCs in Pinellas Plant Groundwater Treatment System Since May 1990 
This page left blank intentionally. 


\subsection{QUALTTY ASSURANCE}

DOE 5400.1, General Environmental Protection Program, requires that a QA program consistent with the requirements of DOE 5700.6, Quality Assurance, be established covering each element of the environmental monitoring and surveillance programs commensurate with its nature and complexity. Requirements for QA programs at the Pinellas Plant are defined in GOP J.1.07, General Operations Quality Assurance, and in MMSC-QPP-0030, Quality Assurance Program for General (Non-Weapons) Operations.

DOE 5400.1 defines environmental monitoring as the collection and analysis of samples or direct measurements of environmental media. Environmental monitoring consists of two major activities: effluent monitoring and environmental surveillance.

The QA program for environmental monitoring at the plant is documented by MMSC-QPP-0028, Quality Program Plan for Environmental Monitoring. This program provides for the management, performance, assessment, and continuous improvement of environmental monitoring activities. This QA plan, specific to environmental monitoring activities, is consistent with and supplemented by the Quality Assurance Project Plan for Radionuclide Emissions, MMSC-EHS-0039; the Quality Program Plan for Environmental, Safety \& Health Programs, MMSC-QPP-0033; the Quality Program Plan for Environmental Restoration Programs, MMSC-QPP-0049; the Quality Program Plan for NEPA, MMSC-QPP-0048; and the Quality Assurance Project Plan for the Meteorological Monitoring Station, MMSC-QAP-93120.

Sampling and analysis programs not covered by the Quality Program Plan for Environmental Monitoring are regulated by other QA program plans. Groundwater monitoring conducted at the 4.5-Acre Site is performed under the auspices of the FDEP through the approved Comprehensive Quality Assurance Plan, 900402G. Sampling and analysis activities performed on SWMUs of the Miscellaneous Sites are performed under the auspices of the EPA through an approved Site Specific Quality Assurance Project Plan and an RFI.

The Environmental Monitoring Program is defined and controlled through the issuance of Specialty Components Environmental Management Procedures. The Specialty Components Environmental Management Procedures are the governing documents for radiological and non-radiological environmental monitoring activities. These technical procedures for sampling and analysis programs are consistent with EPA methodologies and are reviewed and approved in accordance with EM-7.02, Preparation and Control of Environmental Monitoring Procedures. These documents are controlled using numbered procedure manuals. The documents are maintained by the Technical Support Department in accordance with sitewide document control procedures that include unique issue numbers, document identification, numbered pages, distribution records, revision tracking and a system for filing master copies.

Environmental Protection Specialists generate or modify Specialty Components Environmental Management procedures. New or modified procedures must undergo management review and approval prior to issuance and must be controlled through the sitewide document control system. Minor changes to documents such as inconsequential 
editorial corrections do not require the same review and approval as the original documents; however, it is the responsibility of the Specialty Components Environmental Management Procedure Coordin.ator to make this determination, as identified in EM-7.02.

The Specialty Components Environmental Management Procedure Coordinator reviews each Specialty Components Environmental Management procedure annually to ensure accuracy. Any deviation from the provisions of the procedure must be approved by the Director-Environmental Management or his/her delegated representative.

Each environmental monitoring sample is listed on a Chain-of-Custody record. Assurance for sampling integrity begins with the sample collector by the initiation of the Chain-of-Custody Record as required by Specialty Components Environmental Management Procedure EM-6.01, Sample Custody Procedure, and continues with each person having physical custody of the sample. The document remains with the sample(s) at all times until the laboratory analysis is complete, and it is maintained as a permanent attachment to the analytical report. Once completed, the Chain-of-Custody Record is an accountable document and is maintained and protected as a QA record. Training in sample custody protocol is provided to users by the Training and Education Programs organization as requested by Environmental Management.

\subsection{Nonradioactive Emuent}

Plant personnel collect and analyze effluent from the Pinellas Plant IWNF discharge to the PCSS to maintain compliance with the Pinellas County Industrial Wastewater Discharge Permit 018-IE, effective August 28, 1989. Plant utilities operators collect wastewater samples using sample collection instructions provided by Environmental Management for inclusion into utilities operating procedures. Prior to sample collection, the utilities operators undergo "Water Sample Collection Training and Assessment," a performance-based training plan developed with the Training and Education Programs organization. This training ensures that the trainee has the appropriate water sample collection skills. Field blank(s) and field duplicate(s) are collected during sampling to evaluate the precision of the sampling technique and to detect any possible field contamination.

Plant personnel collect wastewater samples for metals, cyanide, BOD, and TSS for analysis per EM-3.02, Tritium and Chemical Constituents in Wastewater Discharged to the PCSS. All samples are submitted to the Pinellas Plant Chemical Technology-Analytical and Radioanalytical Laboratories for analysis. Chemical Technology is certified by the State of Florida for environmental water analyses performed in support of PCSS compliance. The sampling schedule and QA sampling frequency requirements are listed in Tables 7-1 and 7-2. 
Table 7-1. Wastewater Sampling Schedule

\begin{tabular}{|c|c|c|c|c|}
\hline Wastestream & Tritium & Metals & BOD \& TSS* & Cyanide \\
\hline Sanitary & Daily & $* *$ & $* *$ & *ndustrial \\
\hline Daily & $\begin{array}{c}\text { 2nd workday } \\
\text { of week }\end{array}$ & $\begin{array}{c}\text { 1st Wed. of } \\
\text { month }\end{array}$ & $\begin{array}{c}\text { 2nd workday of } \\
\text { month }\end{array}$ \\
\hline Combined & Daily & $\begin{array}{c}\text { 2nd workday } \\
\text { of week }\end{array}$ & $\begin{array}{c}\text { 1st Wed. of } \\
\text { month }\end{array}$ & $\begin{array}{c}\text { 2nd workday of } \\
\text { month }\end{array}$ \\
\hline *Separate samples & \multicolumn{4}{|c|}{ *ot Required } \\
\hline
\end{tabular}

Table 7-2. QA Sample Frequency Requirements

\begin{tabular}{|l|l|l|}
\hline Parameter & Blank Frequency & Duplicate Frequency \\
\hline Tritium & 2/Week (Tues. \& Thurs.) & 2/Week (Tues. \& Thurs.) \\
\hline Metals & Weekly & 2/Month \\
\hline BOD \&.TSS* & ** & ** \\
\hline Cyanide & 1/Month & 1/Month \\
\hline "Separate samples & \multicolumn{2}{|l}{ *Not Required } \\
\hline
\end{tabular}

The laboratory analyzes the samples in accordance with 40 CFR 136, specified by the PCSS permit. The Pinellas Plant Chemical Technology Laboratories are responsible for the QA associated with this work. To assure quality of analytical performance, both precision and accuracy are monitored in all quantitative analytical measurements through the analysis of duplicate and spiked samples as designated in the Quality Assurance Plan for Wastewater Analyses, MMSC-EM-93068.

\subsection{Radioactive Emuent and Monitoring}

Effluent from the plant IWNF is collected daily for tritium analysis as listed in Table 7-1. Process wastewaters contained in Health Physics holding tanks are sampled and analyzed for tritium prior to discharge to the IWNF and, ultimately, the PCSS. One field blank and field duplicate are collected monthly during the sampling event. Samples are collected by the utilities operators using sampling instructions provided by Environmental Management.

Surface waters both on-site (East, West, and South Ponds) and off-site at 26 locations are monitored for tritium. Ponds are sampled weekly by the utilities operators. QA samples are collected with a frequency of one field blank and one duplicate for each sampling event. Off-site surface waters are collected quarterly by a field services subcontractor using Procedure EM-4.02, Tritium in Off-Site 
Surface Waters. A minimum of one field blank and one field duplicate are collected each day; a minimum of three field blanks and three duplicates are collected for the set.

Environmental monitoring for tritium in air, conducted both on- and off-site, is discussed in Section 4.0 and is performed in accordance with EM-1.04, Tritium in Air On- and Off-Site Ambient Monitoring Stations. Preweighed silica gel columns provided by the Radioanalytical Laboratory are connected to the sample trains and are collected monthly by a field services subcontractor and returned to the laboratory.

Plutonium is monitored in air and soil, both on- and off-site. Air filters are collected bimonthly from four on-site locations and five off-site locations. Soil samples are collected annually from two of fourteen on-site locations and four of sixteen off-site locations on a rotating basis. The samples are collected by a field services subcontractor in accordance with EM-2.02, Plutonium in Air, On- and Off-Site Environmental Monitoring, and EM-5.01, Plutonium in Soil, On- and Off-Site Environmental Monitoring.

All radiological analyses are performed by the plant Chemical Technology-Radioanalytical Laboratory. Procedures are based on methods specified and approved by regulatory agencies. The laboratory is responsible for the quality assurance aspects of these analyses, as defined in NDPP-QPP-0025, Quality Program Plan for the Environmental Chemistry Laboratory.

\subsection{Data Management}

Each Environmental Monitoring Procedure delineates the responsibilities for review of the analytical data and data handling. The responsible Specialist-Environmental Protection retrieves, reviews, validates, and tracks and trends the data, and initiates corrective action as appropriate. Anomalous data is addressed as prescribed by EM-7.05, Treatment of Anomalous Data. As specified in each applicable procedure, the monitored parameter is resampled to verify the data. An investigation is initiated to determine the root cause to prevent recurrence.

\subsection{Proficiency Testing Programs}

The plant participates in proficiency testing programs using spiked samples provided by governmental agencies to provide a quantitative measurement for evaluating internal and external laboratories in the analysis of environmental monitoring samples. The internal plant laboratories participate in third-party QA sample programs as defined in EM-7.03, Administration of Third-Party Quality Assurance Samples. A summary of the Third-Party Quality Assurance Program is listed in Table 7-3. The Environmental Oversight \& Quality Assurance function of ES\&H administers the programs for Environmental Management to ensure independent verification of laboratory activities. 
Table 7-3. Third-Party Quality Assurance Program Summary

\begin{tabular}{|c|c|c|c|c|}
\hline $\begin{array}{l}\text { Samples } \\
\text { Provided By }\end{array}$ & Sample & Analyals & Proquency & $\begin{array}{l}\text { Plant } \\
\text { Laboratory }\end{array}$ \\
\hline$\overline{D O E}$ & EML*Soll & Plutonium & Semiannually & Radioanalytical \\
\hline DOE & EML Water & $\begin{array}{l}\text { Plutonium } \\
\text { Uranium }\end{array}$ & $\begin{array}{l}\text { Semiannually } \\
\text { December }\end{array}$ & Radioanalytical \\
\hline DOE & EML Air Filters & Plutonium & Semiannually & Radioanalytical \\
\hline DOE & $\begin{array}{l}\text { EML H-3 in } \\
\text { water }\end{array}$ & Tritium & Semiannually & Radioanalytical \\
\hline EPA & $\begin{array}{l}\text { EMSL** } \mathrm{H}-3 \text { in } \\
\text { water }\end{array}$ & Tritium & Semiannually & Radioanalytical \\
\hline EPA & $\begin{array}{l}\text { EMSL-LV Air } \\
\text { Filter }\end{array}$ & Gross Alpha & Annually & Radioanalytical \\
\hline $\begin{array}{l}\text { Analytical } \\
\text { Products } \\
\text { Group, Inc. }\end{array}$ & $\begin{array}{l}\text { P.E.T.*n" } \\
\text { Standards }\end{array}$ & BOD, TSS & Semiannually & Analytical \\
\hline $\begin{array}{l}\text { Analytical } \\
\text { Products } \\
\text { Group, Inc. }\end{array}$ & P.E.T. Standards & Metals, cyanide & Semiannually & Analytical \\
\hline \multicolumn{5}{|c|}{$\begin{array}{l}\text { "Environmental Measurements Laboratory } \\
\text { * Environmental Monitoring Systems Laboratory - Las Vegas } \\
\text { ** Proficiency Environmental Testing (P.E.T.) Program }\end{array}$} \\
\hline
\end{tabular}

The Radioanalytical Laboratory participates in radiological programs sponsored by the DOE Environmental Measurements Laboratory and EPA's Environmental Monitoring Systems Laboratory-Las Vegas. Participation includes the semiannual Environmental Measurements Laboratory (EML) Quality Assessment Program; the annual EMSL-LV Air Filter Performance Evaluation Study; and the semiannual Tritium in Water Performance Evaluation Study.

Nonradiological QA samples are submitted to the plant's Analytical Laboratory semiannually. These samples, supplied by Analytical Products Group, Inc., are part of the Proficiency Environmental Testing (P.E.T.) Program, an interlaboratory QA program designed to allow participating laboratories to evaluate their performance against that of other facilities. The program is based on analysis of unknown standards at two levels and is comparable to the EPA's performance evaluation programs.

A summary of the results of analysis of spiked samples provided by Government Third-Party Quality Assurance Programs is listed in Tables 7-4 and 7-5. Results were outside acceptable limits for one event: DOE EML, June 1993, Air Filter for Plutonium 238 and Water Samples for Plutonium 238 and 239. The analyses for Pu-238 and Pu-239 in water were performed on two sample aliquots yielding repeatable but low results. These samples were run simultaneously. It should be noted that the plant Radioanalytical Laboratory does not perform routine 
plutonium analyses on water. The analyses of plutonium in air filters were also the result of two preparations run concurrently. The samples yielded corresponding values. However, the data reported for Pu-238, however, was twice the EML value, while the data for Pu-239 was half the EML value. The source of error has not been determined. Future sample aliquots will be handled separately to maximize preparation error detectability.

Table 7-4. 1993 Results of Analysis of Spiked Samples Provided by Government Third-Party Quality Assurance Programs

\begin{tabular}{|c|c|c|c|c|c|}
\hline Arongy & Dato & Sample & Anolyels & Reported & Actunal \\
\hline$\overline{\mathrm{DOE}}$ & June & EML*Air & Pu-238 & $0.770 \mathrm{E}-01 \%$ & 0.363E-01 Bq/filter \\
\hline$\overline{D O E}$ & June & EML Air & Pu-239 & $0.132 \mathrm{E}-01$ & 0.234E-01 Bq/filter \\
\hline DOE & June & EML Soil & Pu-239 & $0.916 \mathrm{E}+01$ & $0.116 \mathrm{E}+02 \mathrm{~Bq} \mathrm{~kg}$ \\
\hline DOE & June & EML Water & H-3 & $0.102 E+03$ & $0.970 E+02 \mathrm{~Bq}^{-1}$ \\
\hline DOE & June & EML Water & Pu-238 & $0.211 \mathrm{E}+00^{*+*}$ & $0.494 \mathrm{E}+00 \mathrm{~Bq} \mathrm{~L}^{-1}$ \\
\hline DOE & June & EML Water & Pu-239 & $0.141 \mathrm{E}+00^{* * *}$ & $0.828 \mathrm{E}+00 \mathrm{~Bq} \mathrm{~L}^{-1}$ \\
\hline DOE & Dec. & BML Air & Pu-238 & $0.105 E+00$ & $\begin{array}{l}0.129 \mathrm{E}+00 \\
\text { Bq/filter }\end{array}$ \\
\hline DOE & Dec. & EML Air & Pu-239 & 0.650E-01 & $\begin{array}{l}\text { 0.800E-01 } \\
\text { Bg/filter }\end{array}$ \\
\hline DOE & Dec. & EML Soil & Pu-239 & $0.209 \mathrm{E}+01$ & $0.152 \mathrm{E}+01 \mathrm{~Bq} \mathrm{~kg}$ \\
\hline DOE & Dec. & EML Water & H-3 & $0.258 \mathrm{E}+03$ & $0.270 \mathrm{E}+03 \mathrm{~Bq} \mathrm{~L}-1$ \\
\hline DOE & Dec. & EML Water & Pu-238 & $0.113 \mathrm{E}+01$ & $0.114 \mathrm{E}+01 \mathrm{~Bq} \mathrm{~L}^{-1}$ \\
\hline DOE & Dec. & EML Water & Pu-239 & $0.343 E+00$ & $0.338 \mathrm{E}+00 \mathrm{~Bq} \mathrm{~L}^{-1}$ \\
\hline$\overline{D O E}$ & Dec. & EML Water & U-234 & $0.755 E+00$ & $0.106 \mathrm{E}+01 \mathrm{~Bq} \mathrm{~L}^{-1}$ \\
\hline$\overline{D O E}$ & Dec. & EML Water & L1.238 & $0.788 \mathrm{E}+00$ & $0.108 E+01 \mathrm{~Bq} \mathrm{~L}^{-1}$ \\
\hline EPA & Aug. & $\begin{array}{l}\text { EMSLLL" } \\
\text { * Air }\end{array}$ & Gross Alpha & $\begin{array}{l}19.0,18.0, \\
17.0^{2}\end{array}$ & $19.0 \mathrm{pCi} / \mathrm{filter}$ \\
\hline EPA & June & $\begin{array}{l}\text { EMSLLLV } \\
\text { Water }\end{array}$ & H-3 & $\begin{array}{l}9660.0, \\
9590.0,9490.0\end{array}$ & $9844.00 \mathrm{pCl} / \mathrm{L}$ \\
\hline EPA & Nov. & $\begin{array}{l}\text { EMSLLV } \\
\text { Water }\end{array}$ & H-3 & $\begin{array}{l}6990.0, \\
6700.0,7050.0\end{array}$ & $7398.0 \mathrm{pCi} / \mathrm{L}$ \\
\hline & 1 & 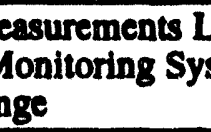 & & & \\
\hline
\end{tabular}




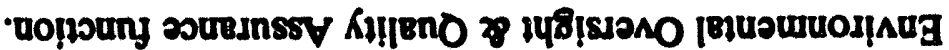

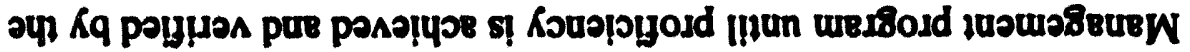

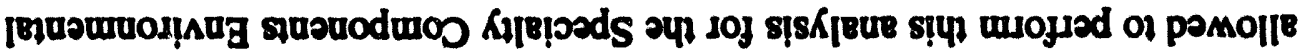

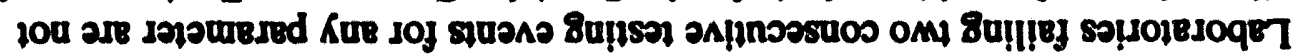

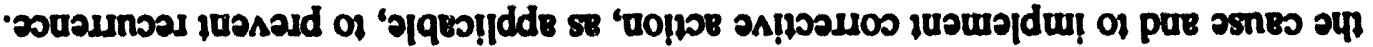

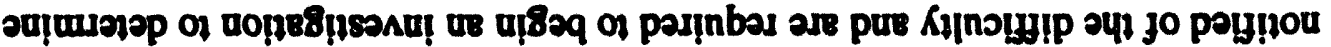

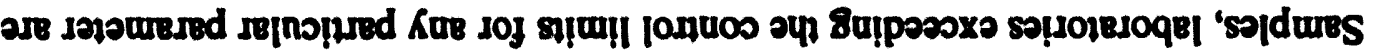

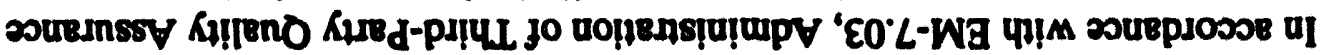

\begin{tabular}{|c|c|c|c|c|c|}
\hline $00 \angle 2 \angle 28$ & 000.961 & $m 8$ & SEt & 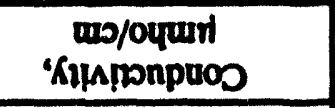 & \\
\hline LIS'I & 6SLO & E8. $\tau$ & $9 \angle 8^{\circ} 0$ & T/8w 'splusko & \\
\hline 096.III & $080^{\circ} \angle 8$ & tor & 962 & Toin suz & \\
\hline OLLISZI & $0<6 \angle I$ & EZI & $L L I$ & Torl 'malis & \\
\hline $060 \% 201$ & $006 \Omega$ & DOI & $\tau \Omega$ & $2 / 8 H$ 'TOXIN & \\
\hline $029^{\circ} 2$ & 0650 & $6<2$ & SLSOO & ZBA Kmonow & \\
\hline 006522 & $026 \Omega$ & 822 & sEz & Torr pert & \\
\hline 06L'I62 & out'os & 582 & ZEE & 2/in 'seddos & \\
\hline OEI'LOI & $0.59^{\circ} \Omega$ & OII & $0 . \varepsilon Z$ & Tor 'mnimasp & \\
\hline OSLELI & OBLIL & $\varepsilon<I$ & g.tI & 28H 'unjupps & \\
\hline $009^{\prime} \angle 92$ & 00265 & ESZ & EIE & T/8m 'SSL & \\
\hline $000^{\circ} 80$ & OOE'TOL & ESS & 801 & T/80 'cog & 'AON \\
\hline I9S2 & $2 E \nabla^{\circ} 0$ & $\nabla L Z$ & E90.0 & T/8m 'oppurko & \\
\hline $000 \% 661$ & $098^{\circ} 62$ & E6I & $L 62$ & $\mathrm{~T} 8 \mathrm{A1}$ suz & \\
\hline 000'S8E & ON6SE & $08 \varepsilon$ & $\angle 82$ & TBr 'malls & \\
\hline oot'2sI & OLOOC & 801 & I0E & ToH TOYOIN & \\
\hline OBS'E & OLO'I & $\angle S E$ & $\angle 9^{\circ} T$ & TAH Kmoson & \\
\hline $00 \angle 8 \angle Z$ & ostec & 892 & g.te & Torl pen & \\
\hline 009'ISI & OSL'SL & OSI & 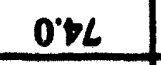 & Zorl soddos & \\
\hline $0068 \angle 2$ & orea & $s L z$ & $8 \cdot 12$ & 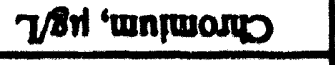 & \\
\hline $00 E \angle D I$ & 01685 & 81 & 9205 & Tort 'unfurpes & \\
\hline $000^{\circ} \angle E 2$ & $00 \angle O C L$ & 912 & $\angle 29$ & Tour 'SSI & \\
\hline $099^{\circ} 9$ & $000^{\circ} \times 2$ & $S t^{\prime} 9$ & 991 & $2 / 84060$ & RBN \\
\hline $2 \operatorname{pan}$ & I PAn & $2 \mathrm{par}$ & $I P A M$ & \multirow[t]{2}{*}{ pupans IIId } & \multirow[t]{2}{*}{0300} \\
\hline & prapor & & paprodor: & & \\
\hline
\end{tabular}

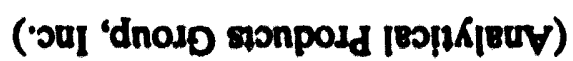

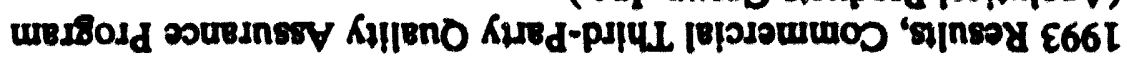




\subsection{OA Pmomm for Meteomlopy Station}

The Quality Assurance Project Plan for the Meteorological Monitoring Station, MMSC-QAP-93120, requires scheduled inspection, maintenance, and calibration of the meteorological instruments and data acquisition system. The plan specifies the requirements for trending on-site data and comparing the results with local National Weather Service data. The important objective of the Quality Assurance analysis is to ensure the accuracy of the climatological data used to support the radiological effluent monitoring and environmental surveillance program.

Data acquired by the Pinellas Plant meteorological station over the thirteen-month period from September 1992 to September 1993 was analyzed by a consultant based on criteria suggested in the "On-Site Meterological Program Guidance for Regulatory Modeling Applications" (EPA, Revised 1993). Overall, the study demonstrated that the meteorological measurements are in compliance with the requirements described in the DOE/EH-0173T Regulatory Guide, DOE 5700.6, 5400.5 , and 5400.1 .

\subsection{Audit Progmm}

The Environmental Oversight \& Quality Assurance function of the ES\&H Division provides independent oversight of Environmental Management activities in accordance with GOP K.2.11, Environmental Oversight. Compliance audits/reviews and other assessments of line operations are conducted to ensure compliance with environmental laws, regulations, requirements, permits, DOE Orders, Specialty Components command media, and Martin Marietta Corporate Environmental Management policies and procedures. Quality audits and surveillances of laboratories and other organizations performing work, both field and analytical, in support of the Specialty Components Environmental Management Program are defined by EM-7.04, Administration of Environmental Monitoring Audit Program. Laboratories are audited annually to evaluate their technical capabilities and the adequacy of their QA programs.

Auditing activities are accomplished using the practices set forth in Standard Operating Procedure (SOP) K.2.11-1, Environmental Oversight Audit Program Practices. An audit report is generated and any finding or notable deficiency requires a written response from the auditee along with a corrective action plan. Follow-up is conducted to verify that the corrective action is applicable and effective. These verification activities are documented, protected, and maintained as QA records. 


\subsection{REFERENCES}

1. Pinellas Plant Environmental Monitoring Plan, MMSC-EM-0012, April 1994.

2. DOE 5400.1, General Environmental Protection, June 1990

3. DOE Order 5400.5, Radiation Protection of the Public and the Environment, June 5, 1990.

4. DOE 5484.1, Environmental Protection, Safety and Health Protection Information Reporting Requirements, October 1990

5. "Data Printout of Tornados in Florida, 1950-1980," National Severe Storms Forecast Center, National Weather Service, U. S. Department of Commerce, Kansas City, MO, March 1981.

6. "Seismic Risk Studies in the United States," S. T. Algermissen, Proceedings of the Fourth World Conference on Earthquake Engineering, Vol. 1, Santiago, Chile, 1969.

7. National Wetland Inventory, Fish and Wildlife Service, U. S. Department of the Interior.

8. 40 CFR Part 61 Subpart H, National Emission Standards for Emissions of Radionuclides Other than Radon from Department of Energy Facilities.

9. Pinellas Plant Annual Site Environmental Report for Calendar Year 1992, MMSC-ESH-93035, June 1993.

10. Air Emissions Construction Permit, AC52-206678, January 7, 1993.

11. Industrial Wastewater Discharge Permit No. 018-IE, dated August 28, 1989.

12. National Categorical Pretreatment Standards, Metal Finishing Category, 40 CFR 433.

13. Pinellas County Ordinance 91-26, dated April 16, 1991.

14. Environment, Safety and Health Tiger Team Assessment of the Pinellas Plant, U. S. Department of Energy, DOE/EH-0126, May 1990.

15. Pinellas Plant Final Action Plan, Supplement 1, ES\&H Assessment of Pinellas Plant, Largo, Florida, NDPP-OSP-0070

16. Final Action Plan Response to Defense Programs, February 1992 Technical Safety Appraisal (TSA), MMSC-OSP-0118.

17. Pinellas Plant Final Action Plan to Defense Programs, February 1992 Technical Safety Appraisal (TSA), MMSC-OSP-93052.

18. Pinellas County Sewer Use Ordinance No. 91-26, dated April 16, 1991.

19. Environmental Monitoring Procedures Manual For Environmental Management, latest revision. 
20. 40 CFR Part 141, Primary Drinking Water Regulations.

21. "Ionizing Radiation Exposure of the Population of the United States," National Council on Radiation Protection and Measurements, NCRP Report No. 93, Bethesda, MD, September 1, 1987. 


\subsection{DISTRIBUTION}

\section{Pinellas Plant}

Dr. Charles A. Hall, President

Martin Marietta Specialty Components, Inc.

P. O. Box 2908

Largo, FL 34649-2908

Mr. Edward Mayer, Director

Environmental Management

Martin Marietta Specialty Components, Inc.

P. O. Box 2908

Largo, FL 34649-2908

Mr. Charles Biedermann, Manager (14)

Environmental Restoration and Permitting

Martin Marietta Specialty Components, Inc.

P. O. Box 2908

Largo, FL 34649-2908

Ms. Delphine Delaneuville, Manager (5)

Waste Management/Minimization

Martin Marietta Specialty Components, Inc.

P. O. Box 2908

Largo, FL 34649-2908

Pinellas Plant Technical Information Center Martin Marietta Specialty Components, Inc. P. O. Box 2908

Largo, FL 34649-2908

\section{Federal Agencies}

Ms. Patrice Babar, Acting Director

EM-323 Waste Operations

U. S. Department of Energy

Trevion II

Washington, D.C. 20585-0002

Ms. Marilyn Bange, Chief

Waste Management Division

U. S. Department of Energy

Albuquerque Operations Office

Albuquerque, NM 87115
Mr. Carl Froede, Jr.

Remedial Project Manager

Environmental Protection Agency

Region IV

345 Courtland Street, N.E.

Atlanta, GA 30365

Mr. James M. Gaver (2)

U. S. Department of Energy

Savannah River Operations Office

Office of External Affairs

P. O. Box A

Aiken, SC 29801

Ms. Dawn Gillas, Chief

ES\&H and Compliance Branch

U.S. Department of Energy

Pinellas Area Office

P. O. Box 2900

Largo, FL 34649-2900

Ms. Sarah Hartson (40)

Environmental Compliance Engineer

U.S. Department of Energy

Pinellas Area Office

P. O. Box 2900

Largo, FL 34649-2900

Mr. David Ingle

Environmental Restoration Program Manager

U. S. Department of Energy

Pinellas Area Office

P. O. Box 2900

Largo, FL 34649-2900

Mr. William Gunter

Director, Criteria \& Standards Division

Office of Radiation Programs

U. S. Environmental Protection Agency

401 M Street, S. W.

Washington, D.C. 20460

M. Kleinrock, Director (2)

Environmental Compliance Division

U. S. Department of Energy, EM-22

Forrestal Building

1000 Independence Ave., SW

Washington, DC 20585 
Mr. Arthur Linton

Federal Facilities Coordinator

Environmental Protection Agency

Region IV

345 Courtland Street, NE

Atlanta, GA 30365

Mr. R. Hagan (2)

Director, Pinellas/Kansas City

Facility Management Division

U. S. Department of Energy, DP-644

Forrestal Building

1000 Independence Ave., SW

Washington, DC 20585

Mr. Ronald L. Petersen, Chief

Environmental Compliance Bureau

U. S. Department of Energy - SR/ECD

P. O. Box A

Aiken, SC 29802

Mr. Gary Schmidtke

Waste Management Program Manager

U. S. Department of Energy

Pinellas Area Office

P. O. Box 2900

Largo, FL 34649-2900

Ms. G. Schreiner

Manager, Technical Information Program

U. S. Department of Energy

Albuquerque Operations Office

P. O. Box 5400

Albuquerque, NM 87115

Mr. Richard Sena, Director

Environmental Restoration Project Office

U. S. Department of Energy

Albuquerque Field Office

P. O. Box 5400

Albuquerque, NM 87115
C. L. Soden, Director (3)

Environmental Protection Division

U. S. Department of Energy Field Office

Albuquerque Operations Office

P. O. Box 5400

Albuquerque, NM 878115

K. I. Taimi, Director (5)

Office of Environmental Compliance

U. S. Department of Energy, EH-22

Forrestal Building

1000 Independence Ave., SW

Washington, DC 20585

Mr. John H. Hankinson, Jr.

Regional Administrator

Environmental Protection Agency

Region IV

345 Courtland Street, NE

Atlanta, GA 30365

U. S. Department of Energy

Office of Scientific and Technical

Information Center

P. O. Box 62

Oak Ridge, TN 37831

\section{State and Local Agencies}

Dr. Roberta Hammond

Department of Health \& Rehabilitative

Services

1317 Winewood Blvd.

Tallahassee, FL 32399-0700

(Epidemiological Study Contact)

Harlan W. Keaton

Public Health Physicist Manager

Department of Health and Rehabilitative

Services, Bldg. 18

Pine Hills Service Center

Orlando, FL 32868-0069 
Mr. David R. Bilodeau, Director

Pinellas County Emergency Management Administration 400 South Fort Harrison Avenue

Clearwater, FL 34616

Ms. Ginger Wetherhall, Secretary

State of Florida

Department of Environmental Protection

Twin Towers Office Building

2600 Blair Stone Road

Tallahassee, FL 32399-2400

Dr. Lyle Jarrett, Director

State of Florida

Office of Radiation Control (PD HIR)

1317 Winewood Boulevard

Tallahassee, FL 32399-0700

Mr. Ray Dielman

Public Health Physicist

State of Florida

Health and Rehabilitative Services

Office of Radiation Control

300 31st Street North,

St. Petersburg, FL 33713

Dr. Richard D. Garrity (2)

State of Florida

Department of Environmental Protection

Southwest District Office

3804 Coconut Palm Drive

Tampa, FL 33619-8318

Ms. Martha Gray

Environmental Engineer

Department of Environmental Management

Pinellas County Technical Services Bldg.

440 Court Street

Clearwater, FL 34616

Mr. P. A. Hessling, Director

Pinellas County

Department of Environmental Management

Air Quality Division

16100 Fairchild Drive, Bldg. V-102

Clearwater, FL 33520
Mir. Robert Nave

Division of Emergency Management

1720 South Gadsden

Tallahassee, FL 32399

Mr. Todd Tanberg, Director

Pinellas County Sewer System

310 Court Street

Clearwater, FL 34616

\section{Others}

Mr. \& Mrs. David Akers

9959 82nd Street N

Largo, FL 34647

Ms. Elja Alford

7140 118th Terrace $N$

Largo, FL 34643

Dr. Elaine Anderson

10460 Longwood Dr

Largo, FL 34647

Mr. Chet Askey

456 26th Avenue N

St. Petersburg, FL 33704

Mr. Paul Bahmiller

10319 95th Street N

Seminole, FL 34647

Mr. E. J. Balzart

1597 Pennwood Circle S

Clearwater, FL 34616

Ms. Sandy Barbeau

14989 Cromwell Dr.

Clearwater, FL 34624

Ms. Patricia T. Birnie

2001 83rd Avenue North, \#1252

St. Petersburg, FL 33742-2753

Mr. Joseph D. Borucki

8989 Lynwood Drive

Seminole, FL 34642 
Ms. Mary Brennan

State Representative

District 57

6251 44th Street North, Suite 7

Pinellas Park, Florida 34665

Mrs. J. K Brolon

10671 Andrew Lane

Largo, FL 34647

Mr. Joe Buonfiglio

724 115th Avenue North \#2202

St. Petersburg, FL 33716

Mr. Bob Burk

2960 Tangerine Terrace

Palm Harbor, FL 34684

Mr. Victor Corman

11961 97th Avenue

Seminole, FL 34642

Ms. Karen Jackson Costello

12235 66th Street N

Largo, FL 34643

Mr. Brian Costner

Energy Research Foundation

537 Harder Street

Columbia, SC 29205

Mr. Marshall Coviello

11911 66th Street, Lot 417

Largo, FL 34643

Ms. Gabriele S. Dailey

Dames \& Moore

3204B San Juan Street, West

Tampa, FL 33629

Ms. Judith M. Davis

2867 Whispering Drive S

Largo, FL 34641

Ms. Marion Davis, President

League of Women Voters

St. Petersburg Area

P. O. Box 11775

St. Petersburg, FL 33733
Ms. Kathleen DiViti

11189 Tradewinds Blvd

Largo, FL 34643

Mr. Robert G. Doan

4012 McKay Circle

Largo, FL 34640

Mr. Mark Douglas, Reporter

Channel 10 WTSP-TV

Box 10,000

St. Petersburg, FL 33733

Ms. Helen Doyle

12377 69th Street N

Largo, FL 34643

Mr. Donald R. Drung

2011 Del Betmar

Clearwater, FL 34623

Mr. John Dunbar

Pinellas Review

2575 Granada Circle East

St. Petersburg, FL 33716

Ms. Mamie Durham

League of Women Voters

6021 Sailboat Key, Bldg. \#202D

South Pasadena, FL 33207

Mr. \& Mrs. Paul Ebacher

11666 Tradewinds Blvd

Largo, FL 34643

Mr. Dan Eberts

10021 85th Street $N$

Largo, FL 34647

Ms. Deborah A. Fadool

Knollwoode Civic Association 8045 Cottonwoode Drive

Largo, FL 34643

Mr. Robert Fay

Suncoast Sierra Club

5050 4th St. No., Lot 514

St. Petersburg, FL 33703 
Mr. Don Fisher

Clearwater Greens

12 South Mars Avenue

Clearwater, FL 34615

Ms. Mary Jane Fitzwater 9488 127th Ave., N

Largo, FL 34643

Ms. R. Fornino

409 Bayview Street

Safety Harbor, FL 34695

Ms. Barbara Frances

12256 93rd Street N

Largo, FL 34643

Mr. Reginald Frost

8924 Osprey Lane

Seminole, FL 34647

Mr. William George

9230 136th Way N

Seminole, FL 34646

Ms. Crystal Gildea

9015 109th Terrace N

Largo, FL 34647

Mr. H. S. Gill

Dames \& Moore

4508 Brookwood Drive

Tampa, FL 33629

Mr. Alan Goldstein

Business Writer

St. Petersburg Times

P. O. Box 1121

St. Petersburg, FL 33731

Ms. Peggy Goodale

7232 118th Circle North

Largo, FL 34643
Mr. William Goolet

Manager, Consulting Services

Director, Hazardous Waste Operations

11300 43rd St., North

Clearwater, FL 34622

Ms. Mary Kay Green

10311 95th Street N

Largo, FL 34647

Mr. Terry Griffin

HSW Environmental Consultants

5020 Gunn Hwy., Suite 250

Tampa, FL 33549

Ms. Jane Hammer

120 Carlyle Drive

Palm Harbor, FL 34683

Ms. Pearlie M. Harris

3618 2nd Avenue South

St. Petersburg, FL 33711

Ms. Julia Haveline

7603 Ulmerton, 5A

Largo, FL 34641

Ms. Carol Henry

HSW Environmental Consultants

5020 Gunn Hwy., Suite 250

Tampa, FL 33549

Ms. Frances Hoelper

9400 127th Ave., N

Largo, FL 34643

Ms. Jacalyn Howard

1629 Sandstone Court

Clearwater, FL 34616

Mr. \& Mrs. Harry Howell

7 Elgin Place, \#501

Dunedin, FL 34698

Ms. Monica Hughes

12554 Starkey Road

Largo, FL 34643

Ms. Teresa Hunter

2045 East Bay No. 024

Largo, FL 34641 
Mr. James Jacobs

441 33rd Street $N$

St. Petersburg, FL 33713

Ms. Deborah Janecki

8496 Bardmoor Place

Largo, FL 34647

M. Robert F. Jilek

Pinebrook Estate Homeowners Association 11840 71st Circle North

Largo, FL 34643

Mr. Jerry Kaiser

832 Lakeside Terrace

Palm Harbor, FL 34687

Mr. Berg Kashian

1457 Bluebell NE

Albuquerque, NM 87122

Mr. Fred Kenny

5641 80th Avenue N

Pinellas Park, FL 34665

Mr. David Kiewit

2420 Seneca Court

Palm Harbor, FL 34683

Ms. Catherine Klein

11321 North 50th Street \#19

Tampa, FL 33607

Dr. Richard D. Klein

Manager, Environmental Mgmt. Dpt.

Haliburton/NUS

900 Trail Ridge Road

Aiken, SC 29803

Ms. Mary Kovalsky

7126 118th Terrace North

Largo, FL 34643

Mr. David H. Knowlton, President

Pinellas Economic Development Council 19321 U. S. Highway 19 North

Clearwater, FL 34624
Mr. \& Mrs. Mark Kuhns

1224 Markley Drive

Largo, FL 34640

Mr. \& Mrs. Fred Lair

8931 Merrimoor Blvd E

Seminole, FL 34647

Ms. Sue Landry

St. Petersburg Times

P. O. Box 1121

St. Petersburg, FL 33731

Ms. Fay Law, President

League of Woman Voters

Clearwater/Upper Pinellas County

P. O. Box 6725

Clearwater, FL 34618

Mr. Tony Lester

Route 2, Box 86

Bowling Green, FL 33834

Ms. Susan Maholm

9683 Leeward Avenue

Largo, FL 34643

Mr. Pat Marzulli

322 12th Avenue

Indian Rocks Beach, FL 34635

Ms. Moira McCaughey

South Pinellas Greens

6900 16th Avenue No.

St. Petersburg, FL 33710

Ms. Alex McNeese

903 S Greenwood Avenue

Bldg. 3, Apt. 4

Clearwater, FL 34616

Ms. Verlean Merritt

2689 Pinellas Point Drive South

St. Petersburg, FL 33712

Mr. Ken Mercer

11911 66th St. N

Largo, FL 34643 
Ms. Nancy Millichamp 6680 31st Terrace $N$

St. Petersburg, FL 33710

Ms. Nancy Milligan 8660 Maidstone Court Largo, FL 34647

Mr. Paul Morrison

7825 Tiburon Drive

Largo, FL 34643

Ms. Pamela J. Mosier

Florida Coalition for Peace \& Justice 212 Beach Place \#1

Tampa, FL 33606

Mr. Kenneth Murray

12675 114th Street N

Largo, FL 34648

Ms. Patty Novak

7605 Cumberland Road

Largo, FL 334647

Mr. Ted Page

LLUVIA, Inc.

6822 22nd Avenue N, Room 149

St. Petersburg, FL 33710

Ms. Terry Perkins

Emmanuel Community 6680 31st Terrace North

St. Petersburg, FL 33710

Mr. Matthew Pesce

Pinebrook Homeowners Association

12150 74th Street North

Largo, FL 34643

Mr. John H. Pillis, III 10893 97th Street N

Largo, FL 34643

Mr. Ron Priest

8046 Bayhaven Drive

Seminole, FL 34646
Ms. Penny Rasmussen

Linvatec

9119 Orchid Drive

Largo, FL 34643

Ms. Maura Reedy

1201 Seminole Blvd., \#554

Largo, FL 34640

Mr. Richard Reynolds

NDL Partnership School/Child Development

Center

P. O. Box 2908

Largo, FL 34649

Mr. Daniel W. Rothenberger

14902 Winding Creek Court

Suite 101-C

Tampa, FL 33613

Ms. Eleanor Salkin

Senior Citizen Coalition of Hillsborough

400 East Harrison Street, \#507

Tampa, FL 33602

Mr. \& Mrs. William Sarti

2170 Nolan Drive $S$

Largo, FL 34640

Ms. Pam Scalese

5802 13th Avenue S

Gulfport, FL 33207

Ms. Carol Schaefnocker

ERM - South, Inc.

9501 Princess Palm Avenue, \#100

Tampa, FL 33619

Mr. Robert E. Schweiger

P. O. Box 98

Ozona, FL 34660

Ms. Joanne Shrewsbury

League of Woman Voters

9731 63nd Avenue N

St. Petersburg, FL 33708

Mr. Ron Simonton

9820 121st Street North

Seminole, FL 34642 
Ms. Lisa Simmons

9488 127th Avenue N

Largo, FL 34643

Ms. Cynthia Smith

10266 95th Street N

Largo, FL 34647

Mr. Mike Smutko

System One

4902 Eisenhower Blvd.

Tampa, FL 33634

Mr. John D. Spence 10101 9th Street North

St. Petersburg, FL 33716

Mr. John Stewart

Emmanual Community

2130 Burlington Avenue iv

St. Petersburg, FL 33710

Ms. Sheila Stewart

2130 Burlington Avenue $N$

St. Petersburg, FL 33713

Mr. Jeff Stidham, Reporter

Tampa/Pinellas Tribune 38501 U. S. $19 \mathrm{~N}$

Palm Harbor, FL 34684

Mr. John T. Stimus

PACE Laboratories, Inc.

5460 Beaumont Center Blvd.

Tampa, FL 33634

Mr. Bob Sullivan

Sierra Club, Suncoast Group

P. O. Box 16006

St. Petersburg, FL 33733-6006
Mr. Michael Swann

9400127 th Avenue N

largo, FL 34643

Ms. Deborah Sweeney

8185 83rd Avenue $N$

Seminole, FL 34647

Mr. Jerry Tetro

Trademark Homes

12173 Wild Acres Road

Largo, FL 34643

Mr. Wally Tobin

9253 123rd Avenue N

Largo, FL 34643

Mr. Thomas I. Warren

10008 "B" Pawnee

Tampa, FL 33617

Ms. Jan Welch

Knollwood Village Civic Association

7968 Shadow Run Drive

Largo, FL 34643

Mr. Davis Wogaman

12054 114th Street N

Largo, FL 34648-2543

Ms. Susan Yormark

16216 3rd Street East

Redington Beach, FL 33708

Mr. Doyle Young

VA Medical Center

10000 Bay Pines Blvd

Bay Pines, FL 33504

Ms. Elena A. Zerfas

7133 Danbury Way

Clearwater, FL 34624 

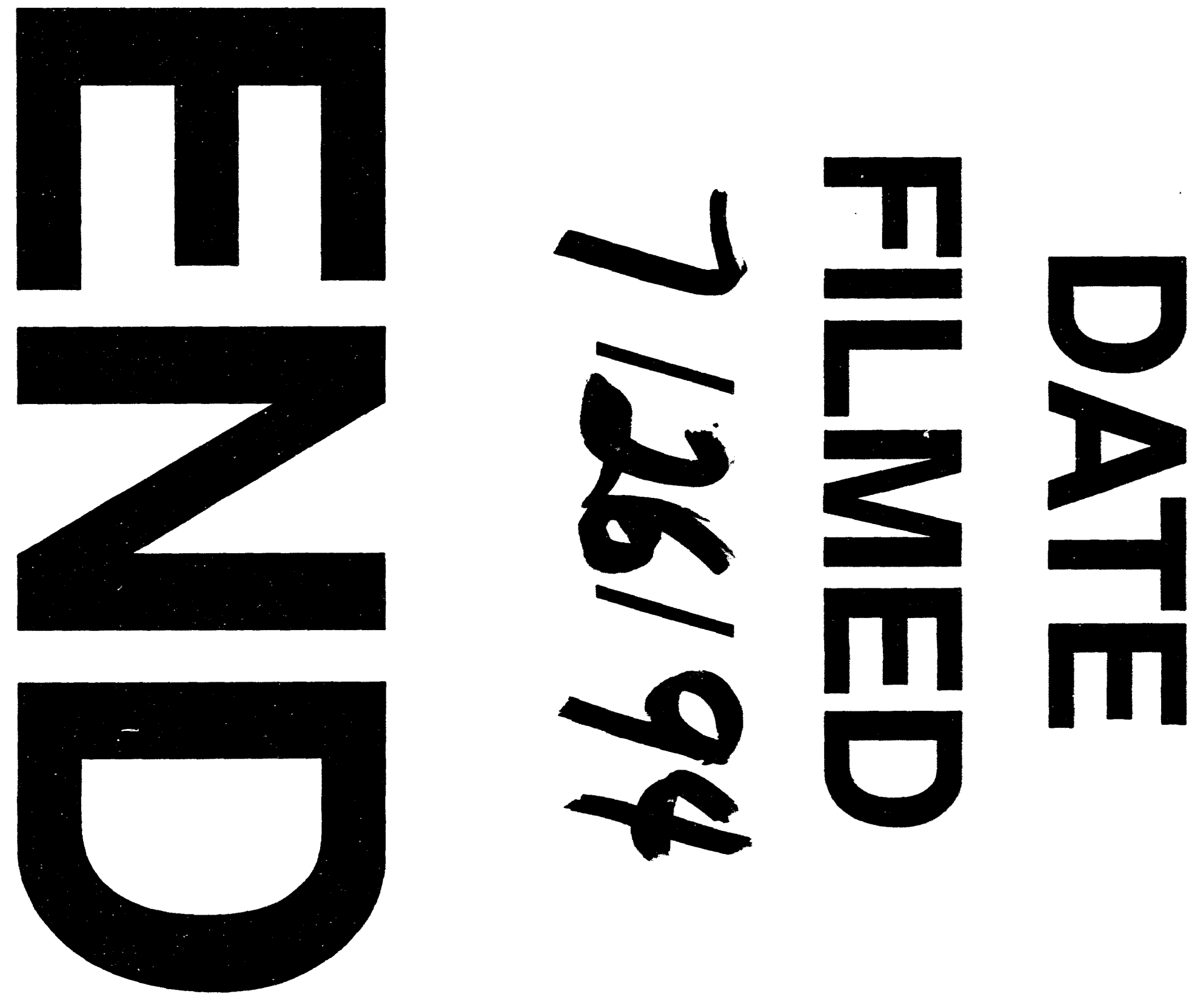
